\title{
El tratado sobre el vestir, calzar y comer del arzobispo Hernando de Talavera
}

\author{
TEREsa de CASTRO *
}

\begin{abstract}
RESUMEN
ABSTRACT

Este trabajo contiene la edición integra y crítica del «Tratado sobre la demasía en el vestir, calzar y comer» escrito por Hernando de Talavera en

1477 en Valladolid y publicado por encargo suyo en Granada alrededor del año 1496. La edición va acompañada de un estudio introductorio y de sus correspondientes indices.

This paper contains the complete edition of the Hernando de Talavera's treaty known as "Tratado sobre la demasia en el vestir, calzar y comer" (Treaty about the excesses in dressing, wearing and eating), written in Valladolid in 1477 and published in Granada around 1496.
\end{abstract}

El presente trabajo tiene como fin principal dar a conocer el texto íntegro del tratado titulado "De la demasía en el vestir y comer...beber y comer" escrito por Hernando de Talavera. En esta introducción ofrecemos algunos datos generales sobre el autor y analizamos con más detenimiento las circunstancias que rodearon la redacción de la obra y sus características formales. Terminanos ofreciendo unas notas sobre las posibles utilidades que un tratado como éste presenta para el investigador medievalista o modernista. El apéndice documental recoge la edición crítica del tratado con sus correspondientes índices toponímico, de materias y onomástico.

\footnotetext{
- Research Centre for the History of Food and Drink. Adelaide University (Australia).
} 


\section{HERNANDO DE TALAVERA}

El fraile jerónimo Hernando de Talavera (1428-1507) fue estudiante y profesor de Filosofía Moral en la Universidad de Salamanca. En agosto de 1466 ingresó en el monasterio jerónimo de San Leonardo de Alba de Tormes, donde pronto adquirió fama de buen religioso. Cuatro años después se lo disputaban para el cargo de prior dos casas, la suya y la de Nuestra Señora del Prado en Valladolid, pero se decantó por esta última; allí permaneció 16 años ejerciendo una importante labor renovadora de la vida monástica con la reimplantación del ora et labora. Alrededor del año 1475 conoció a la princesa Isabel, futura Reina Católica, convirtiéndose pronto en su confesor. Talavera fue el inspirador del programa de reformas político-religiosas emprendidas tras el final de la guerra civil castellana, así como de aquéllas religiosas instauradas a partir del sínodo de Sevilla de 1478. A partir de 1485 ostentó el cargo de obispo de Ávila, destacando una vez más por su proximidad a las primitivas doctrinas de la Iglesia. Tras la conquista de Granada en 1492 ejerció de administrador apostólico del Reino de Granada hasta que en enero de 1493 recibió la bula que lo nombraba arzobispo. Su caída en desgracia empezó a producirse a partir de 1499, coincidiendo con el ocaso personal de la reina lsabel y de sus consejeros políticos. A fines de 1505 fue acusado de hereje pero, a pesar de la dureza del proceso y de las torturas, el papado tomó cartas en el asunto y no aceptó la acusación. Su muerte se produjo el 14 de mayo de 15071.

Fue su trabajo pastoral en Granada el que le hizo uno de los personajes castellanos más controvertidos de la última década del siglo xv. Ello se debió no sólo a la relevancia de su cargo eclesiástico y al hecho de ser el consejero de los Reyes Católicos, sino también a su implicación directa en la política religiosa de los monarcas. Tras la conquista del reino de Granada, los Reyes Católicos iniciaron una política de conversión de los musulmanes que pusieron en manos de Hernando de Talavera. Su "mano blanda", su carácter moderado, la preocupación por los mudéjares y su método centrado en la predicación chocaron con la falta de resultados visibles y con la prisa de los reyes por acelerar el proceso. Ello condujo a su sustitución en 1499 por el cardenal franciscano Francisco Jiménez de Cisneros cuya intransigencia provocó el inicio de la rebelión mudéjar y la posterior conversión masiva y forzosa de esta comunidad. Todo lo dicho contribuyó a la idealización de Talavera frente a su sucesor. De este modo, en la Historia Eclesiástica de Gra-

1 Para ampliar datos sobre la vida de Hernando de Talavera y su labor religiosa en Granada véanse: J. SUBERBIOLA, Real Patronato de Granada. El arzobispo Talavera, la Iglesia y el Estado Moderno. 1486-1516, Granada, 1985; A. FERNÁNDEZ DE MADRID, Vida de Fray Hernando de Talavera, primer arzobispo de Granada, Granada, 1992 y L. Resines, Hernando de Talavera, prior del Monasterio de Prado, Consejería de Educación de la Junta de Castilla y León, 1993. 
nada escrita por Francisco Bermúdez de Pedraza en el año 1638, Talavera aparece casi santificado: se resaltan su sencillez, su austeridad, sus virtudes predicadoras, su accesibilidad, el amor que le profesaba todo el mundo en la ciudad de Granada, etc. ${ }^{2}$.

Hernando de Talavera fue asimismo un prolífico hombre de letras, estando su obra centrada en cuestiones moralistas y ascéticas. Escribió un buen número de tratados, instrucciones y folletos dirigidos tanto a religiosos como a legos. Entre los primeros redactó una instrucción sobre cómo habían de visitarse la iglesias y conventos de monjas; un confesional; un ceremonial, donde se explicaba qué representaban y cuándo se celebraban las distintas ceremonias religiosas; dos oficios sobre la toma de Granada y dos más dedicados a la festividad de San Juan y la Expectación de la Virgen. Dentro de las obras de carácter divulgativo dirigidas a legos tenemos una instrucción hecha a instancia de la condesa de Benavente sobre en qué habian de gastar el tiempo las señoras de título; una especie de cartilla en la que enseñaba la ley cristiana, un tratado contra la murmuración, y la obra que estudiamos aquí. Finalmente, escribió una impugnación en defensa de la fe católica rebatiendo un libro herético publicado en Sevilla y enmendó la Vita Christi de Fray Francisco Ximénes. Gran parte de sus trabajos fueron impresos, ya que Talavera consideraba que la imprenta era un elemento indispensable para difundir con rapidez y precisión su mensaje apostólico. Fue el fundador de la primera imprenta en Valladolid (1480) y cuando llegó a Granada atrajo a la ciudad a los famosos impresores alemanes Meinardo Ungut y Juan Pegnitzer que habian estado trabajando previamente en Sevilla ${ }^{3}$.

\section{EL TRATADO SOBRE LA DEMASÍA EN EL VESTIR, CALZAR Y COMER}

La redacción del texto original se realizó en 1477, cuando Hernando de Talavera era todavía prior del monasterio de Santa María de Prado en Valladolid, mientras que la edición se produjo en los años inmediatamente posteriores a la conquista de Granada, alrededor del año 1496. El hecho concreto que motivó la redacción de esta obra fue la edición en Valladolid de un decreto de excomunión a las mujeres que se vistiesen con gorgera y caderas an-

2 BERmúdeZ, Historia Eclesiástica de Granada, Granada, Universidad de Granada, 1989 (ed. Facsímil de la de 1639), pp. 183 y ss.

3 Una lista detallada de la producción literaria de Talavera se encuentra en FERNÁNDEZ DE MADRID, A.: Vida de Fray Fernando de Talavera, primer arzobispo de Granada. Estudio preliminar e iconografía inédita por F. J. Martínez Medina. Edición de F. G. Olmedo, Granada, 1992, pp. XLIII-LXXVI (edición Facsimil de la original de 1931). 
chas y a los hombres que llevasen camisones con cabezones labrados 4 . El escándalo que este edicto creó entre los intelectuales y hombres letrados de la ciudad motivó la consulta a las autoridades eclesiásticas. Hernando de Talavera respondió por escrito dando su apoyo a la decisión de los religiosos vallisoletanos, para lo cual redactó los capítulos que componen este tratado ${ }^{5}$.

Los argumentos expuestos pretendian dos cosas. Primero, demostrar que los eclesiásticos sí podían dar su opinión sobre el tema de la vestimenta y legislar al respecto. Segundo, demostrarlo de una forma sencilla y comprensible para todo el mundo, sin que faltase el recurso tradicional a los ejemplos bíblicos y a la Patrística. Para ello adoptó el formato de un tratado de moral, examinando la conducta humana bajo el prisma de los mandamientos, los pecados capitales, los sacramentos, la vida de los profetas, los Padres de la Iglesia, los Apóstoles y algunos santos.

No se trata tanto de dirigir la conducta de los fieles recordándoles qué pueden hacer y qué no, como de justificar la supremacia moral y política de la Iglesia en la ordenación de los comportamientos sociales. En los años finales del sigio xv y los primeros del xvi el peso de los principios de la Iglesia en la vida cotidiana era decisivo y no se quedaba sólo en el ámbito de lo teórico. Con todo, la moral impuesta por la Iglesia no fue la única, ya que alternó y se combinó con la propuesta por las clases sociales dominantes. A lo largo de la Edad Media se había ido produciendo un proceso de laicización, de modo que la incontestabilidad a los principios religiosos de siglos anteriores no existía en los años finales del xv. De hecho, el motivo de la redacción de esta obra fue que: "Agora dubdaron algunas personas que ... si se pudo esto vedar, e si el prelado touo para ello autoridad, y especialmente si se pudo poner sentencia de excomunión en las personas que lo vno o lo al se atreuiessen a traspassar". Y recuerda que "a los pueblos y a los subditos e inferiores pertenece obedecer simplemente, e bien hazer y executar lo que los mayores supieron o supieren mandar y ordenars 6 . Un ejemplo práctico de esta nueva situación social viene testimoniado por la plena vigencia en estos años de las «leyes suntuarias". Estas leyes estaban destinadas a controlar el comportamiento y consumo privados en un periodo marcado por una alta movilidad y flexibilidad socioeconómica en el que los grupos sociales ascendentes tendian a mostrar en sus gestos exteriores su riqueza económica o su nueva posición social 7 . El propio Hernando de Talavera llega a afirmar: «porque

$4 \S 36$ de la presente edición.

5 Para una descripción de los diferentes elementos de la indumentaria en la época de los Reyes Católicos, y de los descritos por Hernando de Talavera, véase: C. Bernis, Trajes y modas en la España de los Reyes Católicos, Madrid 1978, espec. pp. 37-56.

$6 \$ 27$ de la presente edición.

7 Véase J. D. GONZALEZ ARCE, Apariencia y poder. La Legislación Suntuaria Castellana en los Siglos XIII-XV, Jaén, 1998. 
cada labrador e cada oficial, cada escudero, cada cibdadano y cada cauallero de pequeño y de grande estado excede manifiestamente no de lo natural solamente mas avn de lo que es permisso e tollerado a cada vno segun su estado" 8 . Esta dicotomía entre la realidad sociopolítica en la que desarrollaba su labor la Iglesia y los principios morales que ella defendía es la que explica la redacción de un tratado tan singular como el que aquí estudiamos.

La edición del manuscrito original, una vez corregido y cortado, no se puede explicar por casualidad. Su publicación y la simplificación del texto se enmarcan sin lugar a dudas dentro de la labor de adoctrinamiento de los musulmanes que Hernando de Talavera empezó a desarrollar en el reino de Granada tras la conquista castellana. En esos años la labor moralista de la Iglesia era un elemento activo de dominación política y social. La preocupación del arzobispo de Granada por las cuestiones alimentarias estaba totalmente vigente en las fechas en las que compiló esta obra. De hecho, entre 1492 y 1499 estuvo directamente dedicado a desarrollar su política de integración de los conversos, en la cual era imprescindible la eliminación de sus peculiaridades alimentarias. Así, en el Archivo Municipal de Granada encontramos una carta suya pregonada el 22 de marzo de 1498 en la que castigaba con pena de excomunión a cualquier cristiano que vendiera vino a los mudéjares o comprara carne degollada por ellos, o usara parteras musulmanas o alquilara sus casas a los mudéjares para hacer celebraciones de bodas. De fecha indeterminada, pero sin duda de poco después de la conversión general (alrededor de 1501), es una instrucción hecha por Talavera en respuesta a una petición de los vecinos del Albaicín sobre las prácticas cristianas que debian observar, en las que él aconseja abandonar sus costumbres religiosas incluidas los ayunos, las particularidades alimentarias y cualquier otra singularidad cultural ${ }^{9}$. La edición de este tratado en ese contexto histórico pretendía seguramente reforzar el papel de la Iglesia - y de Talavera-, dentro de la política de conversión de los mudéjares.

\section{NUESTRA EDICIÓN}

\section{a) Los manuscritos}

La edición que efectuamos de El Tratado sobre la demasía en vestir y calzar, comer y beber ha tenido en cuenta tanto la edición manuscrita como

$8 \S 94$ de la presente edición.

9 Archivo Municipal de Granada, Libro de Actas Capitulares, I, folios 60v-61r y Archivo General de Simancas, sección Diversos de Castilla, Legajo 8, pieza 114. Una edición electrónica del segundo texto se puede consultar en: http://www.geocities.com/CapitolHill/Lobby/2679/talavera.htm. 
la edición impresa de la misma. La obra original, escrita en 1477, se conserva en el manuscrito b.IV.26 de la Biblioteca del Monasterio de El Escorial. Ocupa los folios $31 \mathrm{r}$ a $95 \mathrm{r}$ de los 95 totales que lo componen, mientras que los restantes corresponden al tratado dedicado a María Pacheco, condesa de Benavente. Se trata de un manuscrito escrito en papel a dos tintas, los títulos y calderones en rojo y el resto en negro, con una caja de $201 \times 140 \mathrm{~mm}$.

La obra impresa, un compendio de la original, aparece incluida junto a otros trabajos del autor en el incunable número 2489 de la Biblioteca Nacional de Madrid, que se inicia con la Breve y muy provechosa doctrina cristiana de los que deben saber todo cristiano, su obra más conocida. El conjunto, editado en Granada alrededor de 1496 por Meinardo Ungut y Juan Pegnizer, lo componen 227 folios tamaño $4^{10}$ impresos a dos tintas y en buen estado de conservación. Está encuadernado con un pergamino flexible del siglo XVI. El tratado que estudiamos comprende únicamente 46 folios, los que van desde el fol. 158 al fol. 204.

\section{b) Diferencias entre ambos textos}

La mayoría de las oscilaciones que hemos observado en ambos textos tienen que ver con las transformaciones lingüísticas que se estaban produciendo en los años en que Talavera escribía, así como con el estilo general de ambas redacciones. De este modo se advierte el uso de una grafía más latinizante y un mayor arcaismo en el manuscrito. Además, este último presenta una organización expositiva más lógica, pero la estructura de capítulos y subcapítulos dificulta en ocasiones la comprension general, de ahí que seguramente el autor optara por una correlación en la numeración de los capítulos y eliminara los parágrafos dedicados a resumir de qué trata cada parte. En la versión impresa se eliminó la referencia a la fecha de composición del texto y los motivos que a ello le llevaron, y se suprimieron también largos párrafos en los que el autor se entretuvo en enumerar la superfluidad del uso de vestidos y adornos en las vestimenta masculina y femenina, quizá porque su edición en Granada pretendía concentrar el texto en algunos problemas concretos y darle nuevo vigor, tal como hemos señalado antes ${ }^{11 .}$

10 A título orientativo podría equipararse al de una cuartilla, pero técnicamente eso es poco riguroso. Véanse las especificaciones sobre los formatos en la obra de HaEBLER, K.: "Introducción al estudio de los incunables". Edición y notas de J. M. Abad, Madrid, Ollero y Ramos, 1995, pp. 73-78. Agradecemos a Isabel Moyano Andrés, del Servicio de Manuscritos, Incunables y Raros de la Biblioteca Nacional, la gentileza que tuvo al hacernos esta indicación.

1 Véanse $\$ 1,16 \mathrm{~b}, 35-39,104-108$ y nota 222. 


\section{c) Otras ediciones}

Hasta el momento, y a pesar del interés que este tratado de Talavera presenta, no se había emprendido la edición crítica del mismo. El uso de la edición impresa se remonta al estudio efectuado en el siglo XVII por Bartolomé Jiménez Patón en su obra Reforma de trajes. Doctrina de Fray Hernando de Talavera, editado en Baeza en 1638, de la que existe un ejemplar en la Biblioteca Nacional de Madrid (R. 137).

A principios del siglo $x x$, se procedió a la edición de los capítulos IV y $V$ del tratado, a cargo de Fr. Benigno Fernández, O.S.A., La Ciudad de Dios, LXXXVIII, pp. 167-174 y LXXXIX, pp. 110-118. Algunos de los descartes que no se incluyeron en el incunable fueron impresos por Sentenach en el Boletín de la Sociedad Española de Excursiones, XII (1903-1904). En 1911 Miguel Mir efectuó una edición íntegra del texto del incunable, junto a otras obras de Alejo Venegas, Francisco de Osuna y Alfonso de Madrid, en el primero de los volúmenes de la obra Escritores Místicos Españoles (páginas 57-78), editado en Madrid Bailly/Bailliere dentro de su colección Nueva Biblioteca de Autores Españoles. Recientemente, en el año 1998, se efectuó una edición facsimilar de la edición de Miguel Mir, con introducción de Antonio Garcia Benitez, a cargo de la editorial Padilla Libros con el título «De vestir y calzar: tractado provechoso, que demuestra como en el vestir e calzar comunmente se cometen muchos pecados...".

\section{d) Nuestra edición}

La presente edición crítica ha sido realizada a partir del cotejo del ejemplar manuscrito y del ejemplar impreso de la obra de Talavera. Se incluyen tanto los descartes que no fueron incluidos en el texto édito, como las modificaciones o diferencias lingüísticas y ortográficas existentes entre ambos textos. Nuestra edición permite un examen de la obra de Talavera más allá de su contenido explícito, ya que permite analizar una amplia gama de temáticas que, de otro modo, sería imposible de considerar.

Los cambios significativos en la redacción entre las dos versiones del tratado los hemos incluido en las notas a pie de página, mientras que los añadidos y la foliación de ambas versiones se incluyen en el cuerpo del texto. Para aclarar las diferencias textuales hemos utilizado los siguientes signos acrósticos:

- >texto< Trozos que no vienen en el texto original y que sí se incluyen en la edición impresa.

- /texto/ Las incorporaciones y añadidos del texto manuscrito original. 
- -x-Aparece la foliación del manuscrito.

- (fol.) Aparece la foliación de la edición impresa.

- [x] Numeración de cada párrafo, tal cual aparece en los textos originales, al que harán referencia los indices.

Para facilitar la lectura hemos puntuado el texto original y acentuado algunas palabras que, de otro modo, podrian dar lugar a equívoco.

\section{UTILIDADES PARA EL INVESTIGADOR}

\section{- Lingüística}

Las particularidades lingüísticas son muy numerosas y permiten un análisis detallado del lenguaje utilizado por Hernando de Talavera, y por extensión de aquél usado por los eruditos de la Iglesia al inicio de la Edad moderna. Una investigación de este tipo podría servir para analizar el proceso de vulgarización de la lengua castellana dentro de un grupo altamente latinizado como era el de los intelectuales eclesiásticos. El análisis de los dos textos del tratado evidencia la influencia del latín en la redacción castellana de Talavera: oscilaciones en el uso de la conjunción copulativa y/e, terminaciones en tia en lugar de cia; el uso de dobles consonantes, especialmente $c c$ en lugar de $c$, alternancia $v$ y $u$ con valor consonántico o vocálico; confusión entre le $Y$ y entre fy ph; uso de io $j$ ( $i$ larga); oscilación entre uso de no o non cuando se niega al verbo; duda entre el uso de $s c$ y $\zeta$, etc. Al mismo tiempo se observan alternancias fonéticas y gramaticales que estaban afectando a la lengua castellana durante aquellos años: confusión $c$ y $c ̧$, duda al usar les y los, alternancia entre el uso de $n$ o $m$ antes de $p$, confusión entre $z g$ y $d g$, aparición y desaparición de la $h$, alternancia entre $f$ y $h$; oscilación entre el uso de ere y erre en mitad de palabra, y mucho más.

\section{- La cultura Clasica y los Hombres de Iglesia}

Un análisis de las fuentes que Hernando de Talavera utiliza para apoyar su discurso permite observar los elementos que la erudición eclesiástica de la Baja Edad Media consideraba indispensables en un discurso moral. Además, permite averiguar qué libros y teorías clásicas estaban circulando entre los intelectuales de la época. Talavera cita entre los profetas a Elías, Isaías, Baruch, Isaac, Ezequiel, Daniel, Eliseo, David, Moisés y Sofonias; entre los Padres de la Iglesia menciona a Basilio, Ambrosio, Juan Crisóstomo y Cipriano, mientras que los Apóstoles de referencia son Pedro y Pablo. 
También usa ejemplos procedentes de la vida de algunos santos tales como Gabriel, Cecilia, Martín, Sebastián, Marina, Jerónimo y Tomás; episodios bíblicos procedentes del Génesis, los Salmos, Libro de los Reyes, los Evangelios de Juan y Lucas, el Apocalipsis, los Hechos de los Apóstoles, aparte de referencias a otros episodios del Viejo Testamento. Cita también a Tomás de Aquino e Isidoro de Sevilla, y hace referencias explícitas a Platón y a la Filosofía Natural. El recurso a la Patrística y a los filósofos clásicos es de primera mano. Sabemos por el testamento de Hernando de Talavera, que su biblioteca la componían 182 volúmenes que incluian obras de la Sagrada Escritura, de los Santos Padres Latinos, de los grandes teólogos medievales (especialmente Agustín y Tomás de Aquino), de los autores clásicos latinos (Aristóteles, Platón y Cicerón sobre todo), las obras fundamentales del Derecho Civil y Canónico y las de los famosos autores árabes como Avicena y Averroes en su versión o traducción latinas ${ }^{12}$.

\section{- Historia del Traje y/o del Vestido}

Algunos de los apartados del tratado sirven a modo de inventario de los elementos de la vestimenta y el calzado de los años finales del siglo XV, permitiendo por añadidura establecer el simbolismo del uso de ciertos colores y su relación con la jerarquía social. Por lo demás, el tratado de Talavera puede ponerse en relación directa con las llamadas leyes suntuarias o leyes contra el lujo que se extienden a lo ancho de Europa a partir del siglo xill, aunque sin mucho éxito en su aplicación. En el caso de Castilla la primera carta que controlaba el uso de la seda y los adornos personales fue emitida el 30 de septiembre de 1499, y ofrecía tanto normas aplicables al conjunto de la población como concesiones a los caballeros armados, a las personas de las familias que mantenian caballo, así como a los maestros y patrones de naos. En enero de 1500 se publicó en Sevilla otro documento aclarando y corrigiendo la precedente, por el cual se hacía excepción con las mujeres asturianas y vizcaínas en atención a lo antiguo de sus trajes, autorizándose además ciertos adornos al conjunto de la población. En 1506, sin embargo, los procuradores presentes en las Cortes de Valladolid hicieron una petición al rey —nunca atendida - solicitando una reforma de las pragmáticas anteriores con el fin de establecer diferencias mayores entre los distintos grupos sociales, ampliando las concesiones a los más poderosos y reduciendo o anulando los derechos de los más humildes ${ }^{13}$. El

12 Q. ALDEA, «Hernando de Talavera, su testamento y su biblioteca», en Homenaje a Fray Justo PErez de Urbel OSB, (Studia Silensia III), 1976, I, pp. 513-547.

13 Véanse: C. BERNIs, Trajes y Modas en la España de los Reyes Católicos, Madrid, 1978, pp. 5763; J. D. GonzÁLEZ ARCE, Apariencia y Poder. La Legislación Suntuaria Castellana en los Siglos XIII-XV, 
estudio de la procedencia de los tejidos y materiales mencionados puede servir además para observar las redes comerciales que existían en torno al mundo de la vestimenta y el calzado en aquella época.

\section{- Alimentación}

El interés por la cuestión de la vestimenta, que es el prioritario a la hora de escribir esta obra, dio paso al de la comida, tal como reconoce el mismo Talavera: «No era tanto de nuestro propósito dezir de los excessos del comer y del beuer mas como parece de lo susodicho, de lo vno e de lo otro, es quasi vna sentencia e vn mesmo juyzios 14 . Aunque la obra no es un tratado dedicado a los sentidos ni tampoco al gusto o a la comida, lo cierto es que la información que proporciona sobre el comer y el beber permite afrontar el tema de la concepción del gusto dentro de la ideología imperante en la moral bajomedieval 15 . Al igual que todo lo creado por Dios, los alimentos son intrínsicamente buenos pero las circunstancias que rodan su consumo son las que se asocian con el pecado. Este hecho permite estudiar el papel de los alimentos y los comportamientos alimentarios dentro de la doctrina cristiana, la relación de la alimentación con el pecado, el simbolismo religioso de determinados alimentos o grupos alimentarios, la relación entre Paraíso y alimentos, la conexión entre jerarquía social y consumo alimentario, las teorías dietéticas imperantes y su relación con la justificación del orden social establecido, por poner sólo algunos ejemplos.

\section{- Otros temas}

La visión de la jerarquía social; la concepción que los eclesiásticos tenían sobre el papel de la Iglesia en la sociedad bajomedieval; la relación entre jerarquía social, vestimenta, alimentación y sexo, o los elementos que componían la normativa dietética cristiana medieval son sólo algunos ejemplos de las muchas posibilidades que una obra como la que editamos presenta para medievalistas y modernistas.

\footnotetext{
Jaén, 1998, pp. 74-177. Datos generales sobre las prohibiciones en otros países europeos se encuentran en C. Kippen, The History of Footwear. Sumptuary Laws, Curtin University of Technology, Perth, disponible en: http://www.curtin.edu.au/curtin/dept/physio/podiatry/sump.html. En la actualidad Mercedes Csés URRICELoUl está realizando una tesis doctoral titulada Poder, Simbologia y Representación en la Baja Edad Media: el Ajuar en la Corte de Carlos III de Navarra (1387-1420) en la que incluye el estudio de la vestimenta y el calzado.

${ }^{14} \S 122$ de la presente edición.

15 Usamos el presente tratado para redactar la ponencia titulada «El gusto en la doctrina Moral de la Iglesia según Hernando de Talavera", presentada en el Colloque Internationale Micrologus: Les Cinq Sens au Moyen Age, organizado en Lausana (Suiza) entre los dias 27-31 de octubre de 1999.
} 


\section{"DE LA DEMASÍA EN EL VESTIR Y CALÇAR...»}

[1] Tractado prouechoso que demuestra como en el vestir e calçar comunmente se cometen muchos pecados, $y$ aun tanbien en el comer y >en el< beuer, hecho y conpilado por el liçenciado Fray Hernando de Talauera, indigno prior >entonces< del monesterio de Sancta Maria de Prado, que es extramuros de la $>$ noble< villa de Valladolid, $>$ y despues primero arçobispo de la Santa Yglesia de Granada, y confessor de la muy catholica reyna de España Doña Ysabel, primera deste nonbre<, /en el año del nascimiento de nuestro saluador Ihesuchristo de mill e quatroçientos y setenta y siete años, incitado y despertado a ello por la disçiplina y açote de la grand sterilidad con que Nuestro Señor castigó sus pueblos este dicho año, especialmente a toda la Tierra de Campos/.

[2] /Tiene çinco partes. La primera que es como prólogo e introduction tiene tres capitulos/. Capitulo primero, demuestra ${ }^{16}$ que los pueblos e qualesquier subditos e inferiores deuen simplemente -31 v- obede $>\mathbf{S}<$ cer a sus gouernadores e mayores sin demandar causas ni>n< razones de los mandamientos que les son hechos ${ }^{17}$.

[3] El segundo capitulo, demuestra la causa e oportunidad de escriuir este tractado.

[4] El tercero capitulo toca breuemente algunos motiuos e razones que allegan algunas personas diziendo que no se deue poner ley cerca de los trajes ${ }^{18}$. (fol. 158v)

[5] /II. La parte segunda demuestra que en el uestir y calçar hay algo natural y como necessario y algo o mucho voluntario, y assi mesmo en el comer y en el beuer. Tiene ocho capitulos/.

Capitulo IIII 19. /Demuestra/ como es cosa natural que trayamos las carnes cubiertas.

[6] Capitulo $V^{20}$. /Demuestra/ que tanbien es cosa natural que de vna ma-32-nera se vista el varon y de otra >manera < la hembra, y que generalmente cada vno sea vestido como es menester para mejor ${ }^{21}$ executar su officio.

\footnotetext{
$16 \mathrm{Ms}, 31 \mathrm{r}:$ El primero es demostrar.

$17 \mathrm{Ms}, 31 \mathrm{v}$ : mandamientos que les ponen.

$18 \mathrm{Ms}, 32 \mathrm{r}$ : personas, especialmente dueñas que algunos trajes no se pudiessen uedar.

19 Ms, 31v: primero.

$20 \mathrm{Ms}, 31 \mathrm{v}$ : segundo.

$21 \mathrm{Ms}, 32 \mathrm{r}$ : para bien.
} 
[7] Capitulo VI 22. /Demuestra/ que es tanbien ${ }^{23}$ cosa natural que el varon traya la cabeça descubierta, saluo por neces $>$ s $<i d a d, y>$ que $<$ la muger >la traya < cubierta. -32v-

[8] Capitulo VII ${ }^{24}$. /Demuestra/ que ${ }^{25}$ naturalmente se mudan las vestiduras y el calçado segun/d/ que se mudan los /quatro/ tiempos del anno.

[9] Capitulo VIII 26. Como en el vestir >e calçar< es algo o mucho voluntario, e como en esto, que es voluntario, acaece muchas vezes errar y pecar ${ }^{27}$.

[10] Capitulo IX ${ }^{28}$. Que el comer y vestir andan y deuen andar por vna manera $o>$ por vna $<$ regla.

[11] Capitulo $X{ }^{29}$. Que tanbien /h/ay en el comer y beuer voluntario e natural como en el vestir $y>$ en el< calçar. (fol. 159r)

[12] Capitulo $X I^{30}$. $>$ De $<$ como Nuestro Señor Dios nos enseñó que en el comer y beuer / $h$ /ay y deue auer muchas di/f/ferencias e diuersidades naturales /apuntadas en el capitulo precedente/.

[13] /Tercera parte. Tercera parte demuestra más en espeçial çinco maneras en que en tomar el mantenimiento acaeçe comunmente peccar, y assimesmo en el uestir y calçar; tiene siete capitulos/.

Capitulo XII ${ }^{31}$. De la primera manera en que acaece ${ }^{32} \mathrm{pe} / \mathrm{c} / \mathrm{car}$ en /el/ vestir $y>$ >n< calçar assi como en tomar el mantenimiento, >que es< quando se haze en demasiada quantidad.

[14] Capitulo XIII 33. /Demuestra/ que el tal excesso >de vestir y de calçar< es pe/c/cado de soberuia, /y/ contrario -33r- a la humildad, que es vna de tres virtudes que en el vestir e calçar tienen el medio e guardan la honestad, $y$ avn demuestra/n/ que $>e<1$ tal excesso tanbien es pe/c/cado de auaricia $y>$ de $<$ rapiña.

[15] Capitulo XIIII ${ }^{34}$. De la segunda manera en que en el vestir y calçar, assi como en comer y beuer, acaece pe/c/car.

\footnotetext{
22 Ms, 32r: tercero.

23 Ms, 32r: que tanbien es.

24 Ms, 32r: quarto.

25 Ms, 32r: como.

$26 \mathrm{Ms}, 32 \mathrm{r}$ : quinto.

$27 \mathrm{Ms}, 32 \mathrm{r}$ : peccar y errar.

$28 \mathrm{Ms}, 32 \mathrm{r}$ : sexto.

29 Ms, 32v: septimo.

$30 \mathrm{Ms}, 32 \mathrm{v}$ : octauo.

$31 \mathrm{Ms}, 32 \mathrm{v}$ : primero.

$32 \mathrm{Ms}, 32 \mathrm{v}$ : aconteçe.

$33 \mathrm{Ms}, 32 \mathrm{v}$ : segundo.

$34 \mathrm{Ms}, 33 \mathrm{r}$ : tercero.
} 
[16a] Capitulo XV ${ }^{35}$. De la tercera manera de pe/c/car, que es buscando mill maneras e nouedades de vestiduras y de trajes, como en el comer /y beuer/ muchos guisados adobados e potajes; (fol. 159v) /y especialmente pone algunas practicas de como en nuestros tiempos han excedido y exceden en aquesta manera los varones/.

[16b] /Capitulo V. Pone praticas como en la manera susodicha han exçedido y exçeden las mugeres/ ${ }^{36}$. -33v-

[17] Capitulo $X V \mid{ }^{37}$. De>muestra < la quarta manera de exceder $y$ peccar en comer y en beuer, y en vestir y en calçar, que es no guardando la conueniencia del tiempo.

[18] Capitulo XVII ${ }^{38}$. De la quinta manera de pec/c/ar en lo suso dicho, que es comiendo o vistiendo con grand $>e<$ ardor y deleyte, $e^{39}$ haziendo nueuas inuenciones y trajes.

[19] /Quarta parte. Demuestra que el hábito susodicho deshonesto y peregrino de las caderas y uerdugos se deuió y pudo muy bien uedar en la manera que fue uedado. Tiene ocho capitulos/.

Capitulo XVIII ${ }^{40}$. /Demuestra/ que los prelados e regidores de las comunidades pueden y deuen ordenar e poner ley e leyes cerca de los trajes. $-34 r-$

[20] Capitulo XIX ${ }^{41}$. /Demuestra/ que Dios, Nuestro Señor, quando regía al pueblo de Ysrael por sí mesmo, antes que le diesse rey y despues, esse mesmo Dios humanado en la persona del hijo, e los Santos Apostoles, $y>$ despues < los Santos Doctores antiguos e modernos, pusieron ley e leyes $/ a /$ cerca de los trajes ${ }^{42}$.

[21] Capitulo $X X{ }^{43}$. Que los prelados eclesiasticos pudieron e avn deuieron vedar, so pena de exco/m/munion, que aquel hábito deshonesto no $>n<$ se vsasse más.

[22] Capitulo XXI ${ }^{44}$, y mucho de notar, demues(fol. 160r)tra quando el /excesso $y /$ superfluo $>y$ demasiado $<$ comer $y$ tra $>h<e r$ es $\mathrm{pec} / \mathrm{c} / \mathrm{ado}$ mortal.

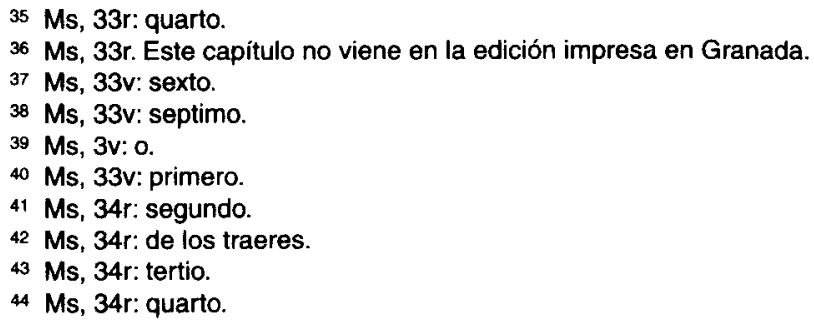


[23] Capitulo XXII 45. Demuestra por doze razones que aquel traje descomulgado de caderas $y>d e<$ verdugos es muy malo e, por consiguiente, muy deuidamente -34v- reprobado y vedado; y aqui toca de los afeytes quando son $\mathrm{pec} / \mathrm{c} / \mathrm{ado}$ venial y quando $\mathrm{pec} / \mathrm{c} / \mathrm{ado}$ mortal.

[24] Capitulo XXIII 46. /Demuestra/ que los motiuos e razones de dubdar cerca de lo susodicho, que al comienço fueron apuntados, no son sufficientes para impedir nin estoruar que lo sobredicho no sea muy bien ordenado y que deua ser muy bien guardado.

[25] Capitulo XXIIII 47. /Demuestra/ que en la /muy/ noble villa de Valladolid, más que en otro ningun/d/ lugar, se deuió aquello reprobar y vedar. $Y$ pone fyn al tractado ${ }^{48}$. (fol. 160v)

\section{[26] -35r-/Comiença el Tractado/}

Capitulo primero/desta primera parte/. Demuestra que los pueblos e qualesquier subditos e inferiores deuen simplemente obede $>s<c e r$ a sus gouernadores e mayores sin demandar causas ni razones de los mandamientos $>$ que les son hechos<.

[27] Son algunas personas que, contra la do/c/trina del Santo Apostol, quieren saber más de lo que deuen, $y$ en su saber no se quieren tenplar. $Y$ estas son todas aquellas que no quieren obede $>s<c e r$ e complir el mandamiento y mandamientos de sus regidores y prelados en lo que no es conoscidamente malo, sin que les den razon e cuenta por qué se mouieron a mandarlo, $y$, avn lo que es peor, sin que examinen primero si tienen o touieron poder para mandar aquello. No miran/do/ que a los pueblos $>y$ a los subditos $<$ e inferiores -35v- pertenece obedecer simplemente ${ }^{49}$, e /solamente/ bien hazer y executar lo que los mayores supieron o supieren mandar y ordenar. El que a vos oyere - dixo Ihesuchristo hablando con los prelados- a mí oye, y el que menosprecia a vos a mí menosprecia. (fol. 161r)

[28] Como ouejas y como corderos quiso Ihesuchristo que fuessemos y que obede>s<cies/s/emos a nuestros pastores, assy simplemente como los obede>s<cen aquéllas y aquéllos; simples quiso que fuessemos como palomas, que no tienen aquellas astucias $y^{50}$ resaberes que las aues caça-

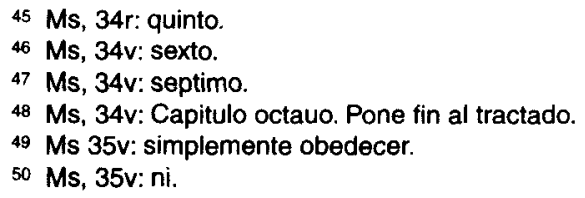


doras. Uerdad es que quiso que fuessemos prudentes como serpientes, que cierran las orejas por no oyr a los encantadores ${ }^{51}$ y que guardan principalmente las cabeças que no sean heridas en ellas, segund que 52 auemos nos de guardar que nuestros prelados, que son nuestras cabeças, no re>s<ciban daños ni menguas. $-36 \mathrm{r}$. $E$ auemos de guardar que sean sanas nuestras intenciones y que sean buenos nuestros pensamientos, que son cabeças e comienços de nuestras obras ${ }^{53}$; y que como las culebras se meten por estrechos agujeros para dexar los cueros viejos, que as/s/i nos entremos por el camino estrecho >y aspero< de la penitencia para despojar y desechar, como dize el Apostol, el onbre y ${ }^{54}$ cuero viejo de nuestros pe/c/cados y yerros.

[29] Pues en estas tres cosas quiso Nuestro Señor que fuessemos prudentes como las serpientes, mas no en demandar razon de los mandamientos, (fol. 161v) como hizo la maldi/c/ta culebra quando engañó a nuestra madre Eua. Ca ésta fue rayz de toda su cayda y pecado 55: querer saber por qué le fuera aquello mandado, y avn poner dubda si se pudo mandar buenamente o si se pudo poner aquella pena de muerte, ca respondio porque por ventura -36v- no muramos, puso dubda en lo que se mandó sin dubda.

[30] Esse mesmo Ihesuchristo reheprende a los maliciosos preguntadores ${ }^{56}$ que le demandauan qué poder tenia para echar del tenplo a los cambiadores y negociadores. E no solamente quiere e manda que oyamos y obedezcamos a los prelados que son buenos, mas avn a los escriuanos $e$ phariseos, esto es a los malos y peruersos, tanto que hagamos lo que nos dizen mas no los males que hazen ellos en grand conde $>n p<$ nacion de sus ánimas, que serán más que ningunas muy terriblemente ${ }^{57}$ atormentadas en los infiernos.

[31] Concuerda el apostol Sant Pedro que manda obedecer no solamente a los prelados buenos e modestos ${ }^{58}$, mas avn a los malos y des $/ \mathrm{h} /$ onestos en tanto que son tolerados e auidos por prelados, a gran $/ \mathrm{d} /$ cargo y pe/c/cado del que $>$ los $<$ ha de $>$ corregir $y<$ emen(fol. 162r)dar/los/.

[32] Uerdad es -37r- que esse mesmo Dios y señor nuestro, quando dio la ley a Moysen, dio razon de algunos mandamientos: como de la guarda

$51 \mathrm{Ms}, 35 \mathrm{v}$ : maldizientes.

$52 \mathrm{Ms}, 35 \mathrm{v}$ : como.

$53 \mathrm{Ms}, 36 \mathrm{r}: \mathrm{Y}$ que nuestras intentiones y pensamientos, que son cabeças y comienços de nuestras obras, guardemos que sean sanos y buenos.

54 Ms, 36r: el.

$55 \mathrm{Ms}, 36 \mathrm{r}$ : rayz de todo su peccado.

$56 \mathrm{Ms}, 6 \mathrm{v}$ : preguntadores maliciosos.

57 Ms, 36v: crueimente.

$50 \mathrm{Ms}, 36 \mathrm{v}$ : honestos. 
del sa/b/bado entre los morales, y de no comer carne con sangre en los cerimoniales, y de no recebir dones los juezes entre los judiciales, e assi de otros algunos. Pero esto fue muy raras vezes e por causas especiales assi como en lo del sab/b/ado, porque aquel mandamiento en parte era /en parte/ moral y en parte cerimonial e judicial; $y$ en lo de la carne con sangre por que ab/b/orresciessen el pe/c/cado del homicidio $y>$ de $<$ todo derramamiento de sangre humanal; e dio causa de no recebir dones ${ }^{59}$, por que no se engañe ninguno por sabio e bueno que sea pensando que no le podran peruertir y cegar. $Y$ generalmente dio algunas >vezes< razones, por que aquel pueblo duro de ceruiz e tardinero en creer viesse por algunas -37v-cosas e creyesse que Dios, Nuestro Señor, razonablemente e non sin causa, mandaua todas las otras.

[33] $Y$ avn assi dezia Nuestro Redenptor a sus discipulos algunas cosas de las que luego auian de ser ante/s/ que fuessen, porque, veyendo complir aquéllas, esperassen que las otras $>$ todas $<$ que dezia o di(fol. 162v) $\mathrm{x} / \mathrm{i} / \mathrm{esse}$ serian ciertas. $\mathrm{Ca}>\mathrm{en}<$ las cosas futuras que no $>n<$ tienen causas necessarias, mas que pueden ser y no ser segun/d/ las causas propinquas, no /h/ay más ni menos razon de acertar en vnas que en otras, como en los miraglos ${ }^{60}$ que requieren infinito poder: no es más hazer muchos que vno ni>n menos hazer < vno que muchos, porque el poder infinito a infinitas cosas se extiende, y vn infinito si muchos puediessen ser no seria mayor que otro, nin avn muchos podrian más que vno, y por esso no ay más de vno.

[34] Pero esto es mucho -38r- de notar que aquellos mandamientos de aquel tiempo se hallan menos guardados, en que se dio $/ \mathrm{la}$ razon del mandamiento. El mandamiento del sab/b/ado helo del todo mudado. Por esto entienden que el rey Salomon ouo o/c/casion de tomar muchas mugeres, porque $>e<1$ mandamiento que lo vedaua dio luego razon dello, ca dixo: porque no turben el coraçon del rey e lo inclinen a mal hazer; lo qual, >ék < confiando en la gran/d/sabiduria que Dios le dio, pensó que nunca le pudiera acaescer. Assi que no deurian los sub(tol. 163r)ditos demandar razon de lo que les es mandado ni menos deurian mucho espulgar si tienen bastante poder los gouernadores que les mandan lo bueno que deuen e pueden bien hazer. Mas por conuencer malicias e quitar o/c/casion -38v- de escandalo pueden y deuen los prelados a las vezes satisf/f/azer a su curiosidad e dar razon de lo mandado y de su au/c/toridad, avnque sean como lo son libres deste cuydado e non tengan necessidad. Ca assi pagó Jesuchristo ${ }^{61}$ el tributo por no escandalizar, avnque él y sus discipulos tenian conplida libertad.

\footnotetext{
59 Ms, 37r: $Y$ en lo de los dones.

60 Ms 37v: miembros.

6. Ms, 38v: Ihesuchristo.
} 
[35] Capitulo II‥ Demu/e/stra la causa e oportunidad de escreuir este tra/c/tado.

[36] Es dicho lo susodicho porque en la muy noble villa de Valladolid fue ordenado por el prelado eclesiastico ${ }^{62}$ que, so pena de exco/m/munion $/ y$ de otras penas pecuniarias y de destierro/, no $>n<$ trax//essen los varones ni las mugeres cierto traje deshonesto: los varones camisones con cabeçones labrados ni las mu-39r-geres, grandes ni pequeñas, casadas ni donzellas, hizie/s/sen verdugos de nue (fol. 163v) uo ni traxiessen aquella demasia que agora vsan de caderas, y a los sastres que no lo hiziessen de $>$ nde $<$ /alli/ > en < adelante so essa/s/ mesma/s/ pena/s/. Agora dubdaron algunas personas que en el junco buscan nudo y lo claro hazen obscuro: si se pudo esto vedar, e si el prelado touo ${ }^{63}$ para ello au/c/toridad, y especialmente si se pudo poner sentencia de excomunion en las personas que lo vno $0^{64} \mathrm{lo}$ al se atreuiessen $>\mathrm{a}<$ traspassar.

[37] $Y$ las personas que menos creen que esto se pueda vedar $65 y$ $>$ que $<$ más quieren tra/n/scender son algunas mugeres ${ }^{66}$, y esles de sup/p/ortar porque es su natural desde la primera muger que traspassó el mandamiento por cobdicia de saber. Sereys - le dixo la serpiente- assi como -39v-dioses sabientes bien e mal, e no fue más menester, prestas para creer el mal y tardineras para el bien. Plega a Nuestro Señor, a cuya gloria se escriue todo, que $\mathrm{a} / \mathrm{s} / \mathrm{si}$ como aquella ligereza fue causa de muy grand bien, ca fue causa del misterio de la > preciosa < Incarnacion y de la muerte e passion de Nuestro Redenptor, assi sea esta tardança de creer causa de mucho bien, porque sepan las >personas, onbres (fol. 164r) $\mathrm{y}<$ mugeres, cómo se han de traher.

[38] Gane gracia para ello la Reyna de los Ángeles 67 que nunca supo pe/c/car, y >que< tardaua de creer y ouo de preguntar cómo podia ser lo que >le< dezia el santo $A>r c h a n<$ gel Gabriel, e no dio consentimiento hasta que le dixo la manera y le puso algun/d/ exenplo. O bienauenturada henbra que assi mira e assi se atienta en su creer y responder. $O$ muy prudente e muy sabia Virgen, porque no digamos muger que quiere dezir -40rmuelle o mouible, que escarmentada en la primera virgez ${ }^{68} e>$ avn mas< in/n/ocente que ${ }^{69}$ ella examina bien primero $>$ ante ${ }^{70}<$ que aya de creer si

$62 \mathrm{Ms}, 38 \mathrm{v}$ : por los venerables prouisores y por otros uenerables padres y honorables señores para ello deputados.

63 Ms, 39r: y aquellos señores que lo vedaron touieron.

64 Ms, 39r: y.

65 Ms, 39r: que esto puede ser.

66 Ms, 39r: mas son hembras que varones.

$67 \mathrm{Ms}, 39 \mathrm{v}$ : de los cielos.

$68 \mathrm{Ms}, 40 \mathrm{r}$ : uirgen.

69 Ms, 40r: como.

70 Repetido: ante. 
puede y deue aquello ser. O humildad muy profunda, que se oye nombrar llena de gracia, $y>e s<$ que es escogida para madre del fijo de Dios, saluador del mundo y rey soberano, cuyo reyno no avrá fin, mas non se apressura luego a dezir ${ }^{71}$ : heme aqui, sea hecho assi.

[39] Digo que es natural a las mugeres la cobdicia del saber $>$ porque aquella cosa es naturalmente más cobdiciada< de que tenemos mayor falta, pues, como tengan comunmente el entendimiento y la discretiua más flaca que los varones, parece que no sin causa ${ }^{72}$ quieren suplir su defecto, el qual $>$ se< su(fol. 164v)ple $>n<$ sabiendo. Iten, les es cosa más natural creer el mal de ligero porque, >como < todos somos prouos al mal, /y tanbien/ por la flaqueza del entender, son ligeras de ${ }^{73}$ engañar /los que no saben discerner/ >y de creer el mal antes que el bien<. $-40 \mathrm{v}$ - $E$ avn de aqui les viene que para creer lo bueno sean tardas, porque temen ser engañadas, pues esles de supportar.

[40] Capitulo 3\%. Toca breuemente algunos motiuos e razones que al/Vegan algunas personas, especialmente dueñas, que los trajes no se pueden assy vedar.

[41] Muéuelas a creer que los trajes no se pueden vedar, porque piensan que cada vno e cada vna se puede vestir a su voluntad, y piensan que en el vestir no / $/$ /ay regla cierta, porque veen que /h/ay, e siempre vuo (sic), en cada tierra su vso, y que aquello generalmente es ap/p/robado, que es tenido e vsado.

[42] $Y$ de aqui viene lo segundo, que como piensan que en el vestir $e$ traher no /h/ay pe/c/cado señaladamente mortal, a/s/si piensan que ninguno puede por ello descomulgar 74 porque la $>d<e x c o m u n i o n$, especialmente la -41r- ma(fol. 165r)yor, es cierto que no es pena syno de pe/c/cado mortal 75 . Oyen dezir que el Derecho Canonico que quiso que los clerigos traxiessen hábito honesto nunca les determinó la forma y manera del, avnque algo les vedó.

[43] Éstas y semejantes razones las mueue $>n<$ a dubdar y tardar en creer que aquello se pudiesse assi vedar y porque /piensan que/ no se vieda en todo el reyno /en el qual se usa aquesto/.

\footnotetext{
71 Ms, 40r: no se atreve a dezir.

$72 \mathrm{Ms}, 40 \mathrm{r}$ : merito.

73 Ms, 40r: ca ligeros son.

$74 \mathrm{Ms}, 40 \mathrm{v}$ : por ello ninguno puedo descomulgar.

$75 \mathrm{Ms}, 41 \mathrm{r}$ : que es pena de solo pecar mortal.
} 


\section{[44] /Segunda parte deste tractado/.}

\section{Capitulo quarto, /primero en esta segunda parte/. Demuestra como es cosa natural que trayamos las carnes cubiertas.}

[45] Para demostrar y conoscer quán justa y >quán< razonablemente lo sobredicho fue ordenado es primeramente de saber que en el hábito y compostura, tanbien de los varones como de las mugeres, es algo y avn mucho natural $>y<$ que no se puede ni deue mudar, porque las cosas naturales son inuariables $\mathrm{y}>\mathrm{es}<$ algo -41v-ad placitum y voluntario.

[46] Natural cosa es que cubramos nuestras carnes, a/s/si por que sean guardadas del frio y de la calura, y de las otras cosas que las podri(fol. 165v)an enpecer si andouiessen desnudas, como porque seria cosa vergonçosa no las tra $>h<e r$ cubiertas.

[47] De lo primero dize el sabio que lo su/b/stancial y necessario para conseruacion de la vida humana es pan y agua, vestidura y casa. De lo segundo dize la Sagrada Scriptura 76 que luego que nuestros padres primeros $77 \mathrm{pe} / \mathrm{c} / \mathrm{caron}$ ouieron verguença de se ver desnudos. $\mathrm{E}$ a/s/si dize el Apostol que los miembros que son en nos más des/h/onestos aquéllos honestamos más, conuiene saber: cubriendolos más que $>a<$ los otros que de sí son honestos, y por esso ${ }^{78}$ aquellos primeros padres principalmente cubrieron luego las partes vergonçosas. Ca cosieron como mejor pudieron con juncos o con miembres 79 , /o vnas -42r- con otras/ sendas cintas de hojas de higuera y cubrieron con ellas sus verguenças, a/s/si que la primera vestidura que ouo en el mundo >despues del pecado < fueron los paños menores $o$ algo en lugar dellos.

[48] Digo que despues del pe/c/cado aquellos primeros padres ouieron verguença de se ve/e/r a/s/si desnudos, porque antes que pe/c/cassen non auia des/h/onestidad de que ouiessen verguença (tol. 166r) porque los vestia e honestaua lan (sic) in/n/ocencia. Como no han verguença 80 los niños que avn no saben $\mathrm{pe} / \mathrm{c} / \mathrm{car}$, ni la ouo Jesuchristo ${ }^{81}$ de ser puesto por nos ${ }^{82}$ en la cruz qual su Santa Madre lo ${ }^{83}$ parió, porque nunca pe/c/có, ni avn pe/c/cado original, mas sienpre tuuo la innocencia en que fue criado Adan. Y assi le llama el Apostol, nuestro Adam segundo, formado de sangre

\footnotetext{
$76 \mathrm{Ms}, 41 \mathrm{v}$ : dize el texto.

$77 \mathrm{Ms}, 41 \mathrm{v}$ : primeros padres.

78 Ms, 41v: esto.

79 Ms, 42r: mimbres.

80 Ms, 42r: Como no la han.

$81 \mathrm{Ms}, 42 \mathrm{r}$ : Ihesuchristo.

$82 \mathrm{Ms}, 42 \mathrm{r}$ : por nos puesto.

83 Ms, 42r: le.
} 
virgen purificada y amassada por la virtud del Spiritu Sancto en aquel vientre virginal como el primero -42v- Adan fue formado de tierra virgen bermeja, limosa y cenosa en el campo damasceno.

[49] Por pura verguença de se ver as/s/y desnudo dize el primero pa-

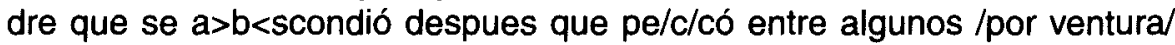
jazmines o en algun/d/ espesso cidral, que no osó as/s/i parecer ante la Magestad Diuinal. Y avn as/s/i dize Sant Juan en su ${ }^{84}$ Apocalipsi avnque habla de las > vestiduras< spirituales que son las virtudes, que es bienauenturado el que guarda sus vestiduras >por<que no parezca desnudo en el Dia del Juyzio; en el qual es cierto que todos los predestinados y justos resu/s/citarán con cuerpos vestidos de claridad gloriosa, mas los prescitos y pecado(fol. 166v)res que al infierno son conde>m<nados desnudos se leuantarán, feos y malauenturados.

[50] Assi que es cosa natural que trayamos vestiduras y andemos cubiertos, o por necessidad de anparar y conservar los cuerpos -43r- o por que no parezcamos desonestos ${ }^{85}$.

[51] Y porque en el Paraiso Terrenal no son las vestid/ur/as necessarias >para conseruar el cuerpo< por la salubridad y tenperança ${ }^{86}$ de aquel sancto lugar, por esso el santo profeta Helias dexó alguna de sus vestidu$\operatorname{ras}^{87}$ quando fue arrebatado en carro de fuego y lleuado allá a morar.

[52] De lo dicho ${ }^{88}$ se siguen tres cosas prouechosas y de notar. La primera, que la demasia de las vestiduras es culpable y se deue euitar como cosa $>$ no $<$ necessaria $y>$ por consiguiente $<$ no $>n<$ natural; $y$ por esso Nuestro Redenptor mandaua que nos contentassemos con vna saya si aquella pudiesse $>a<b a s t a r$. La segunda, que es grand vanidad preciarse alguno de andar mucho arropado, pues que es a/s/si /la/ verdad que las vestiduras introduxo el pe/c/cado, por mucho liuiano auriamos y mucho indis(tol. 167r)creto al que se preciasse y honr/r/asse de tra $>$ h<er muy $-43 v$ - luengo >el< cabello, el qual 89 le es necessario para >en<cobrir la falta de las orejas que le cortaron porque hurtó ${ }^{90}$. La tercera, que es des/h/onesto y mengua de buena verguença traher descobiertas algunas partes del cuerpo, >las quales podrian andar cobiertas, asi como a varones y avn a las mugeres es vergonçoso los traher discobiertos los pechos porque non ay necessidad que deuan andar descobiertos; uerdad es que

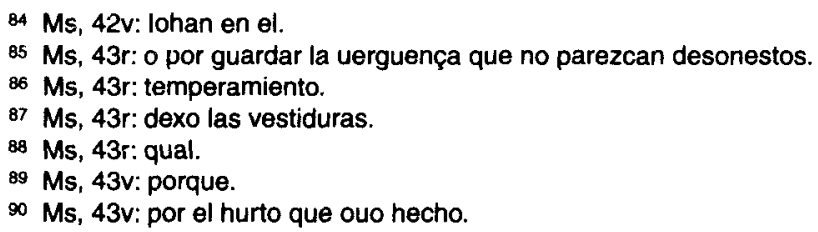


las mugeres que crian deuen traher las tetas ligeras de sacar $<91$. Seno dize muchas vezes la Sancta Scriptura del varon y de la muger, lo qual no ha lugar ni puede ser perfe/c/to, si el pecho anda discobierto: aljubas trayan en buen tiempo que cubrian todo el pecho; gorguera trayan siempre 92 delgada o basta, que cobria ${ }^{93}$ las espaldas y pechos enteramente hasta la -44r- garganta; $y$ avn vsauan sartales, anchos collares y almanacas, porque la honestad demanda que avn cubriessen las gargantas $>y$ las casadas trayan toca larga y con punto desde el dia en que casauan<. Mas ya con (fol. 167v) grand dissolucion, perdida toda verguença, hasta el estomago descubren las que son desonestas ${ }^{94}$, /porque no digamos hasta el vientre/, a las quales podria y deuria cada vno dezir con el propheta: cobrid por Dios vuestras verguenças, que confusion -como dize el psalmocubrió mi cara en verlas.

[53] Capitulo V95. Demuestra que tanbien es cosa natural que de vna manera se vista el varon y de otra /manera/ la hembra, y que generalmente cada vno sea vestido >como es menester< para bien executar su of/f/icio.

[54] Tanbien es cosa natural, y por esso vsada en toda parte, que de vna manera se vista el varon y de otra >manera se vista < la muger, y que generalmente $>$ que $<$ cada vno traya el vestido, segund que más conuiene -44v-para la execucion de su of/f/icio.

[55] Porque comunmente las mugeres están y fueron hechas para estar ençerradas ${ }^{96} \mathrm{e} \mathrm{oc/c/upadas} \mathrm{en} \mathrm{sus} \mathrm{casas} \mathrm{y} \mathrm{los} \mathrm{varones} \mathrm{para} \mathrm{andar} \mathrm{e}$ procurar las cosas de fuera, por esso a donde quier que ay seso ${ }^{97}$ se vsa que ellos trayan roba corta y ellas ropa lu(fol. 168r)enga. Ca para andar acá y allá por el poluo y por el lodo es menester 98 /ropa corta y/ hábito corto, y bien por esta causa los clerigos y los letrados, e los onbres ançianos y honrrados, en toda parte tra/h/en y siempre traxeron hábitos largos. $\mathrm{Ca}$ el of/f/icio de aquestos más es de estar $y>$ de $<$ vacar a obras intellectuales

$91 \mathrm{Ms}, 43 \mathrm{v}$ : que no es necessario que anden descubiertas assy como a los varones y aun a las mugeres traher cubiertos los pechos, que no hay necessidad por que deuan andar descubiertos, saluo a las mugeres que crian que han de tener ligeras de sacar las tetas para las dar a las criaturas que han de amamantar.

$92 \mathrm{Ms}, 43 \mathrm{v}$ : otro tiempo.

$93 \mathrm{Ms}, 43 \mathrm{v}$ : cobriese.

94 Ms, 44r: se descubren algunas mugeres fasta el estomago.

$95 \mathrm{Ms}, 44: 2^{9}$.

$96 \mathrm{Ms}, 44 \mathrm{v}$ : encarceradas.

$97 \mathrm{Ms}, 44 \mathrm{v}$ : por esto en toda parte se usa que.

$98 \mathrm{Ms}, 44 \mathrm{v}$ : menester es. 
que $>$ de $<$ andar mucho solicitos en procurar cosas temporales ${ }^{99}$. Claro es que el que ha de correr o luchar, o trocar o cauar, o texer o carpentear, o trepar o hazer obras 100 semejantes otro hábito más expedido ha menester que el que está rezando, $-45 r$ - o leyendo o escriuiendo, o brosiando o haziendo lotra/ qualquier obra de reposo $y>d e<$ assossiego. $E$ avn porque la honestad y verguença ha de ser mayor en las personas ec/c/lesiasticas y en las mugeres que en los seglares $>y$ en los $<$ varones $>$ por esso los clerigos $y$ mugeres tra $>h<e n$ y han de tra $>h<e r$ ropas luengas que cubran pies e piernas y no tanto los varones<. La graueza, seso y madureza ha de luzir en los ec/c/lesiasticos y en los letrados y en los ancianos - como dizen los sabios-e por esso 101 han de traer luengos y ponposos habitos. $Y$ avn para refrenar la lige(fol. 168v)reza que naturalmente tienen las mugeres fue cosa natural que trax/i/essen ropa luenga que las pudiesse enpachar.

[56] Capitulo sesto 102. Demuestra que tanbien es cosa natural 103 que el varon traya la cabeça descubierta, saluo por necessidad, y $>$ que $<$ la muger $>$ la traya $<$ cubierta. $-45 \mathrm{v}-$

[57] Tanbien 104 es cosa natural que el varon traya la cabeça descubierta, saluo por necesidad, >y que la muger siempre la traya cubierta $<$ por dar a entender que >e<l varon -como dize el Apostol- es cabeça de la muger, y que ella es y ha de ser subjeta ${ }^{105}$ al varon y regida e gouernada por él, e no el varon por la muger. $Y$ avnque >aqu<esto dize el texto del $\mathrm{Ge}$ nesi que le fue dado en pena pero todavia, segund su condicion natural, auia de ser subjeta 106 avnque no por aquella manera, ca fuera lo degradó e no en tantas cosas como agora lo es y $/ \mathrm{lo} /$ ha de ser, quiera o no quiera.

[58] En tanto conosció la Santa Rebeca que la muger, especialmente casada, es obligada a cobrir la cabeça (fol. 169r) en señal de subjecion ${ }^{107}$, que dize el texto que quando la trayan para el patriarcha Ysaac, su marido, luego que le 108 vio en el campo, descendió del camello en que venia cauallera e cubrió -46r- con el manto su cabeça.

\footnotetext{
$99 \mathrm{Ms}, 44 \mathrm{~V}$ : en expedir las corporales.

$100 \mathrm{Ms}, 44 \mathrm{v}$ : cosas.

$101 \mathrm{Ms}, 45 \mathrm{r}$ : por to qual.

$102 \mathrm{Ms}, 45 \mathrm{r}: 3^{\mathrm{0}}$.

$103 \mathrm{Ms}, 45 \mathrm{r}$ : que es tanbien cosa natural.

104 Ms, 45v: Iten.

$105 \mathrm{Ms}, 45 \mathrm{v}$ : subiecta.

106 Ms, 45v: subiecta.

107 Ms, 45v: subiection.

$108 \mathrm{Ms}, 45 \mathrm{v}$ : 10.
} 
[59] Esto dize el Apostol que nos enseñó y enseña la naturaleza: que a las mugeres proueyó de cabelladuras luengas con que andouiessen cubiertas, e no assi a los varones, onde el vso comun tiene que ellas crien los cabellos e los trayan luengos, y que los varones los corten e non se precien dellos. Y assi dize esse mesmo apostol que es tanta fealdad y mengua al varon, e tanto contra natura e >contra $<$ razon, criar y aleznar el cabello e tra $>h<$ erlo luengo $>0<$ con col $>\mid<e t a$, como seria a la muger andar toda trasquilada $y$ tra $>h<e r$ la frente y el colodrillo de fuera.

[60] Uerdad es que en otro tiempo mandaua Nuestro Señor que ${ }^{109}$ los varones de su pueblo /que/ no >se < cortassen el cabello, mas aquello era quando les mandaua juntamente que no hiziessen la barua, lo qual se hazia todo por euitar y desechar la loçania e dis-46v-solucion de los gentiles ydolatras, que a (fol. 169v) hon>r<ra de sus dioses trayan trasquilado o cercenado el cabello e /avn/ rapada la barba e avn algunos toda la cabeça ${ }^{110}$, segund que lo dize Baruch propheta.

[61] $E$, por nos dar a entender que cessando la ydolatria deuia ce/s/sar aquello, dize despues >Nuestro Señor < por Ezechiel propheta que no raerán la cabeça ni criarán 111 colleta, mas que trasquilarán o cercenarán el cabello, lo qual es profetizado ${ }^{112}$ de aqueste presente tienpo. Avnque muchos de los seglares, escuderos, /labradores/ e of/f/iciales, en $\mathrm{gran} / \mathrm{d} /$ denuesto de su estado $>$ e no $\sin$ pecado<, han peruertido e corronpido /y no syn peccado/ peruierten e corronpen aquesto.

[62] Capitulo VII 113. Demuestra que naturalmente se mudan las vestiduras $y$ >el< calçado segun/d/ que se mudan lo tiempos del año.

[63] Aun es cosa natural, o como natural $>y<$ vsada en toda parte $e$ lugar, que -47r-se muden las vestiduras segun/d/ que se mudan los tienpos. $\mathrm{Ca}$ a/s/si como vsamos vnas >vestiduras < en verano e otras en inuierno, assi vsamos e deuemos vsar vnas en tienpo de tristeza, de lloro e de aduersidad, e otras en tiempo de alegria, de gozo y de prosperidad.

[64] $Y$ de aqui es (fol. 170r) lo que leemos en la San/c/ta >E<scriptura: que los que auian tristeza e mostrauan ${ }^{114}$ sentimiento de dolor, tanbien los judios

\footnotetext{
109 Ms, 46r: a.

$110 \mathrm{Ms}, 46 \mathrm{v}$ : la cabeça toda.

111 Ms, 46v: traerán.

$112 \mathrm{Ms}, 46 \mathrm{v}$ : prophetado.

113 Ms, 46v: IIII\%.

114 Ms, 47r: auian.
} 
como los gentiles ${ }^{115}$, rasgauan sus vestiduras etc. $/ /$ de aqui es que los vnos e los otros leemos que en tienpo de penitencia $e>d e<$ af/f/lic/t/ion vestian sacos de sayal y derramauan ceniza sobre sus cabeças. $Y$ de aqui es que los religiosos de qualquier orden que sean, saluo las de los caualleros, traen e han de traer hábitos de paño vil, aspero e despreciado, porque tienen of/ficio y estado de hazer penitencia por sus -47v-pe/c/cados e por los del pueblo; y avn las religiones de los caualleros quieren que no vistan sedas ni mucho menos brocados, ni>n< avn todos colores de paños, mas solamente los honestos.

[65] Capitulo VIII 116. Demuestra como en el vestir e calçar es algo o mucho voluntario, y como en esto que es voluntario acae $>$ s<ce muchas vezes errar y pec/c/ar.

[66] Voluntario es en la vestidura ${ }^{117}$ que sea de lino o de fustán, 0 de fusteda $/ o /$ de cuero o $>$ de $<$ paño, /o/ de oro o $>$ de $<$ seda, tanbien es voluntario que sea (fol. 170v) sin pliegues o plegada, de tal o del tal manera /obrada/, y ${ }^{118} \mathrm{de}$ tal $\mathrm{o}>\mathrm{de}<$ tal aforro af/f/orrada /y assi mesmo en la compostura/.

[67] $Y$ en esto que es voluntario acaece muchas vezes /errar $y /$ pec/c/ar venial o mortalmente, segun/d/ que más o menos la persona se aparta y excede o fallece de lo natural y ${ }^{119}$ necessario. -48 r- Ca no es otra cosa pe/c/car generalmente hbalando (sic) sino apartarse ombre poco o mucho de lo >que es< natural y segund razon ordenado, y si mucho se aparta pec/c/a mortalmente $>\mathrm{y}<\mathrm{si}$ poco venialmente. Por manera que a/s/si como en el comer y beuer pec/c/a mortalmente o venialmente el que mucho o poco excede o fallece de lo necessario y razonable ${ }^{120}$, bien assi es en el vestir e componer.

[68] Capitulo IX ${ }^{121}$. Que el comer e vestir andan y deuen andar por vna manera o por vna regla ${ }^{122}$.

$Y$ paresce claramente que el comer y vestir andan quasi por vna manera, porque Nuestro Redenptor y maestro, $>$ muy perfeto $<$ Jesuchristo ${ }^{123}$, lo $>S<$

i15 Ms, 47r: tambien judios como gentiles y gentiles como judios.

$116 \mathrm{Ms}, 47 \mathrm{v}$ : quinto.

$117 \mathrm{Ms}, 47 \mathrm{v}$ : en la vestidura es.

118 Ms, 47v:o

119 Ms, 47: 0 .

$120 \mathrm{Ms}, 48 \mathrm{r}$ : excede de lo necessario o fallece dello.

121 Ms, 48 r: sexto.

$122 \mathrm{Ms}, 48 \mathrm{r}$ : andan quasi por vna manera o regla y deuen andar.

$123 \mathrm{Ms}, 48$ r: Ihesuchristo. 
juntó en el /Sancto/ Euangelio quando fabló de aquel rico malauenturado que fue sepultado (fol. 171r) en el infierno; ca dize al comienço de >aquel<la historia y semejança que aquel miserab>i<le rico se vestia de purpura y de bisso, y comia cada dia -48v- costosamente.

[69] $Y$ avn es razon que el comer $y>$ >el< vestir >se junten $y<$ sean de 124 vna manera porque ambas cosas son las primeras que son más necessarias para conseruar la humanidad, como fue arriba tocado 125 /en la sententia del sabio ecclesiastico/; y assi se suele dezir que o vistamos como comemos o comamos segund que vestimos $126 /$ si buenamente podemos/.

[70] Capitulo decimo ${ }^{127}$. Que tan bien ay en el comer y beuer voluntario y natural como en el vestir y calçar.

[71] Tan bien hay en el comer y beuer voluntario y natural como en el vestir y en el calçar/. Cosa es natural y mucho razonable comer y beuer quanto es ${ }^{128}$ menester para que el cuerpo biua sano, y que en ello aya diuersidad en quantidad $>y$ en qualidad $<$ segund que las personas son diuersas en las complessiones y en las edades, y en los officios y exercicios, y avn segund que los -49r-tiempos son diuersos. Ca el varon ha menester mayor ${ }^{129}$ mantenimiento que la muger porque (fol. 171v) tiene más caliente complexion; y más >ha menester< el mancebo que el viejo por essa mesma razon especialmente en tanto que cresce. porque entonces es menester mantenimiento no solamente para conseruar e sostener mas tanbien para crescer; y más > han menester < los que trabajan corporalmente que los que obran con el spiritu solamente, y aquéllos más rezias y >más< gruessas viandas y aquéstos más sotiles y delicadas.

[72] $Y$ en verano son más naturales algunas, como las fru/c/tas verdes y agras y avn viandas más delgadas, y otras >son< más naturales en lel/ inuierno como las fru/c/tas secas e dulces e más gruessas viandas. Porque quanto el calor del estomago está más recogido adentro por causa del tiempo frio tanto está más fuerte e más rezio, y en el verano más flaco porque está más espar-49v-zido. $Y$ es cosa natural y razonable que en tiem-

$124 \mathrm{Ms}, 48 \mathrm{v}$ : por.

$125 \mathrm{Ms}, 48 \mathrm{v}$ : apuntado.

$126 \mathrm{Ms}, 48 \mathrm{v}$ : assi se usa comunmente, que como uestimos comemos y segund que comemos uestimos.

127 Ms, 48v: septimo.

$128 \mathrm{Ms}, 48 v$ : lo que es.

129 Ms, 49r: mas. 
po de penitencia, de af/f/lic/tion y de aduersidad vsemos de viandas pobres y des/s/abridas con que el ${ }^{130}$ cuerpo sea af/f/ligido, y avn en tienpo de (fol. 172r) sterilidad y de mengua es cosa muy razonable que tengamos más la rienda.

[73] Capitulo vndecimo 131. De como Nuestro Señor Dios nos enseñó que 132 en el comer y beuer/h/ay y deue auer muchas dif//erencias y diuersidades naturaies apuntadas en el capitulo precedente.

[74] Todo esto nos enseñó Nuestro Señor, criador y gouernador de la naturaleza, cuya prouidencia, como sea infinita, non se extiende al cielo solamente ${ }^{133}$ como algunos pensaron e piensan, mas tanbien al mar y a la tierra, y a todas las cosas que en ellos son. Ca él crió, proueyó y ordenó ${ }^{134}$ que en el verano ouiesse las fru/c/tas verdes humidas e tiernas, e las carnes nueuas, as/s/i de las aues que entonce sacan pollos como -50r- de las vacas e ouejas, y de todas las otras animalias que vsan comer los onbres; $y$ $>$ que $<$ para el inuierno >ouiesse $><$ las $>$ fru/c/tas secas de nuezes $>y<$ almendras, auellanas, vellotas $>y<$ castañas, e /aun/ algunas verdes que concuerdan con ellas, como los madroños y las ser(fol. 172v)uas, /peros reales y mançanas, camuesas, etc./ y para el inuierno las carnes cre/s/cidas y hechas, tanbien de las aues como de las quatropeas.

[75] O marauilloso Dios, muy poderoso, muy sabio y muy piadoso criador/y gouernador/, que as/s/i proueyó de la leche, que es manjar mucho tierno a 135 todos los animales rezién na/s/cidos, y que cessasse aquella vianda naturalmente y se enxugassen las tetas en todas las madres y hembras desque los tales animales touiessen fuerça $>\mathbf{s}<$ para tomar ${ }^{136}$ viandas rezias. Su prouidencia ordenó y expressamente mandó -50v-que ante/s/ del Diluuio comiessen los ombres fru/c/tas solamente, que son de menos gouierno y de más rezia digestion, porque entonce $>$ s $<$ tenia el ombre más rezia y más sana complession, y por esso biuian muy luengo tiempo. Mas despues del Diluuio dio licencia para comer carne y inspiró a No $>$ h<é que plantasse y labrasse viña, como hasta alli non ouiessen sabido qué cosa era vino ni >avn< sidra ni seruicia (sic) mas solamente ${ }^{137}$

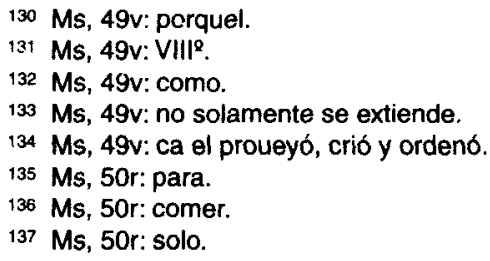


buena agua /limpia/. Y esto >otorgó< porque la haz de la tierra perdió mucha de su virtud, ca las aguas saladas del Mar Oceano salieron enton(fol. $173 r$ ) $c e>s<$ de madre e andouieron por toda la tierra, y le ${ }^{138}$ consumieron /y gastaron/ y estragaron la virtud e grossura de la haz e costra de $>$ e $<$ ncima que criaua las fructas mas gruessas e mas çumosas, mas tiernas e mas prouechosas.

[76] >ltez (sic), lo otorgó> porque la conplexion humana parece que -51r- se enflaque>s<ció, y assi la vida 139 se /di/minuyó a no $>n<$ passar si no $>n<$ por marauilla de cient años ar $>r<i b a$ y avn - como dize el psalmo-, los que passan de ochenta tienen harto trabajo. Uerdad es que veemos 140 por experiencia que los religiosos e varones santcos (sic) que non comen -5iv- carne y más se dan a la abstinencia aquellos biuen más sanos e avn más años. Segun que ${ }^{141}$ se lee que el santo Dariel propheta ${ }^{142}$ e sus >religiosos< conpañeros fueron mejor mantenidos e más rezios y efforçados con las legunbres $/ y /$ con el agua e con el pan baço que los otros donzeles del rey a los quales eran ministradas viandas costosas e más sabrosas e a lo comun para efforçar más prouechosas.

[77] En es/s/e mesmo /tiempo del/ Diluuio, que fue tiempo de af/f/lic/t/ion y de graue penitencia, ordenó Nuestro Señor que avn las aues $y$ (fol. 173v) bestias que biuen de rapina y no saben comer syno carne hiziessen abstinencia. Ca puestas en la arca con el patriarcha Noé les dio por vianda fru/c/ta $>s<$ seca $>s<$ solamente y les suspendio y ató el des/s/eo natural que tenian de las carnes, y les quitó toda enemistad, por manera que estauan jun $>c<$ tos el açor y la perdiz, el nebli y la garça, el galgo y la liebre, el podenco y el conejo, el lobo y el cordero, el gato y el perro, y todos tenian paz y comian de vna vianda ${ }^{143}$ como si fueran todos de vna ralea, de vna le/specie y de vna casta.

[78] Fue aquello grand miraglo 144 de Nuestro Señor hecho, no sin grand misterio, $y$, avnque salga del proposito, es $>$ muy $<$ bueno $>d e<$ saberlo. Ca nos quiso dar a entender que despues que viniesse al mundo el perfecto saluador thesuchristo, Nuestro Redemptor -entendido por Noé-, el qual mediante el precioso madero de la sancta cruz /en que padeçio/ - figurado por aquella archa - libró al linaje -52r- humanal del Diluuio e abundancia de los pe/c/cados, quebrantando el poder de Sathanas e dando abundancia de

\footnotetext{
$138 \mathrm{Ms}, 50 \mathrm{v}$ : por toda ella y la.

139 Ms, 51r: por lo qual la vida.

$140 \mathrm{Ms}, 51 \mathrm{r}$ : Avunque veemos.

141 Ms, 51r: como.

142 Ms, 51r: propheta Daniel.

143 Ms, 51v: y todos comian de vna vianda y tenian paz.

144 Ms, 51v: Miraglo fue grande.
} 
gracia y de caridad >para< con que más ligeramente puedan ser euitados todos te $>$ r $<$ nian mucha paz (fol. 174r) e concordia avnque antes fuessen contrarios; $y$ todos ternian vnos sacramentos los que entrassen en el corral y red de su san/c/ta fe -entendido por aquella arc $>h<a$ del sancto Noé - porque todos entran en la fe de Dios crucificado, y re>s<cibiendo la agua del sancto baptismo en nombre de la San/c/ta Trinidad, padre >e< hijo e Spiritu Sancto, signados con el tau de la sancta cruz, hecha por esso con tres dedos consu/b/stanciales en vna mano, avnque es /muy/gran/d/ di/f/ferencia de Trinidad a Trinidad, y de vnidad a vnidad.

[79] Porque en los dedos no tiene el vno la su/b/stancia del otro en numero, -52v- mas en specie ${ }^{145} \mathrm{y}>\mathrm{en}<$ semejança >solamente<, y por esso ${ }^{146}$ pereciendo vn dedo ${ }^{147}$ no perecen los otros, y avn obrando vn dedo ad extra no >es necessario que junctamente obren< los otros >con él ${ }^{148}$. Lo qual todo no es assi en aquella Santissima Trinidad y vnidad, como bien saben los que dello más saben<.

[80] Al que la paz ${ }^{149}$ y concordia y vnidad de sacramentos, que son mantenimientos de las almas, fue profetizada por Ysaias quando dixo que venido 150 el Messias morarian en vno el lobo y el cordero, $>\mathrm{y}<\mathrm{la}$ onça y el cabrito, el leon y /la/ oueja y el be(fol. 174v)zerro, y que los guardaria e regiria 151 vn moçuelo pequeñuelo, y que el bezerro y el osso pacerian de consuno e holgarian en vno sus hijuelos, y que el leon comeria paja $>$ s < como buey etc. Lo qual a/s/si a la letra nunca se cumplio ni>n< complira, mas veemoslo complido e complir de cada dia quanto a la spiritual intelligencia en el pueblo christiano de gentiles e judios ayuntado, que eran primero ${ }^{152}$ contrarios como gat $>\mathrm{k}<0$ e perros, e como lobos e -53r-corderos. $N /$ especialmente se cumple en las san/c/tas religiones donde todos son ${ }^{153}$ yguales en vestido y en mantenimiento y en otras muchas cosas los grandes y los menores, los buenos e los mejores.

[81] Iten, porque en tiempo desterilidad e >de< pobreza deue auer otra manera en tomar el mantenimiento ${ }^{154}$. Por esso el sancto viejo Thobias se marauillaua quando estaua pobre e ciego ${ }^{155}$ que su buena muger le tra-

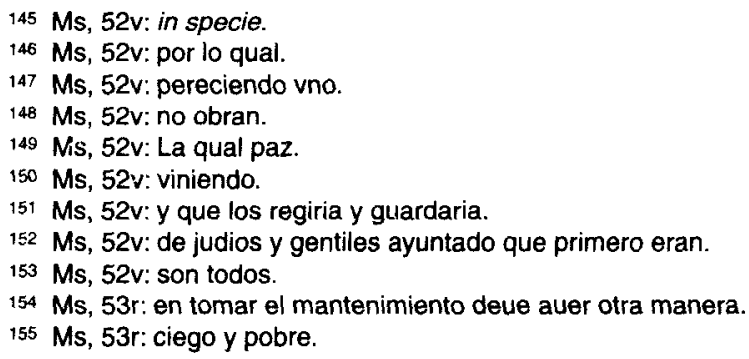


xiesse cabrito para comer. $\mathrm{E}$ assi dizia el sancto Job que las viandas despreciadas que estando prospero, rico y abastado no queria gustar, venido a mengua y a pobreza aquéllas eran su manjar. Pues (fol. 175r) todo lo susodicho pare $>s<c e$ natural >en el tomar del mantenimiento como era natural< lo que 156 fue dicho primero del vestir y del calçar.

\section{[82] Trercera parte./}

Capitulo XII, /I desta tercera parte/. De/muestra/ la primera manera en que >a<conte>s<ce pe/c/car en el vestir y >en el< calçar, assy como >en el< tomar del 157 mantenimiento, >que es< quando se toma o se trahe ${ }^{158}$ en demasiada quantidad.

[83] -53v- Agora, pues que $>e<1$ tomar del mantenimiento, y el vestir y >el< calçar se han por vna manera, es de saber que en tomar el mantenimiento pecamos no tomando quanto es menester, avnque esto acaesce pocas vezes, e muy muchas vezes tomando de más ${ }^{159}$. /Especialmente excedemos en çinco maneras/. Conuiene /a/ saber: tomando/lo/ en demasiada quantidad, en vna vez o en muchas; y queriendo viandas costosas y exquisitas ${ }^{160}$; iten, queriendolas mucho adobadas, avnque de suyo sean viandas despreciadas; e tomandolas otrosi no en tienpo deuido; $y$ tomandolas con grand $>\mathrm{e}<$ ardor y deleyte. $>$ Pues $<$ en semejantes maneras acontece falle $>$ s $<$ cer y exceder en el vestir e conponer.

[84] Lo primero vistiendo en demasiada quan(fol. 175v)tidad, en vna vez o en muchas. Digo demasiada quantidad en vna vez quando alguna persona, varon o muger, viste juntamente demasiadas vestiduras, o en el numero dellas o en el -54r-tamaño y 161 en las longuras: /Como quando alguno trae juntamente jubón, sayo y balandrán, o camarro y capapuz o manto, bonete y sombrero, y guantes de nutria encima y debaxo de rebeço, e cinta y cinto, y aun cintero y calças con pies y seruillas, y auanpies, borzeguies y çapatos, y más alcorques o çuecos, y aun forrados los alcorques en paño o en seda/. Y cresce la demasia quanto es más luengo y más complido 162 de lo necessario y de lo que razonablemente bastaria /a cada persona segun su condicion y estado. $Y$ assy quando la

156 Ms, 53r: lo qual.

157 Ms, 53r: el.

$158 \mathrm{Ms}, 53 \mathrm{r}$ : quando esto se haze en demasiada.

$159 \mathrm{Ms}$, 53v: en tomar el mantenimiento aconteçe fallecer, aunque pocas vezes y muy muchas exceder.

$160 \mathrm{Ms}, 53 \mathrm{v}$ : exquisitas y costosas.

$161 \mathrm{MS}, 54 \mathrm{r}: 0$.

$162 \mathrm{Ms}, 53 \mathrm{v}$ : Ca todo es demasiado e non sin peccado lo que excede. 
dueña visten faldetas, fasta tres pares dellas, y saya, brial o sobresaya, y faxa y cintero y cinta, y ropa, aliuba (sic), o balandrán mongil o tauardo, y manto seuillano o lombardo, y muchas tocas con grande y grandes telas de lienço en el tocado, y mangas de más de vara en ancho. $Y$ cresce tanbien en esto la demasia y el peccado quando sin prouecho -54v-alguno anda todo ello por el suelo arrastrando, especialmente quando trayan faldas que auian menester poco menos cherrion para leuarlas/. Y avn no es sin peccado traer chapines muy altos 163 que hazen crescer la costa $e$ quantidad del paño, >demas de ser pecado de soberuia y de mentira, ca se fingen con ellas y se muestran luengas las que de suyo son pequeñas, e quieren emendar a Dios que hizo a las mugeres de menores cuerpos que a los onbres ${ }^{164}<$.

[85] En muchas vezes acontesce 165 vestir demasiado quando todo lo susodicho tienen o querrian tener doblado $>0$ trasdoblado<, non solamente vno para el inuierno e otro para el verano, e vno para en $>$ las < fiestas e otro para en cutiano ( $\mathrm{sic}$ ), que avn esto podria >muy< bien passar tanto que fuesse templado, mas tienen para mudar cada mes e cada semana, e >avn < cada dia e cada ra(fol. 176r)to. Cierto es que ay personas que no se contentan de salir a las bi/e/speras con las ropas e vestiduras ${ }^{166}$ que $>\mid<$ leuaron a las missas, e no porque en el tiempo -55r- ouo mudança ni >porque ouo < necessidad de hazerla sino por apetido (sic) de vestir demasiado, como el que almuerza y merienda y haze muchas colaciones e comidas sin auerlo necessario.

[86] Tener vestiduras sobradas, y en la percha o en el aparador guardadas, ayudó e dio grand causa a que Esau perdiesse la bendicion. Ca dize el texto que vistio Rebeca a Jacob, para que mejor engañasse a su padre, vestiduras de Esau muy buenas que ella tenia guardadas ${ }^{167}$; y eran tales que quando el san/c/to patriarcha Ysaac, padre de ambos, sintió el olor suaue dellas luego se encendió en deuocion e començó a bendezir diziendo: he el olor de mi hijo como olor de campo lleno al qual bendixo Nuestro Señor. Esta demasia de vestiduras con otros dones rehusó e no quiso recebir el propheta Heliseo de Naaman, príncipe de Siria, quando le sanó de la $-55 v$ - graue lepra que padecia ${ }^{168}$. (fol. 176v)

$163 \mathrm{Ms}, 54 \mathrm{v}$ : trayendo otrosi chapines de codo en alto.

$164 \mathrm{Ms}, 54 \mathrm{v}$ : Lo qual todo es tanto mayor peccado quanto mas excede de la necessidad y honestad natural de lo medido y ordenado.

$165 \mathrm{Ms}, 54 \mathrm{v}$ : acaesce.

166 Ms, 54v: vestido.

167 Ms, 55r: en guarda.

$168 \mathrm{Ms}, 55 \mathrm{v}$ : tenia. 
[87] Capitulo XIII 169. Demuestra que >e<I tal excesso es peccado de soberuia, contrario a la humildad que es vna de tres virtudes, que en el vestir e calçar tienen el medio e guardan la honestad, $y$ avn demuestra que el tal excesso tanbien es pe/c/cado de auaricia y de rapina.

[88] Todo lo sobredicho es peccado de soberuia, que es contrario a la humildad del uestir. $\mathrm{Ca}$ / dizen los sanctos, y es verdad, que son entre otras tres /principales/ virtudes que en el vestir e conponer tienen el medio e guardan la honestad. /Y/ éstas /dizen que/ son: humildad, per se su/f/ficiencia e simpleza, assi como en el comer y beuer ponen freno e tienen medio sobriedad e abstinencia. > La humildad refrena de toda jactancia < e vanagloria 170 que mueue /a/ las personas a vestir demasiado. De la segunda e tercera diremos adelante en sus -56r- prop/r/ios lugares.

[89] Es otrosi lo susodicho peccado de auaricia y de rapina, porque el que viste demasiadas ropas retienelas e robalas, como dizen muchos san/c/tos, a los que las han necessario. Ca dize sant Basilio: como Dios, Nuestro Señor, dispense e distribuya todos los bienes, (fol. 177r) e no $>n<$ sea injusto repartidor nin a/c/ceptador de personas, ¿por qué piensas que quiso que tú touiesses mucho $\mathrm{y}>$ que $<$ aquél mendigasse, sino por que tú mereciesses buen galardon despendiendo y partiendo liberalmente la abundancia que te puso en poder, y porque aquel menguado mereciesse /otrosi/ auiendo buena paciencia en el non tener? Pues del hambriento es el pan que a ti sobra, y del desnudo la vestidura que puedes excusar, y del descalço el calçado que no has menester, y del menest/e/roso la plata y el oro que tienes en thesoro, $y$ a tantos robas -56v- $y$ injurias a quantos menesterosos no comunicas lo que podrias.

[90] San Ambrosio dize esto mesmo avnque por otras palabras, y añade que no es menor pe/c/cado al que tiene /de/ no socorrer a los que no $>n<$ tienen que tomar a los que tienen.

[91] Cosa descomulgada ${ }^{171}$ dize el Apostol que es, e por tal la ${ }^{172}$ conde $>p<n a$, que vnos estén hartos e otros mueran de hambre. $E$ assi >es cosa muy desordenada< que vnos /cansen y suden por/ esten 173 demasiadamente calçados y vestidos, e que otros por mengua desto anden desnudos e mueran de frio. Cuenta muy estre $>c<c h a$ dize Ihesuchristo que (fol. 177v) le auemos de dar dello en el Dia del Juyzio. E no digo aqui más de >aque<sta

\footnotetext{
169 Ms, 55v: \|\|$^{2}$.

$170 \mathrm{Ms}, 55 \mathrm{v}$ : y vanagloria.

$171 \mathrm{Ms}, 56 \mathrm{v}$ : Descomulgado dize.

$172 \mathrm{Ms}, 56$ : lo.

$173 \mathrm{Ms}, 56 \mathrm{v}$ : estar.
} 
materia porque no fue introduzida sino $>n<$ para manifestar como es $\mathrm{pe} / \mathrm{c} / \mathrm{cado}$ de auaricia y de rapina tener e traer demasia de vestiduras. $Y$ esto sea quanto a la primera manera que acaeçe peccar y exçeder -57r- en el uestido y en el calçado, assi como en comer y beuer demasiado/.

[92] Capitulo XIIII ${ }^{174}$. De la segunda manera >en< que en el vestir e calçar, assy como en comer y beuer acae $>s<c e$ peccar.

[93] Es la segunda manera vistiendo e calçando cosas de mucho valor e costosas, por via que avnque la ropa no sea más de vna, y ni sea luenga ni corta >mas mesurada e justa<, es excesso ${ }^{175} \mathrm{y} \mathrm{pe/c/cado} \mathrm{si} \mathrm{>segund}$ su estado< es /cosa/ mucho costosa. En lo qual otrosi suelen ${ }^{176} /$ mucho/ las $^{2}$ personas exceder por soberuia e por deleyte, assi como en el comer y beuer. Ca muchos no comen ni beuen en mayor quantidad ni más vezes de lo que deue/n/ pero quieren e comen y beuen viandas e vinos costosos, e $>$ avn $<$ a/s/si suelen dezir que quieren poco e bueno ${ }^{177}$.

[94] En esta manera de vestir y de tra/h/er y avn aosadas de comer y de beuer exceden >comunmente< muy muchas ${ }^{178}$ personas de todos (fol. 178r) /los/ estados en este nuestro tiempo, porque cada labrador $e$ cada of/f/icial, cada escudero, /y/ -57v- cada cibdadano y cada cauallero de pequeño y de ${ }^{179}$ grande estado excede manifiestamente $>$ no de lo natural solamente, mas avn< de lo que es permisso e to $>$ |<lerado $>$ a $<$ cada vno segun/d/ su estado. Quan mala ${ }^{180}$ parece - solian dezir al villano- la manga prieta en el braço, mas ya no /h/ay pobre labrador ni of/f/icial por marauilla que no viste fino paño ${ }^{181}>$ y avn seda que es más. $<$ En los escuderos e ombres de honor 182 botas e gauán solian /en/cobrir mucha lazeria, mas ya ni ${ }^{183}$ basta paño fino ni seda. As/s/i que en >aqu<esta parte toda carne ha corrompido su manera, y tanbien en los a/f/forros, que si pueden auerlos de grises o de martas no se contentan que sean de peña; el sayo o manto viejo solia/n/ seruir para a/f/forrar lo nueuo, mas agora tanto ${ }^{184}$ más vale el af/f/orro que la haz.

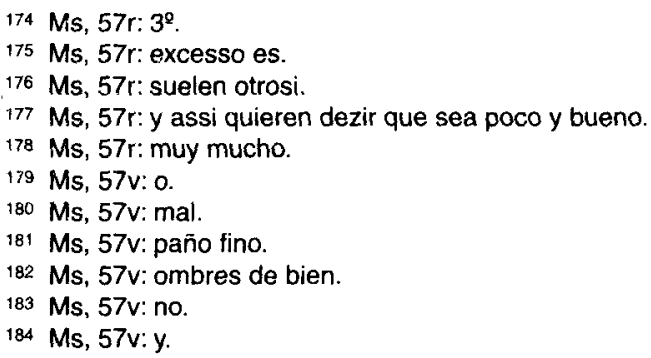


[95] /Pues/tanbien pecan las >tales $<$ personas que assi exceden /en/ pe/c/cado de soberuia 185 si por jactancia e 186 vanagloria se -58 - mueuen, e por pujar e parecer mayor, o a lo menos no menor >cada < vno que >el $<$ otro.

[96] Pec/c/an otrosi pec/c/ado de mollicie y desobrado deleyte si se mueue $>n<$ a exceder por el pla(fol. 178v)zer que han de ver la fineza del paño o de la seda, o por el deleite que reciben de la blandura della. $Y$ a/s/si dezia Nuestro Redemptor ${ }^{187}$ alabando a Sant Juan 188 de las asperas vestiduras, que los que se visten de $>$ vestiduras blandas $y<$ muelles son en las casas de los reyes. $>\mathrm{Y}<$ en esta manera se excede mucho en las olandas e finas bretañas $y>e n<$ otros lienços costosos, como por el contrario nuestra mezquina e mala carne ouiesse menester de andar siempre cercada y espinada de vestiduras asperas ${ }^{189}$. O bienauenturada Cecilia sancta e muy noble $>$ donzella<, que avnque encima traya paño fino e rica seda por complir con el estado pero acerca de la carne traya de continuo cilicio $190 / e$ no lienço delgado/. Esso mesmo se lee de la san/c/ta dueña Judic $>h<$, y de algunos sanctos caualleros que .58v- andauan en el palacio, assi como Sant Martin, Sant Sebastian, Sant Pablo e Sant Juan 191 en tiempo de Gallicano.

[97] Item de San/c/to Thomas, arçobispo de Cantu/a/ria, e de otros san/c/tos prelados se lee que trayan cilicios y asperas vestiduras de monjes debaxo de aquellos hábitos honrrados ${ }^{192}$. Y avn del rey Jorán se lee que en el tiem(fol. 179r)po que estaua cercado en la cibdad de Samaria traya cilicio a carona de la carne ascondido e cubierto con la vestidura real que traya encima.

[98] De pieles de animales vistio Dios a nuestros primeros padres como los pudiera sy quiera vestir de rico brocado. $>Y<$ assi dize el texto que les hizo tunicas de pellejas y llamó a aquellas vestiduras tunicas, que propiamente quiere dezir to $>n<$ gas o sayas que hazen sonido cada que son tra/c/tadas y 193 meneadas; donde pare>s<ce que no deuieran ser 194 de abortones o de corderinas muy delgadas, $\mathrm{ni}>$ guarnecidos $<$ de muy buenos baldreses, /afforradas o cin-59r-tadas/, ni con cote o cotes de garras perfiladas a las orillas 195 , mas quiçá crudas cuesqueras y desdonadas como las de los pastores, o >como las de los segadores o de otros pobres onbres $<$,

\footnotetext{
$185 \mathrm{Ms}, 57 \mathrm{v}$ : va tachado "o por deleite assi como en el comer y bever".

$186 \mathrm{Ms}, 57 \mathrm{~V}: 0$.

187 Ms, 58r: Nuestro Señor.

188 Ms, 58r: lohan.

189 Ms, 58r: espinada de abrojos.

190 Ms, 58r: pero a la carona traya cilicio de continuo.

191 Ms, 58v: Iohan.

192 Ms, 58v: de monjes por complir con los habitos honrrados.

193 Ms, 58v: o.

194 Ms, 58v: eran.

$195 \mathrm{Ms}, 59$ : a las orillas perfiladas.
} 
lo de aquellos carboneros que traen carbon a uender a Salamanca/. Uerdad es que despues 196 quiso que el sacerdote, especialmente mayor, vistiesse vestimentas de lino en ciertos dias y en otros de cierto paño e color, mas aquello todo era ${ }^{197}$ para significar cierto misterio que seria aqui luengo 198 de contar.

[99] La virtud que en esto refrena e ordena se llama per (fol. 179v) se sufficiencia. Ésta haze al que la tiene que se contente con lo necessario y razonable, $y>$ que $<$ no quiere ${ }^{199}$ ni traya lo costoso y demasiado, mayormente $>\mathrm{a}<$ cada vno segund su manera y estado.

[100] Aquesta segunda manera de exceder en el vestir y tra>h<er reprehende el /sancto/ apostol >Sant Pablo</diziendo que han de ser contentos los christianos con el uito y con el uestido. A do dize Sant Augustyn -59v- que no dixo con cibos y con uestimentos, que significan abundantia, mas dixo con uicto y uestito, que significan solamente lo necessario; y especialmente reprehende la demasia/ en las dueñas diziendo que no trayan oro ni perlas, ni vestiduras preciosas. Con el qual concuerda el apostol San/t/ Pedro dizyendo quasi essas palabras messmas 200 . Este excesso parece auer condem $>$ p $<$ nado Nuestro Señor quando a<s>sy penó al pueblo suyo por la vestidura de grana que con cobdicia guardó $>y$ abscondio< Achor, y quando priuó al rey Saul del reyno porque con cobdicia reseruó algunas vestiduras > preciosas< del rey Agab y de aquel 201 pueblo. $Y$ avn este mes $>S<m o$ excesso parece que reprehende y condena Nuestro Redemptor y maestro quando dize que aquel rico malauenturado que fue sepultado en el infyerno se vista de purpura y de bisso, que es lienço muy delgado, muy fino y muy blanco. Este excesso -60rdaña y reprueua el euangelista Sant Luchas quando, en los Actos de los Apostoles, re(fol. 180r)cuenta la muerte muy terrib>i<le y muy miserable de aquel maluado pomposo e soberuio/so/ Herodes, que para henchir su soberuia y vanagloria salio aquel dia a juzgar vestido de vestidura real y muy preciosa. $Y$ avn esto condenna Sant Juan 202 y denuest $>r<a$ (sic) en su Apocalipsi reprehendiendo e increpando a la cibdad de Babilonia y en aquélla ${ }^{203}$ a qualquier otra cibdad, villa o lugar que pe/c/ca en aquella soberuia /y uanidad/.

\footnotetext{
$196 \mathrm{Ms}, 59 \mathrm{r}$ : Saluo si alguno quiere dezir que despues.

197 Ms, 59r: Mas aquello fue.

198 Ms, 59r: luengo aqui.

$199 \mathrm{Ms}, 59 \mathrm{r}$ : quiera.

$200 \mathrm{Ms}, 59 \mathrm{v}$ : diziendo quasi estas palabras.

201 Ms, 59v: su.

$202 \mathrm{Ms}_{1}$ 60r: Iohan.

203 Ms, 60r: y so titulo de aquella.
} 
[101] Capitulo quinze ${ }^{204}$. De la tercera manera de peccar >en vestir y en calçar, y avn en comer y en beuer<, que es buscando mill maneras y nouedades de vestiduras $y>d e<$ trajes como en el comer muchos guisados adobados y potayes, /y espeçialmente pone algunas practicas de cómo en nuestros tiempos han excedido y exceden en aquesta manera los varones/.

[102] -60v- Lo tercero acae>s<ce pecar y exceder >en el comer y beuer $<$ no $>n<$ en $>l a<$ quantidad ni en ser costosas las viandas solamente, mas 205 en que sean adobadas y muy guisadas avnque de suyo sean ${ }^{206} \mathrm{co}-$ munes y de poco precio ${ }^{207}$, >ca a las vezes cuesta más el salmorejo que el conejo<.

[103] $\quad \mathrm{Y} /$ en esta manera pec<c>auan muchos de los judi(fol. 180v)os en el desierto quando Nuestro Señor les daua aquel celestial e miragloso mantenimiento, ca no se contentauan de le ${ }^{208}$ guisar simplemente mas >andauan $<$ catando maneras como mejor les supiesse. Bien assi /h/ay excesso grande $e>$ muy< comun en el tra $>$ h<er y en el vestir, ca dexado lo natural buscan las personas, varones e mugeres /de todo estado seglar/, mill maneras e nouedades de vestiduras $y>d e<$ trages, nouedades en los colores de muchas e diuersas maneras, muy agenas de la simpleza natural con que nos dan la lana las ouejas, la ${ }^{209}$ qual podria >a<bastar a/s/saz si la malicia humana se quisiesse contentar. Ca si Nuestro Señor mandó te-61r-ñir la pieles, coberturas e cortinas del tabernaculo y que $>e<$ sacerdote vistiesse tunicas jacintinas, todo aquello fue porque segun/d/ nuestra malicia no $>n<$ fuesse despreciado su oratorio y templo, e más principalmente ${ }^{210}$ por dar a entender en aquella manera grande y grandes misterios que están alli cubiertos. $E^{211}$ avn medio mal sería y allá $\mathrm{pa} / \mathrm{s} / \mathrm{sar} / \mathrm{i} / \mathrm{a}$ si con las mudanças e diuersidades de los colores fuessen los ombres contentos.

/Mas començando en los varones ya usan camisones bastillos, ya muy delgados contra la inuençion de la camisa, que fue hallada para dormir con ella o por más guardar la honestad o porque entonçe no se usauan sauanas; y assi dize Sant Ysidro, que camisa o camison tomó nombre de la cama. Ya los usan cortos ya muy largos, ya randados ya plegados. Ya los cabeçones como camisas de mugeres costosamente labrados. -61v- Ya usan

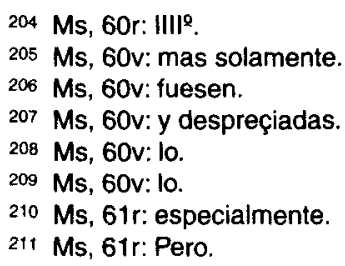


iubones de fustán, ya de fusteda, ya de seda ya de paño, y aun nuestro tiempo para poco se tiene quien no lo trae de brocado, como en otro tiempo solo el rey o cauallero de grand estado usasse traer brocado, ya todo de vn paño ya la meitad falsado. En el buen tiempo collar y puñetes eran de otro paño; los collares ya anchos y muy apartados y de muchos paños afforrados, ya iustos ya pegados y solamente engrudados. Las mangas ya enteras ya trencadas, ya cerradas ya abiertas, y las mangas de los camisones mucho sacadas, ya iustas ya buidas o fronzidas; ya los cobdos ya los ombros plegados, ya simples y sin braones, ya con ellos muy penosos, dañosos, costosos y deformes.

En los pechos vn tiempo cubricheles encordados con cordones, o con cintas como mugeres otro tiempo; y esto era mejor cubiertos -62r-con paletoques de puertas enteras o de medias puertas. Ya usan mantos o corochas, quando plegados quando maruetados, quando en los ombros golpeados, agora graçias a Dios llanos. Ya ropas, ya balandranes, ya gauardina, ya gauanes, ya lobas, ya tauardos, ya capas, ya capuzes, ya ropas largas y roçagantes ya tan cortas y tan deshonestas que aun no cubren las uerguenças, ya pellotes y aljubillas, ya sayos y sayuelas con muchos pliegues a las caderas, contra la composiçion de los varones que, como pareçerá adelante, han de tener y tienen naturalmente grandes arcas y pechos, y la caderas pequeñas al contrario de las hembras, pues en el ceñir ya cintas apretadas y broñidas y angostas ya floxas, anchas de caderas, ya cintos llanos ya moriscos, y de mill -62v- maneras y muy costosamente labrados. Ya copagorjas en las cintas, ya dagas ya puñales. Ya bolsas de seda o de lana muy labradas. Ya tassas carnieles escarcelas o almacracas.

En las cabeças quando caperuças y carmeñolas de vara en luengo, quando capellos con grand beca y grand ruedo, ya con pequeño; quando sombreros ya pelados y pardillos, ya negros y de fieltro, ya con grand ruedo, ya con pequeño; quando bonetes doblados quando senzillos, quando leuantados y llenos de viento, que pequeño ayre los derriba y da con ellos en el suelo; quando metidos y encaxquetados que han menester ayuda para quitarlos; quando sanos, quando hendidos, morados, bermejos, verdes, azules, pardillos y negros, alharemes y sudarios ençima dellos. Quando cabellos muy alto cerçenados y hazia -63r-arriba alçados y encrespados, quando luengos muy peynados y aleznados, y con grand compás y grand estudio hechos y afeytados; lo primero era natural y masculino, lo segundo mugeril y femenino, y por esso defendido segund que ya arriba fue apuntado.

En el calçado las calças vn tiempo abiertas y otro cerradas; en vn tiempo vizcaynas y en otro italianas; vn tiempo botas francesas, delgadas y muy estrechas, otro tiempo anchas, gruessas y atacadas; otro tiempo borzeguies de mill colores con vandas o syn vandas, ya muy anchos, ya muy es- 
trechos y apretados. En los pies quando calças de soleta con chinelas o sin ellas, quando çapatos de cuerda con puntas mucho luengas, con galochas o sin ellas; quando çapatos romos con alcorques o sin ellos, ya blancos y de uenado, ya de diuersos colores con puertas o syn puertas, con -63v-cayreles de aro 212 o de seda labrados, ya de muchos lazos ya de vn lazo, ya abiertos ya cerrados. O miseria de gente seglar/.

$>$ Mas< (fol. 181r) quién podrá contar ni /medio/ dezir el estudio demasiado que >se < tiene y ha tenido en vestir e traer e calçar, e los pe/c/cados de muchas maneras: de soberuia, de vanidad, de luxuria e dissolucion, de prodigalidad e ambicion, de rapinas e tiempos perdidos que se cometen en lo tal.

Nerdad es que si desque el mundo es mundo y ouo locos en él que toda su felicidad pusiessen en el traer, ouo algund siglo o tiempo honesto en que los varones se midies/s/en y reduxiessen a lo simple y natural, cessando de lo compuesto, fengido y mucho suplerfluo, ha seido este nuestro en que por la bondad de Nuestro Señor, de veynte años acá, en todo lo su sodicho hay mucha honestad y modestia. Mereció las gracias desto el rey don Enrique -64r- quarto, que en esto fue ordenado, muy cuerdo y muy honesto, el qual, honestando su real persona y siguiendo en esto lo natural y uerdadero, hizo honestar a todo el reyno. Quanto a los varones, digo mayores y menores, y caualleros y escuderos, casados y mancebos, que quanto a las dueñas grandes y pequeñas mucho y más que mucho cresció la dissolucion en su tiempo/. > Mucho e más que mucho deuria mirar en esto el príncipe, rey e reyna de qualquier reyno, porque< es regla general ${ }^{213}$ que no puede faltar que, qual el rey e qual la reyna, en lo malo y en lo bueno 214 , tal es todo el reyno, /en lo varonil y en lo mugeriego/, >assi en esto como en todo lo al<. Por lo qual en Grecia al rey llaman basileo, que quiere dezir pilar del pueblo, porque si el >rey< está derecho, ordenado e honesto tal está todo el pueblo $>$ que carga sobre él, e si el rey declina y se acuesta a qualquier vicio grande o pequeño tanbien se acuesta e declina tras él el pueblo< ${ }^{215}$. Esto, >segunt dize Sant Ysidoro<, significa la corona real que el rey trae en la cabeça, que sostiene los pueblos y está cercado e cargado dellos, e que doquier que se mueue $>n<e$ va $>n$ el rey e la reyna $<$ en las costumbres $>$ honestas $<e^{216}$ deshonestas allá 217 van y se mu(fol. 181v)euen -64v- ellos. Cosa es mucho de mirar e avn mucho de llorar a los príncipes que no son buenos, porque dissoluiendose ellos escandalizan y prouocan a dissolucion $>a$ los de< sus reynos, y $\mathrm{pe} / \mathrm{c} / \mathrm{can}$ grauissimamente dando occasion a que pequen ellos, y as $<\mathrm{s}>\mathrm{i}$

\footnotetext{
212 Ms, 63v: lectura dudosa.

213 Ms, 64r: regla es general.

$214 \mathrm{Ms}, 64 \mathrm{r}$ : en lo bueno y en lo malo.

215 En el Ms, $64 \mathrm{r}$ se suprime esta última frase y dice: todo el pueblo, etc.

$216 \mathrm{Ms}, 64 \mathrm{r}$ : 0 .

$217 \mathrm{Ms}, 64 \mathrm{r}$ : en las costumbres o deshonestas alli.
} 
serán atormentados más que todos en los ynfiernos. Y por el contrario, los buenos príncipes con todos y sobre todos enxalçados en los cielos, quales quiera Nuestro Señor que siempre sean los nuestros. >Amén<.

\section{[104] /Capitulo quinto. Pone praticas como en la manera susodi- cha han excedido y exceden las mugeres/.}

E como quier que en lo susodicho exceden y pecan los ombres, pero mucho mas exceden y pecan las mugeres en la manera de su traher ${ }^{218}$, tocar, vestir, y calçar, y en todo el atauio de sus personas, y avn aosadas en lo de sus camas, palacios y estrados, /sino que no es aqui lugar para demostrar que tanbien en aquello hay muchos peccados. -65r. Cosa uergonçosa y mucho curiosa parece a nos hablar esto/. Digalo el profeta Ysayas ${ }^{219}$, que lo tracta y reprehende todo /por menudo/, de pies /fast/a cabeça, y diganlo los otros profetas y los San/c/tos Apostoles, que lo reprehenden grauemente, que si de todo ello ouiesse yo a que dezir por menudo nunca acabaria ${ }^{220}$. Mas remuérdenos la consçientia porque el excesso es tan grande en algo de lo deste tiempo, que si callassemos/nos/ hablarian las piedras, como dize el Sancto Euangelio.

Agora pues, demandando perdon a las honestas y cargando la culpa a la dissolution de las otras, començemos de las cabeças. Casadas y por casar se dissueluen primeramente en criar y açufrar los cabellos, començando a representar el çufre de los infiernos y las biuas llamas de aquel terrible fuego humoso, obscuro y negro en que han de arder con ellos; -65v- ya descubren toda la cabeça por que parezcan más los cabellos; ya la cubren con crespina de oro o con aluanegas de seda muy sotilmente texidas y obradas, o con filetes leuantados, o solamente llanas; ya echan la trencha de fuera y hazen grand partidura, torciendo los cabellos y componiendolos fasta cobrir las orejas, y aun dexando algunas mechuelas fuera, ya hazen dellos diadema; ya los cogen entrançados costosos y muy delgados con cintas de oro o de seda liados; ya se tocan cubriendo la cabeça toda y atrás partiduras y descubriendo la media; otras algunas, que piensan tener el medio, descubren sola la trencha. Las tocas pocas vezes son luengas que desciendan fasta los pechos, muchas vezes son cortas que apenas cubren las orejas; ya son cambrais de lino, ya son de seda, ya son implas romanas, ya encrespadas ya espumillas, ya lenca-66r-rejas ya llanas, ya sanas ya crepadas; ya las ponen con bueltas ya

$218 \mathrm{Ms}, 64 \mathrm{v}$ : Vengamos al estudio demasiado y al excesso muy praticado que comunmente tienen las dueñas en su traher.

219 Ms, 65r: Mas el propheta Ysayas nos quita la uerguença.

$220 \mathrm{Ms}, 65 \mathrm{r}$ : pues çierto es assi que yo hablo y escriuo dello de mala gana. 
las hazen tambas, syn moños o con moños, nunca fallecen de moños que ayuden a leuantarlas y, lo que es peor y más defendido, que algunas ponen bonetes sin uerguença en sus caras. Callo de los firmulles y joyeles de las frentes, de los cercillos y arracadas de los collares, sartales y almanacas. Vengo a las alcandoras, la bradas y cintadas, y de muchas maneras plegadas, a los corpetes de oro broslados o de mucha seda labrados que ponen ante los pechos abique eo quod inter secus latet. Solian usar gorgueras que cubrian las espaldas y los pechos como arriba se tocaua, aunque eran tan delgadas, labradas y randadas que se podia bien trasluzir la blancura dellos, pero más honesto era que traerlos descubiertos. $Y$ a quien podrá dezir las mu-66v-danças de las faldetas y diuersidades de muchas; y muchas maneras de los briales 221 de fustán, de paño, de seda y, a las vezes, de brocado; de las cortapisas; de las alhorzas, ya chamorras ya francesas; de las faldas, quando muy luegas quando muy cortas, y aun quando redondas, y aquello era bueno; de las aliubas, cotas, balandranes, marlotas y tauardos de paño, de peña, de lino y de seda; de las cintas y texillos de diuersas maneras labrados y guarneçidos; y de los redondeles y por demases y mantos con gonelas del otro tiempo; y de los mantos lombardos y seuillanos, quando cintados quando cayrelados. Si todo se ouies/s/e de dezir nunca acabariamos. $Y$ de los chapines, de diuersas mareras obrados y labrados, castellanos y valencianos, y tan altos y de tan grand quantidad que aperias hay ya corchos que lo puedan bastar, a grand -67r-costa del paño, porque tanto ha de crescer su uestidura quanto el chapin finge de altura, aunque ha de faltar algo y no llegar al suelo para que parezca lo pintado del chapin o del çueco. Pues aun - añaden Ezechiel propheta e Ysayas- de las manillas de los braços y de los anillos de los dedos, y otras muchas cosas dizen ellos y los otros que yo canso de poner.

[105] Basta y deue bastar que sepan las que exceden en esta manera, y los padres o maridos que lo consyenten, que ellos (fol. 182r) y ellas offenden mortal o venialmente, qui a facientes e consentientes. Este excesso defiende el Sancto Euangelio quando nos >a<conseja y manda que no seamos mucho solicitos de la vestidura $n i>n<$ del mantenimiento. El cuydado demasiado defiende 222 de las cosas semejantes mas no $>n<$ el de lo necessario, a cada vno segund su estado.

[106] Uerdad es que el sabio Salomon alaba a la muger virtuosa de ha-67v-zendosa $y>d e<$ aliñosa, $y$ de auer hecho para sy vestidura preciosa de diuersos colores, y de tener proueydos a los de su casa de vestiduras dobladas. Mas aquellos loores /más/ son de virtudes $y>d e<$ bondades significadas y dadas a entender so ${ }^{223}$ aquellas semejanças de vestiduras /que

221 Repetido: de los briales.

222 Ms, 67r: el cuydado defiende demasiado.

223 Ms, 67: por. 
no de terrenales composturas 224/. E avn el rey Salomon fue de los que mucho excedieron /en el comer y/ en el vestir y /en el/ tra>h<er en su persona $y$ en sus mugeres, $y$ en los familiares y seruidores, tanto que la reyna de Sabba se marauilló de las vestiduras de los ministros quando vino a le oyr y conoscer. $Y$ as/s/y haze la Sancta Escriptura comparación a las vestiduras de Salomon quando de excellentes vestidu(fol. 182v)ras dize algo. $Y$ avn Nuestro Redemptor -68r- dellas hizo mencion como escarnesciendo e burlando quando dixo que nunca Salomon en todo su triunplo (sic) e gloria /como la/ alcançó > vestidura tan hermosá como la del lilio e de la rosa 225 .

[107] Tanbien es verdad que la reyna Hester vestiduras tenia preciosas, luengas e muy ${ }^{226}$ costosas, e que vna donzella le >kleuaua las faldas, mas ella mesma confiessa que nunca se deleytó en vestirlas ni vsó dellas sino 227 quando auia de parecer antel rey, por complir con el estado real e con él. >Éstas que assi se visten y se precian del traher dize el santo propheta e rey Dauid que son semejantes a los ydolos e ymágines de los templos<.

[108] De Nuestro Redemptor dizen algunos que traya manto azul e la saya de encima morada, mas del /uestir de Nuestro Señor/ e de Nuestra Señora no /h/ay scripta cosa cierta >cerca desto<, e lo que más se cree >es< que él e Nuestra Señora andouiessen vestidos de gruesso $>e$ pobre $<$ buriel. $E>$ bien se sufre $<$ que trax/i/esse dos o tres sayas e manto encima por se conformar al vso de los sacerdotes e honestos judios -68v- de aquel tiempo, e por consolar con su ex(fol. 183r)emplo a los flacos que no $>n<$ pueden passar con vna vestidura, especialmente en las tierras frias, pintanlos con vestiduras de color e que parecen preciosas por adornar la pintura, /como pintan a Nuestra Señora uestida de brocada, y ella nunca lo uestió ni aun fino paño/.

[109] Capitulo XVI 228. De la quarta manera de exceder y pe/c/car en comer $y>e n<$ beuer, $y$ en vestir y en calçar, que es no guardando la conueniencia del tiempo.

[110] La quarta manera de exceder en el comer e beuer es no guardando la conueniencia del tiempo. $>Y$ esto en dos maneras<: 0 anticipando mucho la hora $\sin$ causa e sin necessidad, lo qual reprehende la Sancta Escriptura di-

224 Ms, 68r: $Y$ continúa: "éstas que assi se visten y se precian del traer dize el sancto propheta y rey Dauid que son semejantes a los idolos e imagenes de los templos", que no copiamos pues en la edición viene al final del párrafo siguiente.

$225 \mathrm{Ms}, 68 \mathrm{r}$ : nunca Salomon alcançara uestidura tan linda y tan bien colorada en todo su triumpho y gloria como la alcança el lilio y la rosa.

$22.6 \mathrm{Ms}, 68 \mathrm{r}$ : mucho.

$227 \mathrm{Ms}, 68 \mathrm{r}$ : saluo.

228 Ms, 68v: sexto. 
ziendo que la tierra es desuenturada, que tiene rey moço e príncipes que comen de mañana, o comiendo en los dias de abstinencia alguna vianda vedada. E assi -69r-conte>s<ce exceder en el vestir e tra/h/er, no guardando lo que conuiene al tiempo, ca mucho yerra y excede el que en tiempo de lloro e de tribulacion viste vestiduras de alegria, e por el contrario el que en tiempo de alegria y de so//lem $>p<n i$ (fol. 183v)dad tra $>h<e$ vestiduras de tristeza y $c / u /$ otidianas.

[111] Desto y esso es reprehendido ${ }^{229}$ en el Sancto Euangelio, /hablando por semejança/, el que entró a comer en ${ }^{230}$ las bodas $\sin >|<|$ euar vestidura de boda; $>\mathrm{y}<\mathrm{a} / \mathrm{s} / \mathrm{sy}$ reprehendió el condestable Joab a su buen rey Dauid porque no vestia vestidura $s o l / / / e>m<n e$ y de alegria quando le dio Nuestro Señor victoria de su mal hijo Absalon y ge la hizo vestir.

[112] E los profetas amonestauan 231 al pueblo de Ysrael que vestiesse vestiduras tristes para hazer penitencia, e >que </en otro/tiempo de perdon y de consolacion desnudassen aquéllas y vestiessen vestiduras de plazer -69v- y de fiesta. En esta manera yerran comunmente los nobles y hidalgos, caualleros y escuderos, grandes y pequeños, que podiendolo 232 bien hazer $y$ teniendo mudas de vestiduras $>a<$ mejores y no tan buenas no hazen di/f/ferencia del Carnal a la Quaresma, ni del viernes al domingo, ni del cutiano (sic) a la fiesta; antes piensan que guardar esta diferencia ${ }^{233}$ pertenece a los aldeanos $/ y />a$ los $<$ o/f/ficiales $y>a$ los $<$ villanos, y por esso ellos por el contrario visten lo mejor entre semana, y el domingo o 234 la Pascua no salen mejo(fol. 184r)rados.

[113] El contrario da Nuestro Señor a entender hablando por el profeta Ezechiel, >ya< mandando que la puerta del templo por do el príncipe auia de entrar no se abriesse syno el sab/b/ado, saluo si entre semana quisie/s/se el príncipe venir a o/f/frecer algun/d/ sacrificio voluntario y extraordinario.

[114] Las dueñas comunmente se ordenan major (sic) en esto, que grandes y pequeñas -70 r- salen $/ \tan /$ vestidas $>y</ \tan /$ reluzientes, pintadas e conpuestas en las fiestas por que esperan ser más vistas en los tales dias /que la mitad bastaria/. E algunas 235 y avn muchas exceden en no guardar la templa/n/ça y mesura deuida al tiempo de la penitencia y al lugar de la tristeza. Ca ${ }^{236}$ assy se afeytan y visten en Quaresma como en Carnal, e assy van a las exequias de los defunctos sy non son $>$ sus $<$ pa-

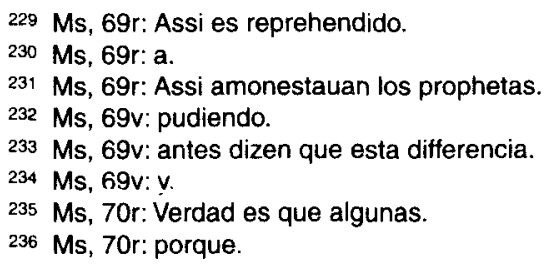


rientes, como si fuessen a bodas o a bateos, todo >esto< porque alli concurren gentes que las han de ver e mirar /y ellas no quieren a nadie parecer mal/. Reprehende esto ${ }^{237}$ Nuestro Señor /hablando por semejança/ en el San/c/to Euangelio /de los moçuelos que se dizen vnos a otros en los juegos que hazen entre sy/ >diziendo<: cantamos e no respondistes, reymos e no reystes, lloramos e no llorastes. Y esto mesmo el San/c/to Apostol, que quiere que lloremos con los que lloren e nos gozemos -70v- con los que se gozan (fol. 184v).

[115] Capitulo XVII ${ }^{238}$. De la quinta manera de peccar en lo susodicho, que es comiendo o vistiendo con grand $>e<$ ardor y deleyte, e haziendo nueuas inuenciones e trajes.

[116] >La< quinta e postrimera manera de exceder en el comer y beuer es quando se toma la vianda con mucho ardor y deleyte, avnque no sea en mucha quantidad ni preciosa, ni con mucha diligencia guisada ni fuera de tiempo tomada. Personas ay muchas que con mayor sed y dele/i/tacion beuen el agua que otras personas el vino. Este ardor y deleyte parece en la pri/e/ssa con que >las tales personas < toman ${ }^{239}$ el mantenimiento, las quales ponen entonçes alli todo 240 su sentido e intento, /que parece/ que lentonces/ ni oyen ni veen, desalados sobre lo que comen: lassi/ como el açor sobre la perdiz, o el milano sobre $>\mathrm{e}<\mathrm{l}$ pollo, que con mucha hambre ha $>n<$ caçado; ni espera/ua/ $>n$ a $<-71$ r- biendezir primero la mesa, ni curan de reuanar el pan, ni esperan a que los 241 trayan la vianda $y>$ que < ge la corten /cozida o assada/, mas en llegando a la mesa luego, sin detener/se/ vn punto, muerden en el pan y dan grandes bocados en él, $y$ hinchen ambos carrillos y lo (fol. 185r) tragan syn mascar como sy nunca se esperassen hartar.

[117] En esta manera pe/c/can los que >todo< su >e<studio /e pensamiento/ parece que ponen >en< como satiffarán al vientre, a lo menos en aquel tiempo. $>\mathrm{Y}<\mathrm{a} / \mathrm{s} / \mathrm{sy}$ pe/c/có Esau, que tuuo en más aquella escudilla de lantejas >que le dio Jacob, su hermano<, que la dignidad de ser primogenito - que entonces era gran/d/cosa y avn agora $>$ lo es a< donde /h/ay mayoradgo - > no es auida por pequeña<, y assy le culpa dello el San/c/to Apostol.

\footnotetext{
237 Ms, 70r: Esto reprueua.

238 Ms, 70v: septimo.

$239 \mathrm{Ms}, 70 \mathrm{v}$ : con que se toma.

$240 \mathrm{Ms}, 70 \mathrm{v}$ : $y$ en poner alli el ombre todo.

$241 \mathrm{Ms}, 71 \mathrm{r}$ : les.
} 
[118] En esta manera pe/c/caron muchos de los que con el buen juez /y buen duque o caudillo y capitan/ Gedeon eran ayuntados en la hueste de Israel, que se echaron de buças a beuer por satiffazer más ayna -71v-e más complidamente a su sed; no lo hizieron a/s/si los trezientos que quedaron, los quales, inclinados algun/d/ poco, tomaron la ${ }^{242}$ agua poco a poco con la mano. Con >e<ste ardor e deleyte deuieran comer en Egipto los puerros e >las< cebollas, e los cogombros y pepinos, e las carnes de poco precio muchos de los judios, pues que tanta cobdicia y desseo tenian de todo ello 243 andando por el desierto. Con este ardor y de/s/seo deuieran comer las codornizes que alli les dio Nuestro Señor, e por esso >dize la Santa Escriptura:< se hartaron hasta salirles por las narizes. Uerdad es (fol. 185v) que Nuestro Señor les mandó comer apriessa el cordero pascual, pero aquello era para significar >la gran caridad e amor con que se ha de recebir la sancta comunion, e con que se ha de remembrar la sagrada passion de Jesuchristo, figurado por aquel cordero. $E$ tanbien ge lo mandó comer asi aprissa por les dar a entender que estauan de camino, ca aquella noche auian de salir y salieron< de Egypto ${ }^{244}$. A estos tales llama el sabio eclesiastico ombres infrunitos, que quiere dezir >desenfrenados e $<$ muy golosos.

[119] Agora pues, viniendo a nuestro proposito, en esta manera $-72 \mathrm{r}$ acae $>s<c e$ exceder y excediendo pe/c/car en el vestir e traher, ca son algunas personas que todo su deleyte e consolacion pare $>c e<$ que ponen $e$ tienen en <aqu>ello. Estas son las personas que no se visten e tra/h/en por se conformar al vso comun de aquellas tierras en que biuen e conuersan, /ni por satisfazer a su condicion y estado/, ni por aplazer los casados a sus mugeres, ni las dueñas por aplazer a sus maridos, mas 245 /tanbien y mejor/ visten e atauian sse < porque les deleyta parecer bien a quien quiera len aquella manera/, e si no a otri (sic) syquiera a sy mesmos e a sy mesmas. Estas son /las/ personas que se precian de inuentar trajes nueuos de diuersas maneras, porque como todo su (fol. 186r) deleyte sea ${ }^{246}$ en se vestir e tra $>h<e r, e>c o m o<$ las cosas tenporales tengan 247 esta condi-72v-cion: que luego que son auidas e vsadas dan hastío e son menospreciadas ${ }^{248}$, es forçado que busquen otras nueuas que por su nouedad les $>$ a $<$ plegan. Las quales inuenciones son a gran/d/ peligro e cargo de sus con/s/ciencias, porque no solamente pierden assi ( $\mathrm{sic}$ ) mesmas las tales personas

242 Ms, 71r: el.

$243 \mathrm{Ms}, 71 \mathrm{r}$ : de tornar a ello.

$244 \mathrm{Ms}, 71 \mathrm{v}$ : para significar la festinancia y priessa con que fueron compellidos a botar de Egipto.

$245 \mathrm{Ms}, 72$ r: ca.

246 Ms, 72 r: es.

$247 \mathrm{Ms}, 72 \mathrm{r}$ : tienen.

$248 \mathrm{Ms}, 72 \mathrm{v}$ : menos queridas y amadas. 
que los $>$ tales $<$ trajes /nueuos/ assi liuiana e vanagloriosamente inuentan, más pierden e son causa que se pierdan otras $>$ muchas $<$ liuianas personas, que son muy prestas para les remedar en aquella vanagloria e liuiandad. $Y$ éstas son muy muchas 249 tanbien en los varones como en las mugeres, porque comunmente, desde nuestra mocedad e >avn< desde nuestra niñez e comienço del mundo, como dize la San/c/ta Scriptura, somos prestos para el mal.

[120] El san/c/to Moyse/n/, e los psalmos e todos los profetas, amenazan mucho a >todas < las personas que hazen -73r- tales inuenciones, y denuncian que executará Nuestro Señor en ellas la $>S<$ vengança de su ira. Aquel rico malauenturado de que fabla el Sancto Euangelio y que fue arriba allegado, >puesto en el infierno< temia mucho que ${ }^{250}$ sus cinco hermanos que auia dexado biuos no descendiessen a ser >alli con él< penados 251; (fol. 186v) e procuraua que el patriarcha Abra/h/am les enbiasse alguno de los que estauan en el limbo para que les denunciasse el tormento e fuego infernal en que >él< estaua ardiendo, por que hiziessen penitencia y miereciessen emendandose escapar de aquella perdurable e grauissima pena. E /esto/ no lo hazia él por $>l a<$ caridad e amor que a sus hermanos touiesse, ca los dañados ninguna caridad tienen ni otra alguna virtud ${ }^{252}$ para que desseen que algunos sean saluos, antes querrian que todos fuessen - $73 \mathrm{v}$ - $/ \mathrm{y} / \mathrm{como}$ ellos e con ellos condepnados ${ }^{253}$, como quier que avn puede tanto en ellos la inclinacion e amor natural, que pues saben que algunos han de ser saluos querrian que lo fuessen sus debdas mas que no los estraños ${ }^{254}$. Pues no /sólo/ procuraua >aquello < por caridad mas procuraualo principalmente porque no le fuesse a él mesmo acre/s/centada la pena e tormento si ellos viniessen e descendiessen en aquel fuego infernal, ca él, como hermano mayor e quasi 255 regidor dellos $>e<$ principal les auia dado muy mal exemplo, e por consiguiente los auia mucho escandalizado e prouocado a pe/c/car comiendo e vestiendo demasiado. (fol. 187r) /E assi acaba la tercera parte de cinco maneras en que acaeçe peccar y exceder en el uestir y traher, como son çinco las maneras principales en que acaeçe peccar en el comer y en el beuer/.

$249^{\circ} \mathrm{Ms}, 72 \mathrm{v}$ : son las mas de las personas.

$250 \mathrm{Ms}, 73 \mathrm{r}$ : rehusaria mucho que.

251 Ms, 73r: penados con él en los infiernos.

252 Ms, 73r; otra uirtud alguna.

$253 \mathrm{Ms}, 73 \mathrm{r} / \mathrm{v}$ : fuesen con ellos y como ellos.

$254 \mathrm{Ms}, 73 \mathrm{v}$ : y como ellos dañados, aunque diz que no está en ellos tan corrompida ni tan del todo perdida la inclinaçion y amor natural que no quieran, que pues algunos han de ser saluos, que lo sean ante sus debdos que no los estraños.

255 Ms, $73 v$ : como. 
[121] /La quarta -74r- parte demuestra que el hábito susodicho, deshonesto y peregrino, de las caderas y uerdugos se deuió y pudo muy bien uedar en la manera que fue uedado/.

Capitulo XVIII 256. Demuestra que los prelados e /cor/regidores de las comunidades pueden e deuen ordenar e poner ley e leyes /a/cerca de los trajes.

[122] Agora es de saber que los prelados e regidores de los pueblos e comunidades, /assi/ eclesiasticos e ${ }^{257}$ seglares, pueden e deuen ordenar e poner ley e leyes cerca de los trajes y avn cerca de los comeres; avnque no era tanto de nuestro proposito dezir de los excessos del comer y >del< beuer mas como parece de lo susodicho, de lo vno e de lo otro, es quasi vna sentencia e vn mesmo juyzio.

[123] Es cierto que el of/f/icio de los prelados e gouernadores eclesiasticos e seglares es procurar con toda diligencia y estudio que los cibdadanos $-74 \mathrm{v}$ - a ellos subjectos sean justos, virtuosos e buenos, e no -como piensan algunos - que su o/f/ficio sea procurar que la cibdad o comunidad sea abastada de los bienes temporales. Ca grand yerro es e grand desordenacion a qualquiera poner su fin $y>e<$ studio en alcançar (fol. 187v) abundancia de bienes temporales, que son riquezas, hon $>r<$ ras y deleytes carnales; porque éstos son muy pequeños bienes e tan pequeños que grandes sabios touieron que ni son ni deuen ser nombrados bienes porque vieron y veemos claramente que los tienen >y posseen< muchos ombres malos, y que no hazen al ombre bueno, antes son >comunmente< causa y o/c/casyon de muchos males y pe/c/cados.

[124] Y por esso Nuestro Redemptor llamó a las riquezas mamona iniquitatis y al comienço de su sancta ley euangelica los detestó y denostó 258 diziendo: guay de vos, ricos y abastados, que teneys agora vuestra consolacion -75r- y estais hartos, que despues padecereis tribulacion, hambre y mengua; guay de los que agora reys y andais en deleytes, que despues llorareys; >guay de los que agora soys bendezidos e honrrados, que despues sereys < maldezidos ${ }^{259}$ y denostados. $Y$, por el contrario, bienauenturados los pobres de voluntad, esto es, los que de grado e con ygual coraçon toman y sufren la pobreza, /que/ despues seran ricos y abastados; $y$ bienauenturados los que (fol. 188r) agora lloran haziendo penitencia, que despues reyrán y seran consolados; y bienauenturados los

256 Ms, 74r: Primero.

257 Ms, 74r: como.

258 Ms, 74v: Las denostó y detestó.

259 Ms, 75r: maldichos. 
que agora son maldezidos 260 y denostados sin causa y sin razon, que despues seran bendezidos y honr $>$ r<ados. Pues, a/s/sy como estas cosas temporales, -/sean o no sean bienes o males/ - no hazen al ombre bueno nin bienauenturado 261, por ser como lo son /a la uerdad/ cosas baxas y despreciadas avnque de muchos muy tenidos, queridos y extimados, assi no hazen buena 262 ni bienauenturada $>$ toda $<-75 \mathrm{v}$ la cibdad o comunidad, porque como se han con la parte que es cada cibdadano, assy se han con él todo que es la cibdad. Ni avn es el fin y bien principal de la cibdad o comunidad que tenga paz, que es el mayor de los bienes temporales y el que más parece que los gouernadores deuien procurar y el que grandes sabios dixeron, segund parece prima facie que era y es todo el bien de la cibdad /el qual bien se llama republica o bien público y comun. Mas aun ni es esta la uerdad/, saluo sy fablas/s/en y fablassemos de la paz de buena voluntad que an/n/unciaron los sanctos angeles en la Natiuidad de Nuestro Saluador, ca esta vino 263 él a dar, y por esso fue llamado príncipe de paz. Y ésta es la que >él< mucho enco(fol. 188v)mendó e dexó a sus >sanctos< discipulos, e a nos con ellos por herencia principal, diziendo quando deste mundo queria passar: mi paz vos do e -76r- paz vos dexo; no la que $>e<$ mundo tiene e da, mas paz quiso dezir de buena voluntad. Porque la paz temporal, avnque se pudiesse auer en la cibdad entre todos los cibdadanos por manera que ninguno turbasse a otro, ni se hiziessen injurias $n i>n<$ daños por miedo de $>$ no $<$ ser justiciados ni penados, $n i>n<$ avn por esso no serian los cibdadanos buenos ${ }^{264}$ ca podrian oc/c/ultamente y en sí mesmos cometer muchos pe/c/cados, como cada dia se cometen e no son sabidos, o avnque lo sean no son castigados.

[125] Pues la verdad es la que deximos: que el o/f/ficio principal /y studio/ de los rectores e prelados es y ha de ser procurar con toda diligencia que sean justos, /y/ virtuosos e buenos los subditos e cibdadanos, para lo qual es primeramente necessario que se quiten las causas e o/c/casiones de los pec/c/ados. $>E$, como parezca de lo susodicho que en los trajes $y$ en los comeres demasiados pueda auer e aya comunmente (fol. 189r) muchos e grandes pecados<, síguese que -76v-pueden y deuen ordenar $>e$ poner< cerca dello ley y leyes para que sean euitados. Las quales tienen dos e/f/fectos: alumbrar y auisar alos buenos, y temprar ${ }^{265}$ y refrenar a los malos con las penas ciuiles o criminales que en los traspassadores dellas se /h/an de executar.

\footnotetext{
260 Ms, 75r: maldichos.

261 Ms, 75r: bienauenturado ni bueno.

$262 \mathrm{Ms}, 75 \mathrm{r}$ : tenidas, queridas y estimadas, assi no hazen bien.

$263 \mathrm{Ms}, 75 \mathrm{v}$ : porque aquesta y no otra vino.

$264 \mathrm{Ms}, 76 \mathrm{r}$ : no serian buenos los çibdadanos.

$265 \mathrm{Ms}, 76 \mathrm{v}$ : reprimir.
} 
[126] Capitulo XIX ${ }^{266}$. Demuestra que Dios, Nuestro Señor, quando regía al pueblo de Ysra>h<el por sí mesmo, atnes (sic) que le die/s/se rey, y despues esse mismo Dios humanado en la persona del hijo e los Sanctos Apostoles, e despues los San/c/tos Doctores antiguos e modernos pusieron ley e leyes /a/cerca de los trajes ${ }^{267}$.

[127] $>E<$ assy hallamos que Nuestro Señor dio leyes cerca del vestir e traher a/l/ su pueblo de Israel. Ca les mandó que no vistiessen vestidura texida de lino con lana 268 , no porque ella en sí era mala mas porque los ydolatras, a honrra de sus dioses, se -77r-vestian en aquella manera. E mandó que el varon no vistiesse vestidura de muger ni la muger vistie/s/se (fol. 189v) vestidura de varon, assi por aquella mesma razon como por euitar la cobdicia carnal y apetito de pe/c/car que en aquella manera se podia despertar y acrescentar. $Y$ mandó que todos traxiessen cierta manera de hábito en el qual fuessen conoscidos por judios, conuiene saber: quatro fimbrias en quatro partes de los mantos, y trenças o cordones azules puestos en ellas, $e$ assi de otras menudencias. $Y$, porque le desplazía que los egipcianos touiessen vestiduras preciosas e sobradas, mandó que los despojassen dellas los hijos de Ysrael que las auian necessarias. E porque las mugeres de su pueblo excedian de la honestad que deuian guardar en su tocar, y en su vestir e calçar, las reprehendia ${ }^{269}$ de todo ello, assi por me-77v-nudo y asperamente, por muchos de los prophetas, e por Ysayas especialmente ${ }^{270}$, >como arriba fue tocado<.

[128] Esto mesmo hizo cerca del comer, ca mandó ayunar ciertos dias y vedó ciertas viandas. $E$, avn trayendolos por el desierto e dandoles aquel manjar del cielo, qui(fol. 190r)so que todos tomassen >cada dia< cierta e ygual quantia, y que tomassen los viernes para los sa/b/bados, y que los que andauan buscando en ello diuersos e demasiados sabores y deleytes, e por esso coziendolo 271 y assandolo, fue/s/sen desconsolados.

[129] Item, Nuestro Redemptor e maestro Ihesuchristo por sí mesmo dio ley, avnque mucho general, assi >en esto $<$ como en todo lo al, de la manera >que< sus fieles se deuian auer en el vestir y en el comer, diziendo que no seamos sol>l<icitos e mucho cuydosos qué comeremos o qué vestiremos. $E$ >diola < alabando en Sant Juan la aspereza e simpleza ${ }^{272}$ de las vestiduras $y$ de las viandas, $>y<$ reprehendiendo la curio-78r-sidad y

\footnotetext{
266 Ms, 76v: segundo.

$267 \mathrm{Ms}, 76 \mathrm{v}$ : traheres

268 Ms, 76v: con lino de lana.

269 Ms, 77r: reprehende.

$270 \mathrm{Ms}, 77 \mathrm{v}$ : y espeçialmente por Ysayas.

271 Ms, 77v: y coziendolo por ello.

272 Ms, 77v: Iohan la simpleza y aspereza.
} 
apparato dellas en aquel rico malauenturado de que muchas vezes auemos hablado.

[130] Item, los San/c/tos Apostoles entendien 273 en la >no < manera del vestir y del tra> $h<e r$, especialmente Sant Pedro y Sant Pablo, principales entre todos. Los quales reprehenden y reprueuan las trenchas, /y/ partiduras e /las/ cabelleras en las mugeres ${ }^{274}$, y las vestiduras precio(tol. 190v)sas $>y<$ de oro $0>$ de $<$ seda, e las perlas e 275 piedras preciosas, dando ley e regla que deue ser el hábito de la muger moderado e honesto 276 .

[131] $Y$ despues de los Apostoles los San/c/tos Do/c/tores, más abiertamente e más por menudo, han hablado de/aque/sto 277 y mucho reprehendido lo demasiado e superfluo. $\mathrm{E}$ han determinado que, como dixo Platon, philosopho, muchas de las artes que entienden en el vestir e calçar deurian ser desterradas de la -78v- cibdad, y >que de $<$ las que quedassen como más necessarias se deuria/n/ algo e avn mucho cercenar. Porque tanbien $\mathrm{pe} / \mathrm{c} / \mathrm{can}$ los of/f/iciales que inuentan e hazen los trajes liuianos y deshonestos como las personas que vsan dellos. $Y$ pone Sant Crisostomo exenplo en la /chapineria o çapateria -que es/ arte de hazer chapines, çuecos e /otros/ qualesquier calçados-, la qual arte dize, e dize verdad, que dexado lo neces $>$ s<ario ha inuentado, e de cada dia inuenta e haze, calçado superfluo e de mucha vanidad.

[132] Avn los San/c/tos Do/c/tores modernos, y especialmente San/c/to Thomas de Aquino, >que es más piadoso que otro<, dizen que es o 278 deue ser defendido el hábito o tra(fol. 191r)je superfluo, desuergonçado e 279 impúdico, e habla especialmente de los vestires e trajes, $y>$ de $<$ qualesquier composturas e atauios de las mugeres casadas e por casar.

\section{[133] Capitulo XX ${ }^{280}$. Que los prelados -79 - eclesiasticos pudie-} ron e avn deuieron vedar so pena de excom/ $\mathrm{m} /$ union que aquel hábito deshonesto non se vsasse más.

[134] De todo lo susodicho se sigue que los prelados e/c/clesiasticos pueden defender e mandar, so pena de exco/m/munion, que los onbres ni las mugeres no trayan ciertos hábitos e trajes. Ca puede el prelado e/c/cle-

273 Ms, 78r: entendieron.

$274 \mathrm{Ms}, 78 \mathrm{r}$ : en las dueñas.

275 Ms, 78r: 0 .

$276 \mathrm{Ms}, 78 \mathrm{r}$ : y regla que el habito de la dueña deue ser temprado y uergonçoso.

$277 \mathrm{Ms}, 78 \mathrm{r}$ : de aquesto.

278 Ms, 78v: $y$.

$279 \mathrm{Ms}, 78 \mathrm{v}: 0$.

280 Ms, 78v: tercero. 
siastico, si viere que es necessario defender, so pena de excom $/ \mathrm{m} /$ union, /que no se cometa/ qualquier pec/c/ado mortal e avn compeller, so ${ }^{281}$ essa mesma pena, a que salga y desista del peccado mortal/cometido/ la persona que en el /peccado/ perseuera. No obstante que la exco/m/munion 282 sea la mayor de las penas que en esta presente vida se pueden dar, porque aparta al pe/c/cador de la comuni>caci<on de los fieles, no solamente quanto a los actos humanales de co(fol. 191v)mer y de hablar, y de qualquier dar e tomar, -79v- mas avn lo priua e aparta de la participacion de los su/f/fragios, beneficios e ayudas spirituales que comunmente se hazen en toda la Yglesia Vniuersal, de los quales no ha parte ninguna ${ }^{283}$ el descomulgado, para que por ellos sea ayudado a crescer en la gracia de Nuestro Señor y en las virtudes /y/ a salir de los pe/c/cados; como el miembro ya cortado y echado al muradal 284 o sepultado en el cimiterio no $>n<$ ha parte ninguna, nin rescibe ningund ${ }^{285}$ prouecho de la refeccion ${ }^{286}$ e mantenimiento que re $>$ s<cibe todo el cuerpo. Ni>n< tiene poder el tal peccador descomulgado para resistir a los demonios que no $>n<$ le tienten como quisieren, $y>$ que non< le derriben en muchos pe/c/cados, antes es /del todo/ sometido a la voluntad e poderio del demonio para que libremente haga en él lo que quisiere, desamparado y apartado del amparo e ayuda de Nuestro Señor e de su Sancta -80r-Yglesia.

[135] Segund que se conoscia desamparado el mal hermano Caym, veyendose echado de (fol. 192r) la cara de Nuestro Señor, y temia con razon que qualquiera lo mataria; y segund que en todos los bienes temporales del Sancto Job excepta la vida, tuuo poder el diablo, luego que Nuestro Señor $>l e<$ dio lugar e alçó dellos su mano. $Y$ assy lo hizo Sant Pablo a aquel luxurioso christiano de la cibdad de Corintho, que lo descomulgó e lo puso en la mano del demonio ${ }^{287}$. E si veemos que Sathanas no toma luego a los $>d<e s c o m u l g a d o s$ e no $>n<$ los atormenta hasta matarlos, esto dizen que haze con grand cautela porque, con temor de tan grand pena y de tan manifiesto daño, no $>n<$ se guarden los ombres de /peccar e de/ caer en ella. Pues, avnque la $>d<e s c o m u n i o n$ sea assy muy graue $>$ pena<, pero tanbien es medicina effizaz e muy entera. Ca todas las penas $-80 \mathrm{v}$. Son melezinas 288 de aquellos que pe/c/can y $>$ que $<$ son castigados e corregidos con ellas, y de los otros que por exemplo de aquéllos son

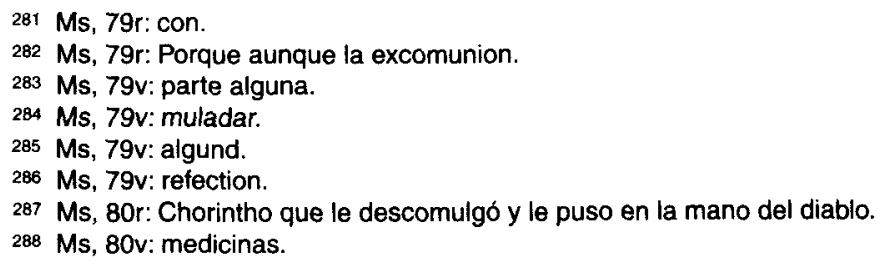


escarmentados y se retra/h/en de pec/c/ar e salen de los pec/c/ados por miedo de $>$ no $<$ ser assi pena(fol. 192v)dos.

[136] Por manera que, como el cauterio del su ego es muy graue e muy penoso pero quando no bastan >las < /otras/ blandas medicinas es

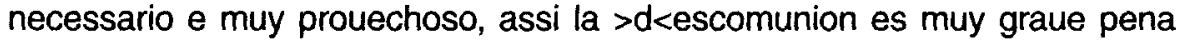
pero necessaria e /muy/ prouechosa quando no /h/ay otro remedio. Pues como en los comeres y en los trajes pueda auer e aya pec/c/ado e pec/c/ados mortales, segund pare $>s<c e$ por lo ya dicho, pueden e deuen los prelados ec $>c<l e s i a s t i c o s$ descomulgar a las personas que de tales dissoluciones y excessos no se quieren refrenar por miedo ni temor de otra pena temporal.

\section{[137] Capitulo XXI ${ }^{289}$, y mucho de notar, demuestra quando el ex-81r-cesso e superfluo comer e traher es pe/c/cado mortal.}

[138] Mas quales comeres e traheres se deuan juzgar superfluos e tan excessiuos y demasiados que sean e deuen ${ }^{290}$ ser condenados, e auidos por mortales pe/c/cados, cont/i/esso la verdad que es muy di/f/fici/(fol. 193r)le de determinar, porque en todas las cosas es verdad que es muy di/f/ficile y muy graue de conoscer el medio en que consiste la virtud. Y es mucho más di/f/ficile y más graue de le 291 tener y guardar, y, por consiguiente, es graue de $\mathrm{co} / \mathrm{g} /$ noscer quién se aparta mucho o poco dello 292 , $/ 10 /$ qual es pec/c/ar mortal o venialmente, ca pequeño apartamiento del medio y de lo justo es pec/c/ado venial, grande apartamiento dello, como fue apuntado arriba, es pe/c/cado -81v. mortal.

[139] Rég $>$ u<la se podria dar, que fue a $>$ r $<$ riba apuntada, que grand defecto e ${ }^{293}$ grand excesso e apartamiento de lo natural e razonable es pe/c/cado mortal en lo vno y en lo al. Mas es $>$ la< regla $/ \mathrm{más} / \mathrm{cier}$ ta y más general que para determinar y medir aquesto los sabios han hallado la prudencia e discrecion del varon prudente e sabio. Por manera que assi como auemos por prieto o por blanco, /o/ por bien o $>$ por $<$ mal colorado no $>n<$ lo que el /que/ tiene mala vista, ni>n mucho< menos lo que el ciego juzga ser tal, mas lo que juzga y determina aquél que tie(fol. 193v)ne clara e sana 294 la vista; e as/s/y como auemos por dulce o la/margo no $>n<$ lo que juzga el que está enfermo e tiene el paladar

\footnotetext{
289 Ms, 80v: quarto.

290 Ms, 81r: deuan.

291 Ms, 81r: 10.

$292 \mathrm{Ms}, 81 \mathrm{r}$ : poco o mucho del.

$293 \mathrm{Ms}, 81 \mathrm{v}: 0$.

$294 \mathrm{Ms}, 81 \mathrm{v}$ : sana y clara.
} 
dañado mas lo que juzga y determina aquél que lo tiene bueno e sano; e aquella auemos por buena armonia e -82r- dulce melodia 295 que juzga buena e suaue el que tiene >bueno $y<$ sano e bien ordenado 296 el sentido de oyr; e aquello auemos y deuemos auer por pesado $>\mathrm{y}<$ cargoso $o$ por liuiano que juzga ser tal no>n< el que está enfermo e flaco mas el que está rezio y esforçado. Bien assi, en lo bueno y en lo malo, en la virtud y en el peccado, aquello es bueno e virtuoso que aprueua por tal el varon prudente e sabio, $y>$ es < vicioso e malo lo contrario, aquello es obra de fortaleza, de liberalidad y de franqueza, de magnanidad 297 (sic) e magnificencia, que el varon prudente aprueua. E aquello es obra de miedo o de osadia y temeridad, de auaricia o $>$ de $<$ prodigalidad, de presumpcion o de pusillaminidad, de soberuia e ventosidad, o de pequeñeza que aquel varon prudente reprue(fol. 194r)ua.

[140] >E< assi a nuestro proposito aquel -82v-comer y beuer es honesto y templado, e no superfluo ni demasiado que juzga tal e aprueua el varon prudente e sabio, e aquello que él reprueua es intemperado, vicioso e sobrado. E otro tanto en el vestir e tra>h<er aquello es moderado e honesto que aquél aprueua por bueno; e aquello es >excesso<, /superfluo, deshonesto/ y pec/c/ado mortal o venial que aquél determina ser tal.

[141] Mas, quál será >este< varon prudente e sabio que esto sepa determinar tanbien confiesso que no es ligero de /a/ver, porque no es cada qual. Mas esta es la verdad: que >aquél 298 es y deue ser auido por tak $<$, que tiene en la republica officio e auctoridad de regir e /de/ gouernar. Ca no es otra cosa el juez y el 299 prelado e/c/clesiastico o seglar sino ley que tiene ánima para dezir y declarar la justicia e la verdad, y por esso manda Nuestro Señor que los oyamos e obedezcamos avnque -83r- sean phariseos, discolos e malos, en tanto que son tolerados.

[142] Uerdad es que / $h$ /ay muchos prelados e/c/clesiasticos e seglares que por ser ignorantes o por ser (fol. 194v) malos juzgan lo malo ser bueno e lo bueno ser malo, y entonces es el remedio del que verdaderamente se cree agrauiado appellar para el superior ${ }^{300}$, avnque no de la pena que se pone por ley general. E si el superior es peor que el inferior, que puede bien acaecer, forçado es de le obede $>$ s<cer, teniendo por cierto que si nos andamos con simpleza, por nuestra >simpleza<, obediencia e humildad Nuestro

$295 \mathrm{Ms}, 81 \mathrm{v}-82 \mathrm{r}$ : por buena y dulce armonia.

296 Ms, 82r: concertado.

297 Ms, 82r: magnanimidad.

298 Ms, 82v: el.

$299 \mathrm{Ms}, 82 \mathrm{v}$ : juez o.

$300 \mathrm{Ms}, 83 \mathrm{r}$; y entonçes es el remedio appellar para el superior el que uerdaderamente se cree agrauiado. 
Señor en lo que a nos toca no le consentiera ${ }^{30 t}$ errar ca assi lo tiene prometido e no puede faltar. E si todavia errare, sentenciando e ${ }^{302}$ juzgando contra $>$ la $<$ Ley Diuinal o contra el Derecho Natural, no deue ser obede $>$ s<cido como no obedescian ${ }^{303}$ los Apostoles a los pontifices e sa-83v-cerdotes porque lo que mandauan era manif/i/estamente contra Dios e conoscidamente /contra Dios y conosçidamente/ injusto, ni> $n<$ los martyres obede $>$ s $<$ cian en lo tal a los emperadores ni a sus adelantados.

[143] Capitulo XXII ${ }^{304}$. Demuestra por doze razones que aquel traje descomulgado de caderas e verdugos es muy malo ${ }^{305} \mathbf{e}$, por consiguiente, muy de(fol. 195r)uidamente reprobado y vedado. $E$ aqui toca de los afeytes quándo son pec/c/ado venial e quándo >pecado< mortal.

[144] Ya de todo lo susodicho 306 pare $>$ s $<$ ce claramente que pudieron la justicia y regimiento, e quien su poder touiesse para ello, defender que las dueñas non trax/i/es/s/en verdugos ni caderas e poner pena cerca dello. $Y$ pudo el prelado o juez ecclesiastico ${ }^{307}$ defender aquesto mesmo so pena de exco/m/munion, porque traer el tal hábito es cierto que era y es pec/c/ado mortal y en muchas maneras -84r- malo. $Y$ como quier/a/ que, segund lo que es dicho /en este passado capitulo/, bastaria por prueua desto que los varones prudentes e sabios, que son los regidores e prelados, lo han assi determinado, pero, por satisfazer a las personas curiosas e por conuencer a las maliciosas, /con licencia y supportacion de los dichos venerables prouisores/ es bien que sea aqui declarado cómo traer aquel/dicho/ hábito es en muchas maneras pe/c/cado, y de derecho diuino e humano defendido e reprobado.

[145] Lo primero, porque es hábito e traje ${ }^{308}$ noxio (sic) e muy (fol. 195v) dañoso ca se halla por cierto que muchas dueñas han mouido y abortado, y avn peligrado en el parto, e no a otra causa a quanto se puede saber sino por traer aquel maldito hábito pesado e mucho cargado, e a la conseruacion y defension 309 de la criatura mucho contrario. Pues, auido esto por presupuesto, $-84 \mathrm{v}$ - es cierto que son homicidas voluntarias las que del tal traje andan vestidas

\footnotetext{
301 Ms, 83r: consentirá.

$302 \mathrm{Ms}, 83 \mathrm{r}: 0$

303 Ms, 83r: obedeçerian.

$304 \mathrm{Ms}, 83 \mathrm{v}$ : quinto.

$305 \mathrm{Ms}, 83 \mathrm{v}$ : es graue peccado.

$306 \mathrm{Ms}, 83 \mathrm{v}$ : lo suyo.

$307 \mathrm{MS}, 83 \mathrm{v}$ : y pudieron los prouisores.

$308 \mathrm{Ms}, 84 \mathrm{r}$ : es traje y habito.

${ }^{309}$ Ms, 84v: y a la defension y conseruaçion.
} 
y arreadas ${ }^{310}$, lo qual es muy grand peccado. E si dizen las donzellas, e las biudas tanbien con ellas, que son quitas deste pe/c/cado pues que ellas 311 no paren ni enpreñan ni están en aquel estado, verdad es, mas sepan que las mugeres e avn muchas >de las< personas son como las ouejas: que por do va vna por alli van todas, especialmente en lo malo. E que no es ligero de dexar, antes dizen que es morir mudar lo acostumbrado, e por esso las que lo trayan donzellas no se pueden vencer a lo dexar ya hechas dueñas, assi que en alguna manera dan causa o fauor a que nasca aquel daño, y, dado que las biudas e donzellas que lo trax/i/essen no participassen en aquella manera de (fol. 196r) pec/c/ado, es cierto que no se puede $>n<$ excusar que non pequen tanto e más en las ma-85r-neras que se siguen.

[146] Lo segundo, es hábito luxurioso a las personas que lo tra $h<e n$, porque aquel mucho paño y aforro que traen cercado a las caderas es cosa muy natural que las escaliente demasiadamente e las prouoque ${ }^{312}$, por consiguiente, a mucho luxuriar. Por $>$ re $<$ medio fallaron los sabios para mitigar el ardor de la luxuria e para guardar la castidad traher planchas de plomo en los lomos y en el vientre que los ayan de effriar, o ${ }^{313}$ traer algun cilicio e paño aspero de sayal que con su aspereza e frialdad castigue e hostigue aquellas partes que han menester aspereza y açote más que blandura $>$ s nin otro $<314$ conorte. Pues, assi como es grand yerro en el comer $y>$ en el< beuer añadir sal a la cecina y a la sardina, y a la salsa de los ajos echar cominos, pimienta, genzibre ${ }^{315}$ e clauos, assi acá es gran/d/ yerro al fuego añadir -85v- fuego, y esto avn ${ }^{316}$ es mayor cargo a las que $>$ no< son casadas porque han de ser mas castas.

[147] Lo tercero, es >hábito < a la honrra e fama muy contrario porque comunmen(fol. 196v)te se $>$ cree $<$ que fue inuentado $>y$ es vsado< para encobrir los fornicarios e adulterinos preñados, por manera que todas las que los tra/h/en, buenas e malas, son auidas por sospechosas e infamadas; y avnque no sea a/s/si la verdad, pero ciertamente la qualidad e manera del dicho hábito lo faze /assi/ >mucho< sospechar. Pues, como la honrra e buena fama se deua mucho preciar, y en mucho tener y extimar ${ }^{317}$, y sea auida por cruel e muy deshonesta la persona que su honrra e fama menosprecia, grauemente pe/c/ca quien tal hábito tra/h/e que da causa de tanta sospech $>$ os $<$ a.

\footnotetext{
$310 \mathrm{Ms}, 84 \mathrm{v}$ : y adornadas.

$311 \mathrm{Ms}, 84 \mathrm{v}$ : porque ellas.

312 Ms, 85r: va tachado "demasiada".

313 Ms, 85r: $y$.

314 Ms, 85r: $y$.

315 Ms, 85r: gengibre.

$316 \mathrm{Ms}, 85 \mathrm{v}$ : echar fuego sobre fuego, y aun esto.

$317 \mathrm{Ms}, 85 \mathrm{v}$ : estimar.
} 
[148] Es, lo quarto, hábito desonesto e muy desuergonçado porque muy ligeramente descubre e demuestra los çancajos e las piernas, las quales ${ }^{318},-86$ r. como ar $>$ r $<i b a$ fue tocado, $>$ la $<$ naturaleza e vso comun e vniuersal >de todo el mundo,< desde Abinicio /acá,/ quiso que >las mugeres< especialmente traxiessen ${ }^{319}$ guardadas, occultas e cubiertas.

[149] Es, lo quinto, hábito escandaloso >e que ligeramente prouoca a luxuriar<, porque conoscido que escalienta y que es / $h$ /ábito oportuno para encobrir el preñado, ligeramente se atre(fol. 197r)uen los varones a requerir a las tales hembras /despertados y combidados por la uista de las piernas/. Pues dize el Sancto Euangelio que quien a otros escandaliza y les da causa de pec/c/ar mejor >le< seria con vna rueda de molino colgada de la garganta ser lançado en la hondura del mar, porque alli peligraria e padeceria el cuerpo e >solamente $<$ perderse ya la vida corporal, mas quien da scandalo, causa ${ }^{320}$ e oc/c/asion de pe/c/car pierde malamente su ánima, que es mucho de llorar.

[150] Es, lo sexto, hábito muy vano e sin ningun ${ }^{321}$ prouecho porque, avnque las caderas anden assi -86v- demasiadamente arropadas e por consiguiente muy escalentadas, pero dende abaxo todo anda hueco e apartado de las piernas ${ }^{322}$ por manera que no tiene el prouecho de ${ }^{323}$ cobrir e calentar para que el hábito fue fecho.

[151] Y avn digo más, que de aqui na/s/ce lo septimo, que es hábito peligroso e mucho enfermo en verano y en inuierno, porque como anda assi hueco e apartado /en el tiempo del invierno/ entra el ayre frio y el viento y penetra el vientre que está escalentado, e causa dolores de madre/s/y de vientres, que son comunes a las mugeres, y en verano calor muy demasiado. (iol. 197v)

[152] Lo octauo, es hábito mucho costoso, assy porque entra mucho paño /en él/ como porque cuesta >muy < mucho hazer, e porque se rae y se fastra muy ayna a causa de andar assipando y estirado, y despues de gastado apenas pueden aprouechar para otra cosa. E si a esto ${ }^{224}$ quieren dezir que ninguno -87 . deue tener cuydado que ellas gasten lo suyo bien o mal gastado, no es assi, /c/antes quiere/n/ todo derecho que los regidores y prelados prouean como ${ }^{325}$ ninguno vse mal de sus cosas porque en ${ }^{326}$ otra manera a la republica vernía grand daño.

\footnotetext{
$3+8$ Ms, 85v: que.

$319 \mathrm{Ms}, 86 \mathrm{r}$ : quiso que andouiessen.

320 Ms, 86r: quien da causa, escandalo.

$321 \mathrm{Ms}, 86 \mathrm{r}$ : algund.

322 Ms, $86 \mathrm{v}$ : e de las piernas muy apartado.

$323 \mathrm{Ms}, 86 \mathrm{v}$ : para.

$324 \mathrm{Ms}, 86 \mathrm{v}$ : y porque se trahe y gasta priador andando assipado y estirado, y despues de gastado apenas pueden del para otra cosa aprouecharse. $Y$ assi a esto.

325 Ms, 87r: que.
} 
[153] Y avn es por todo lo susodicho hábito enojoso a los más de los maridos, saluo que ${ }^{327}$ no lo osan dezir porque no quieren reñir sabiendo que no sersi<an creydos, lo qual, otrosi, a la dueña es ${ }^{328} \mathrm{gran} / \mathrm{d} / \mathrm{pe} / \mathrm{c} / \mathrm{cado}$. Porque en todo lo que no es malo es obligada a se conformar con el querer e voluntad de su marido, como el subdito religioso a la voluntad de su prelado.

[154] Lo dezeno, es ${ }^{329}$ /en alguna manera/ hábito muy vil, y de su condicion e primera inuencion a viles vsos deputado. Porque $>e<1$ traher de las faldetas, /las quales lo leuantan y enmoldan/, fue inuentado para las sieruas, que quan(fol. 198r)do se oc/c/upan en los -87v- oficios e seruicios ${ }^{330}$ humildes e suzios alçan e >ar<remangan las faldas de la saya por que no se les aya de ensuziar, e para guardar la honestad e quedar cubiertas /las piernas/ sup/p/len alli las faldetas, >las quales son y han de ser< de vil y gruesso paño, por que non ayan lastima de ensuziarlo. $Y$ avn eran antiguamente las faldetas hábito de cozineras y de regatonas y de triperas, ca las tales mugeres ponian las faldetas encima de las sayas por no $>n<$ las ensuziar, agora ya en lugar de aquellas vsan auantales de lienço, e fue buena auisacion por que se puedan lauar presto e $>$ porque $<$ no $>n<$ hazen mucho peso.

[155] Es, otrosi, hábito muy deforme e mucho feo ca las haze muy 331 gruessas $>e$ tan anchas como luengas $<$ /que parecen pipas o toneles çinchadas en lugar de arcos con los uerdugos y maruetes/. Uerdad es que es cosa natural a las mugeres ser baxas de cuerpo ${ }^{332}$, delgadas y estrechas de archas, y de pechos y de espaldas, y de pequeña/s/ cabeça/s/, y >que ayan delgadas $e<$ chicas >las<-88r- caras, y avn, como dize Sant $Y$ sid/o/ro, ser vn poco acoruadas ${ }^{333}$, como lo es y era la costilla ${ }^{334}$ de que fue formada la primera >muger<, y que sean 335 /otrosi/ anchas e gruessas de renes, de vien(fol. 198v)tres y de caderas por que puedan bien caber las criaturas que alli han de concebir y traher nueue meses ${ }^{336}$. $Y>$ todo esto es $y$ ha de ser naturalmente< por el contrario >en< los varones, y avn la Philosofia 337 Natural quiere y dize verdad: que >aqu<esto ha lugar en todos los machos $y$ hembras, tanbien en los arboles como en las aues y en las bestias.

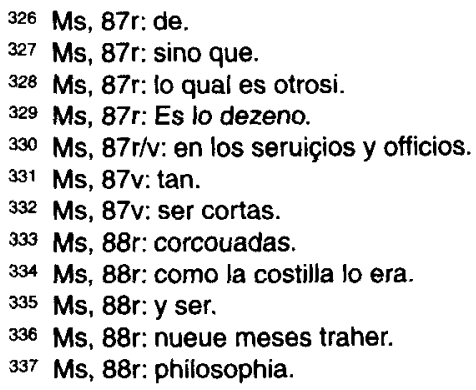


[156] Mas avnque esto sea verdad, excede el tal hábito mucho, y más que mucho, de la proporcion natural, $y$ en lugar de las hazer hermosas y bien proporcionados (sic) házelas feas, mostruosas y muy deformadas ${ }^{338}$, ca dexan de parecer mugeres y parecen canpanas, >y dezirse ya el como sy no pareciesse liuiano y algun poco vergunçoso<. /Quiça parecen más propiamente aquellos grandes cencerros que suelen llamar locajos, que trahen a los cuellos los bueyes y vacas -88v- quando andan grandes rebaños; $y$ digo que es más propia comparaçion que pareçen locajos, o si se puede dezir locajas, porque aquellos grandes cencerros no son assi redondos como lo son las campanas mas son vn poco quadrados o en alguna manera ochavados, y es assi la uerdad que aunque aquellas malditas faldas andan asazetyradas, más allá hazen algunos pliegues quatro o más grossachos 0 desdonados/. Parecen otrosi dragones rebentados ${ }^{339}$, segund que pintan a Sancta Marina quando rebentó con ella el diablo mudado en figura de dragon, ca de la cinta arriba parece/n/ a Sancta Marina y dela cinta abaxo >parescen< al diablo en semejança de dragon rebentado. $E$ avn ${ }^{340}$ parecen >como< serenas: de la cinta arriba mugeres y de la cinta ayuso cuerpo>s< de muy grandes aues o de grandes (fol. 199r) peces. $Y$ es propria esta comparacion pues, /por/que no es assi >en< la verdad, -89r- que aya pescado en el mar ni bestia ni aue en la tierra que sea la meytad ombre o muger, y la meytad pescado o bestia, mas como dize Sant Ysidoro fing/i/eronlo assi los poetas para dar a entender que fueron tres malas mugeres muy luxuriosas $e$ muy suzias que engañauan a muchos onbres; e fingen que tenian cuerpos de aues porque $>e<1$ amor parece que buela, y llaga como con vñas los coraçones en que assienta; e fingen que morauan en las ondas del mar porque las $>h<0$ das y el nauegar diz que prouocan a luxuria $>\mathrm{r}<$. /Parecen, finalmente, como dizia vn varon sabio, a los caualleros que hazen en la fiesta de Corpus Christi, o al reçebimiento de los reyes/. Tal vestidura dize Sant Ysidoro que se llama mastruga, que quiere dezir vestidura muy deforme e mostruosa /y peregrina/.

[157] /E contra las personas que trahen tal vestidura mostruosa y peregrina/ dize Sofonias ${ }^{341}$, propheta, que se ensaña mucho Nuestro Señor, -89v- y que las visitará e castigará asperamente con el açote de su furor.

[158] Es, finalmente, hábito de gran/d/ >ficcion< e muy mintroso. Gran/d/fic/t/ion es por cierto que la que es flaca y descaderada, seca e mucho delgada, haga caderas e cuer(fol. 199v)po de trapos y de lana, y avn si ${ }^{342}$ se

\footnotetext{
$338 \mathrm{Ms}, 88 \mathrm{r}$ : feas, muy deformes y monstruosas.

$339 \mathrm{Ms}, 88 \mathrm{v}$ : dragones pintados.

$340 \mathrm{Ms}, 88 \mathrm{v}$ : $\mathrm{E}$ tan bien.

341 Ms, 89r: Sophonias.

$342 \mathrm{Ms}, 89 \mathrm{v}$ : y aun quando.
} 
hiziesse templadamente alla podria passar, y, quando más, seria pe/c/cado venial. Mas, hecho por tal manera, tan sin mesura e tan demasiado, sin dubda es ficcion y mentira de grand culpa e grand pec/c/ado. Ca toda ficcion y simulacion que no es hecha para significar algun/d/misterio es mentira, e por consiguiente $\mathrm{pec} / \mathrm{c} / \mathrm{ado}$, porque toda mentira es pe/c/cado, agora sea de palabra agora >sea< de obra.

[159] No miente $>$ ni peca $<$ menos el que por obra $0>$ por $<$ obras fingidas muestra lo que no es que el que dize palabras que af/f/irman lo que no es $>0$ niegan lo que es $<$. Uerdad es que como >quier que $<$ toda mentira sea peccado, pero no es siempre peccado -90r- mortal, ca si el ombre miente /liuianamente/ por burlar y auer plazer sin dañar a ninguno no pe/c/ca mortalmente; ni avn si por hazer algun/d/ profecho syn hazer daño a ninguno ${ }^{343}$ miente tanpoco pec/c/a mortalmente. Mas si miente /reziamente/ en daño o en perjuizio de alguno entonces la >tal< mentira es pec/c/ado mortal /y grand culpa/, mayor o menor segun/d/ la qualidad e quantidad del daño que dello ${ }^{344}$ resulta.

[160] Pues as/s/i es de las fic/t/iones, que si alguna se finge hermosa con a $>f<$ feytes e colores, pelan(fol. 200r)do las cejas e poniendo alcoholes, etc., si lo haze liuianamente e no con intencion de atraher ni engañar a ninguno a que peque con ella ${ }^{345} \mathrm{pe} / \mathrm{c} / \mathrm{ca}$ venialmente, y si por aplazer a su marido e lo retraher de algun/d/vicio tanbien parece que es pe/c/cado venial; $y$ si es donzella y se afeyta por cobrar marido no la sabria escusar porque lo haze en perjuyzio -90v- de aquel a/l/ qual quiere engañar, ca seyendo fea se $>l e<$ vende por hermosa, pero ni tanpoco la oso conde $>m p<$ nar. $Y$ assi es en el vestir y en el calçar, que > peca grauemente < la persona que mucho excede de lo natural, fyng/i/endo con los chapines la altura que no $>n<$ tiene, con grand soberuia de parecer grande la que es pequeña, mayormente como Nuestro Señor aya querido que las mugeres sean comunmente pequeñas de cuerpo, e menores que los varones porque por ellos han de ser regidas como por mayores.

[161] >ltem, pecan grauemente ${ }^{346}<$ fing/i/endo con trapos e lana, e con faldetas y verdugos la gros/s/ura que no $>n<$ tyenen, pues, $>$ si añadimos que de la tal ficcion< se siguen 347 /de lo tal/ los males, daños y pec/c/ados que son dichos, no es du/b/da syno que tal fic/t/ion y menti(fol. 200v)ra sea $>$ gran $<$ peccado /e/ mortal.

\footnotetext{
343 Ms, 90r: a alguno daño.

344 Ms, 90r: della.

$345 \mathrm{Ms}, 90 \mathrm{r}$ : alguno a que con ella peque.

$346 \mathrm{Ms}, 90 \mathrm{v}: 0$.

347 Ms, 90v: Siguiéndose.
} 
[162] E assi ${ }^{348}$ pare $>S<c e$ por ${ }^{349}$ estas doze causas e razones que las caderas y verdugos son hábito muy dañado e muy malo, e que muy razonablemente fue de-91r-fendido, e so pena de exco $/ \mathrm{m} /$ munion $>$ mayor $<$ vedado, e como sea hábito tan des/h/onesto $>\mathrm{e}<\tan$ dissoluto e tan superfluo es defendido por todo derecho, que no consiente sino lo mesurado e $>10<$ honesto, y solo aqui escripto pare $>$ s $<$ ce mucho e riguroso. Lean la/s/ personas que assi lo piensan lo que los Sanctos Doctores escriuieron contra ello, especialmente Sant Cipriano obispo, y nuestro glorioso padre Sant Jeronimo ${ }^{350}$, e avn aosadas Sant Crisostomo, y verán quán tenpladamente es escripto esto e /aun/ quán blandamente es denostado aqui este pecado ${ }^{351}$.

[163] Pero esto se aya ${ }^{352}$ por cierto: que emendar lo que Dios hizo fingendo otros cabellos, otros ojos, otras cejas, otros colores en el rostro, otra statura y proporcion de cuerpo es graue offensa de Nuestro Señor e graue sacrilegio. Ca por injuriado $>r<e$ muy injuriado se ternia qualquier pintor o entallador del que quisiesse -91v- poner mano ( $(01.201 r)$ a emendar lo que él ouo pintado o entallado. $Y$ assi dize $>n<$ aquellos sanctos, y es terribile sentencia, que Dios no conoscerá, antes reprouará e muy ayradamente alançará > de sí< con los diablos a las personas que por tal manera en sus rostros y en sus cuerpos pusieron las ${ }^{353}$ manos. La qual sentencia se deue entender y templar como ya $>$ yo< la ${ }^{354}$ templé y declaré. Plega a Nuestro Señor que mi mucha /piedad e/ templança en aquesta parte no engañe e haga errar a algunas atreuiendose quiça más de lo que hasta aqui se atreuian, avnque si bien lo leen e bien lo miran e bien lo quieren guardar pienso que no podran mucho errar.

[164] Capitulo XXIII 355. Demuestra que los motiuos e razones de dubdar cerca de lo susodicho ${ }^{356}$ que al comienço fueron apuntados no son suf/f/icientes para im-92r-pedir ni estoruar que lo sobredicho no sea muy bien ordenado, y que deua ser muy bien guardado.

[165] Tanbien es ya /de/clar/ad/o de 357 lo susodicho que aquellos motiuos que al comienço fueron apuntados que mouian a creer que (fol. 201v)

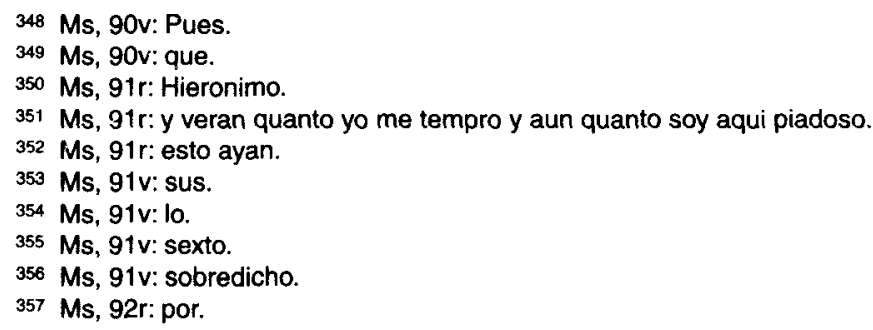


aquel maldi $>c<$ to $>$ habito $e<$ traje no se pudiesse vedar no son verdaderos. Ca no es assi que cada vno se pueda vestir a su voluntad, porque sy aquella voluntad es mucho desordenada non le ha de ser dado lugar, y assy es en /aqu/este caso. En el vestir no /h/ay regla cierta, verdad es para en cada cosa e cosa, porque $>\mathrm{e}<\mathrm{l}$ varon prudente e sabio que lo tal ha de reglar $>10<$ comete al aluedrio e voluntad de cada vno que traya lo que le agradare, tanto que no exceda mucho de lo natural e honesto e razonable. Pero si $358 \mathrm{mu}$ cho excede, como en nuestro caso acae $>\mathrm{s}<\mathrm{ce}$, el -92v- prelado eclesiastico o seglar lo ha de refrenar y ge lo ha de vedar. En cada tierra/h/ay e siempre vuo (sic) su vso: verdad es quando el tal vso no es mal vso, ca si el ${ }^{359} \mathrm{mal}$ vso no se ha de llamar vso syno abusion e cosa de confusion; $\mathrm{ni}>$ se ha de llamar< costumbre si es mala, mas corrupcion; y quando assi es no ha de ser consentido ni sofrido, y si se sufre aquello es por $>$ la $<$ malicia o 360 negligencia de quien lo ha de corregir. Y lo que de suyo es malo avnque se vse en todo el reyno e >avn< en todo el mundo no es por esso bueno. (fol. 202r) Toda carne corronpio su manera al tiempo del Diluuio mas non dexó por esso de ser graue pe/c/cado y castigado con aquella grauissima pena ${ }^{361}$. Todo el mundo ydolatraua saluo el patriarcha Abraham, mas muy grauemente $\mathrm{pe} / \mathrm{c} / \mathrm{caua}>\mathrm{n}<$. Solo Loth se halló bueno en Sodoma y Gomorra, mas destru-93r-yolas Nuestro Señor. En cada cabo juegan e blas/f/feman y quebrantan las fiestas, y apenas /h/ay quien lo castigue ni refrene ni se duela dello, mas no es por esso bueno. Assi que entonce $>$ s $</$ no/ excusa el vso quando io que se vsa no es conoscidamente malo de suyo como lo es en nuestro caso.

[166] Pare $>s<c e$, otrosi, que pueden sobre $>$ e<llo descomulgar, pues que /h/ay en ello pec/c/ado y pec/c/ados mortales muchos y mucho graues. El derecho no $>n<$ determinó enteramente el hábito clerical pero mandó que fuesse honesto, e >defendió< que non trax/i/essen los clerigos vestiduras bermejas ni verdes, ni abiertas ni partidas, ni hechas a mitades, ni muy cortas ni muy luengas, ni cosas de oro ni de plata, ni avn doradas ni plateadas etc. No se vieda >aquel mal traje< en todo el reyno porque /h/ay po(fol. 202v)cos $y^{362}$ en pocos lugares que zelen e procuren lo bueno, pero cada prelado y go-93v-uernador en su pueblo es obligado a vedarlo y el pueblo a obede $>$ s $<$ cerlo.

[167] Assi que cessan aquellos motiuos como no suficientes ${ }^{363}$ que hazian dubdar si el traje de las caderas y de los verdugos se deuio vedar en

358 Ms, 92r: Ca si.

359 Ms, 92v: ca si es.

360 Ms, 92v: y.

$361 \mathrm{Ms}, 92 \mathrm{v}$ : con aquella pena grauissima castigado.

362 Ms, 93r: ni.

$363 \mathrm{Ms}, 93 \mathrm{v}$ : como insufficientes. 
la muy noble villa de Valladolid ${ }^{364}$ e sy los prouisores pudieron sobre $>e<l l o$ descomulgar.

\section{[168] Capitulo XXIIII ${ }^{365}$. Demuestra que en la muy noble villa de Valladolid más que en otro >ningun < lugar se deuio aquello reprouar y vedar. E pone fin al tra/c/tado.}

[169] Para dar cabo e fin a este tractado es finalmente de saber que en aqueste nuestro tiempo no $>n</ h / a y$ lugar $>$ insigne $<$ en todo el reyno que tanto sea obligado a procurar y seguir lo bueno, $y>a<$ huyr y esquiuar 366 lo malo, como la muy noble villa de Valladolid. Porque es $>$ muy $<$ grande pueblo, de gente muy discreta $>$ poblado, $e<$ noble $>e<$ virtuosa y deuota en todo estado; en me(fol. 203r)dio del reyno como plaça collocado, de mucha lumbre de sciencia -94r- alumbrado, assi por razon de la Vniuersidad como por la Corte e C/h/ancelleria que en ella reside; de mucha justicia ciuil e criminal dotado, más que ninguna cibdad por razon de la dicha Corte e $\mathrm{C} / \mathrm{h} / \mathrm{ancelleria;}$ de exemplos de todas virtudes adornado, a/s/si por razon de la yglesia insigne que en él es, avnque collegial, como por los notables monesterios de todas religiones y de mucha obseruancia que en ella/s/ son; por notables predicadores en vida y en sciencia continuamente ex/h/ortado e amonestado. Por manera que no tiene excusacion ninguna ${ }^{367}$ esta muy noble villa de no hazer muy complidamente todo lo bueno $368 / y$ por entero/, e, como centro que más virtud recibe e tiene, comunicarlo a todo el reyno, /pues que tanto es ayudada para el conosçimiento y prosecuçion dello/, antes es digna de muy gran/d/ pena si es negligente e remissa >en lo bueno< porque a quien más -94v- dones Nuestro Señor da más le demandará.

[170] $Y$ avn hablando en este caso deste traje maldi $>c<$ to y muy deshonesto diz>en< que en esta villa ouo comienço, o fue luego ac/c/eptado, vsado e fauore $>$ s<cido. (fol. 203v) Pues manda Nuestro Señor que el que pozo o hoya abriere que el mesmo la cierre, y /que/ qualquier que diere $>$ e<scandalo e ocasion de pe/c/car trabaje de quitarlos con mucho bien obrar ${ }^{369}$.

[171] E assi acaba este tractado, hecho con muy sana intencion de excusar las offensas de Nuestro Señor >que muy a menudo y en toda parte se

$364 \mathrm{Ms}, 93 \mathrm{r}$ : en la muy noble villa de Valladolid se deuió uedar.

365 Ms, 93v: octavo.

$366 \mathrm{Ms}, 93 \mathrm{v}$ : y uedar.

367 Ms, 94r: alguna.

$368 \mathrm{Ms}, 94 \mathrm{r}$ : de no hazer lo bueno muy conplido.

$369 \mathrm{Ms}, 94 \mathrm{v}$ : e señuelo de peccar trabaje por tyrarlo conn mucho bien obrar. 
cometen en vestir y en calçar, y avn en comer y beuer </mayorrnente en este tienpo en que su yra primero con el açote de la seca, y despues su grand benignidad en la pluuia abondosa nos obligan a e $>n<$ mendar qualquier offensa o yerro aunque fuesse muy pequeño/. Pero si con aqueste zelo, feruor y desseo es aqui algo excedido, y no se ha tenido en todo la modestia y mesura deuida ${ }^{370}$, demando $>$ mucho $<$ perdon /dello a qualesquier personas que -95roffendí/ y ruego a Nuestro Señor que dé gracia y bendicion para que en todo conozcamos y hagamos su voluntad ${ }^{371}$. Amén.

[172] $\sim$ vos, señoras mias reduzidas a vuestra honestad, rogad por mí, peccador, a su Infinita Maiestad./

$370 \mathrm{Ms}$, 94v: deseo en algo aqui excedi y no he tenido la modestia y mesura que deuí.

$371 \mathrm{Ms}, 95 \mathrm{r}$ : rogando a Nuestro Señor tal qual so que a ellas y a mí de gratia e facultad para en todo conosçer y hazer su uoluntad. 


\section{ÍNDICE DE LUGARES}

BABILONIA (ciudad), 100

Campo Damasceno, 48

Cantuaria vid. Canturia

CANTURIA, 97

CORINTO, 135

EGIPTO, 118

ESPAÑA, 1

GOMORRA, 165

GRANADA, 1
GRECIA, 103

ISRAEL, 20, 112, 118, 126, 127

SABA, 106

SALAMANCA, 98

SAMARIA, 97

SIRIA, 86

SODOMA, 165

TierRa de Campos, 1

VALLADOLID, villa, 1, 25, 36, 167, 168, 169 


\section{INDICE DE MATERIAS}

A

ABAstados, 124

ABORTO, 145

ABORTONES, 98

ABRoJos, 96 (nota 174)

ABstinenCia, 76, 77, 88, 110

ABUNDANCIA, 89, 100

- de bienes temporales, 123

ABusión, vid. abuso

ABuso/s, 165

Acros

- de los Apóstoles, 100

- humanales, 134

ADELANTADO/s, 142

ADULTERINOS, vid. adúlteros

ADÚLTEROS, 147

ADVERSIDAD, 63, 72

AfEITES, 23, 143, 160

AfLiCCIÓN, 64, 72, 77

AGUA, 47, 76, 116

- del Bautismo, 78

- limpia, 75

- salada, 75

AguJEROS, 28

AIRE FRIO, 151

AJOS, 146

Albanegas

- tejidas con filetes levantados, 104

- llanas, 104

Alcandoras, 104

ALCOHOLES, 160

AlCoRques, 84, 103

- forrados de paño, 84

- forrados de seda, 84

Aldeanos, 112

ALEGRIA, 63, 110, 111

Alhareme, 103

ALHORZAS

- chamorras, 104

- francesas, 104

ALJuBAS, 52, 84, 104
ALJUBILLAS, 103

ALMA/S, 30, 80, 149

ALMACRACAS, 103

ALMANACAS, 52, 104

Almendras, 74

AMARGO, 139

AMBICION, 103

AMOR, 118, 120, 156

- natural, 120

AMPARO DIVINO, 134

ANCIANOS, 55

ÁNGELES, 38, 124

ANILLOS, 104

ÁnIMA, vid. alma

ANIMALES, 98 , vid. bestias

- recién nacidos, 75

- que comen los hombres, 74

ANIMALIAS, vid. animales

AÑOS, 76

APARADOR, 86

APARATO, 129

APETITO

- de pecar, 127

APOCALIPSIS, 49, 100

Apóstol, EL, 28, 47, 48, 57, 59, 91, 100 , 114,117

Apóstoles, Santos, 20, 27, 100, 104, $126,130,131,142$

ÁRBOLES, 155

ARCA/S, 7, 103

- de Noé, 77, 78

- estrechas, 155

ARcos, 155

ARCÁNGEL GABRIEL, 38

ARDOR, 18, 83, 115, 116, 118

- de la lujuria, 146

ARMONIA, 139

ARRACADAS

- de los collares, 104

ARTE

- de vestir y calzar, 131

- de hacer chapines, zuecos y calzado, 131 


\section{ARZOBISPO}

- de la Iglesia de Granada, 1

- de Canturia, 97

AsPEREZA, 129

Atavio, 103, vid. hábito, vestido, vestidu-

ra, vestimenta

- de las mujeres, 132

AUTORIDAD, 34, 36, 141

AVANPIÉS, 84

AvantALES, vid. delantales

AVARICIA, 14, 87, 89, 91, 139

AvelLanAs, 74

AVES, 77, 155, 156

- cazadoras, 28

- con pollos, 74

AYUDA/S, 134

AYUNAR, 128

AZOR, 77, 116

AZOTE, 157, 171

AZUFRE, 104

AZUL, 103, 108, 127

8

BALANDRÁN, 103, 104

- monjil, 84

- tabardo, 84

BALDRESES, 98

BANDAS, 103

BARBA, 60

BASILEO, 103

BATEO, 114

BAUTISMO, 78

BECA, 103

BECERRO, 80

BELLIOTAS, 74

BendeCidOS, 124

BENDICIÓN, 86, 171

BENEFICIOS, 134

BENIGNIDAD, 171

Bermejalo, 48, 103, 166

BESTIAS, 77, 155, vid. animales

- de rapiña, 77

- mitad hombre, mitad mujer, 156

- mitad pescado, mitad bestia, 156
BIEN/ES, 89

- público y común, 124, vid. república

- temporales, 123, 124, 135

Bisso, 68, 100

BLANCO, 100, 103, 139

BOCADO, 116

BODA, 111, 114, vid. casamiento

BoLSA/S

- de seda, 103

- de lana, 103

- labradas, 103

BONETE/S, 84, 104

- azul, 103

- bermejo, 103

- doblados, 103

- hendidos, 103

- levantados, 103

- metidos y encasquetados, 103

- morados, 103

- negro, 103

- pardillo, 103

- sanos, 103

- sencillos, 103

- verde, 103

BORZEGUI/ES, 84

- anchos, 103

- apretados, 103

- con bandas, 103

- de mil colores, 103

- estrechos, 103

- sin bandas, 103

BOTAS, 94

- anchas, gruesas y atacadas, 103

- delgadas y estrechas, 103

- francesas, 103

Bradas, 104

BRAONES, 103

Brazo, 94, 104

Bretañas, 96

BRIAL, 84

- de brocado, 104

- de fustán, 104

- de paño, 104

- de seda, 104

BROCADO/s, 64, 98, 103, 104, 108 
BUEY, 80, 156

BURIEL, 108

C

Caballero/s, 64, 94, 103, 112

- de pequeño y gran estado, 94

- santos, 96

CABELladura, vid. cabellera

CABELLERA, 58

- larga, 59

- de la mujeres, 130

Cabello/s, 60, 104, 163

- aleznados, 103

- alzados, 103

- cercenado, 60, 103

- con estudio hechos, 103

- encrespados, 103

- largo, 52, 103

- muy peinados, 103

- trasquilado, 60

CABEZA, 28, 61, 103, 104

- cubierta, 7, 56-58

- descubierta, 7, 56, 57

- pequeña, 155

- rapada, 60

- raída, 61

CABEZONES labrados, 36,103

CABRITO, 80, 81

Caderas, $36,103,121,143,133,146$, $150,158,162,167$

- anchas y gruesas, 155

- arropadas y escalentadas, 150

Caireles

- de aro, 103

- de seda labrados, 103

CALOR, 151

- del estómago, 72

CALZADO, 8, 62, 89, 91, 103, 131

- supérfluo, 131

CaLzas

- abiertas, 103

- cerradas, 103

- con chinelas, 103

- con pies, 84
- de soleta, 103

- italianas, 103

- sin chinelas, 103

- vizcaínas, 103

CAMA, 103, 104

CAMARRO, vid. zamarro

Cambiadores, 30

Cambrais

- de lino, 104

Camello, 58

Camino

- de penitencia, 28

Camisa, 103

Camisones, 36

- bastillos, 103

- con cabezones labrados, 36, 103

- cortos, 103

- delgados, 103

- largos, 103

- plegados, 103

- randados, 103

Campanas, 156

CAMPO, 58

CAMUESAS, 74

CAPA, 103

Capapuz, 84

Capellos

- de pequeño ruedo, 103

- de gran ruedo y beca, 103

Caperuzas, 103

CAPITÁN, 118

CAPUZ, 103

CARASS, 52

- delgadas y chicas, 155

- de Nuestro Señor, 135

CARBÓN, 98

Carboneros, 98

CARIDAD, 78, 118, 120

CARMEÑolas, 103

CARNAL, 112, 114

CARne/s, 75-77, 96, 97, 165

- con sangre, 32

- crecidas y hechas, 74

- cubiertas, 44, 46

- de poco precio, 118

- nuevas, 74 
CARNIELES, 103

Carrillos, 116

Carro de fuego, 51

CASA, 47, 55

- de los reyes, 96

CASADAS/os, vid. dueñas, hombres casados, mujeres casadas

Casamiento, 110

CASTA, 77

CASTAÑAS, 74

CASTIDAD, 146

CAUCE, vid. madre 1

Caudillo, 118

CAUSAS, 2, 26, 124, 162

- de pecar, 125, 149

- necesarias, 33

- propincuas, 33

Cautela, 135

Cebollas, 118

CeCInA, 146

CEJAS, 160, 163

CELO, 171

Cementerio, 134

Cencerros, 156

Ceniza, 64

Cercillos, 104

Cerco, 97

Ceremoniales, 32

Cerveza, vid. servicia

Cerviz, 32

Chancillería, 169

ChaPINERÍA, 131

ChaPINES, 131, 160

- altos, 84, 104

- castellanos, 104

- labrados, 104

- valencianos, 104

ChERRION, 84

ChINELAS, 103

CIBO, 100

CIDRAL, 49

CIEGO, 81, 139

Cielo/s, 38 (nota, 52), 74, 103, 128, vid. paraiso

CIENCIA, 169

CILICIO, 96, 97, 146
CINTA/S, 84, 103, 104, 156

- anchas de caderas, 103

- angostas, 103

- apretadas, 103

- broñidas, 103

- de hojas de higuera, 47

- de oro, 104

- de seda, 104

- flojas, 10

CINTADAS, 104

CINTERO, 84

CINTO/s, 84

- labrados, 103

- llanos, 103

- moriscos, 103

CIUDAD, 100, 123, 124, 131, 135

Ciudadano/s, 94, 123-125

Clavo, 146

Clérigos, 42, 55, 166

Coberturas, 103

COCAS, 92

COCINERAS, 154

CODERA, vid. codo

CODICIA, 100, 118

- carnal, 127

- de saber, 7, 39

$\mathrm{CoDO} / \mathrm{s}$

1. (indumentaria)

- con braones, 103

- costosos, 103

- dañosos, 103

- deformes, 103

- plegados, 103

- simples, 103

- sin braones, 103

2. (medida), 84 (nota 148)

CODORNICES, 118

Cogombros, vid. cohombros

Cohombros, 118

COLACIÓN/ES, 85

Coleta, 59, 61

Collar/Es, 52, 103, 104

- anchos, 103

- apartados, 103

- engrudados, 103

- forrados de paños, 103 
- justos, 103

- pegados, 103

COLODRILLO, 59

COLORADO/A, 109, 139

Colores, 64, 103, 106, 108, 160, 163, vid. azul, bermejo, blanco, colorado, morado, negro, pardillo, púrpura y verde

COMER

- y beber, 11, 12, 15, 16a, 17, 18, $67,70,71,73,88,91-94,101,102$, $109,110,116,120,122,140,146$, 171

- y hablar, 134

- y traer, 106, 137, 138

- y vestir, 10,68,69, 115, 116

COMIDAS, 85

COMINOS, 146

Comparación, 106, 156

COMPLEXIÓN, vid. composición

- caliente, 71

- humana, 76

- recia y sana, 75

COMPOSICIÓN

- de los varones, 103

Compostura, 45,66

- de la mujer, 12

Comunión, 118

CONCIENCIA, 104, 119

CONCORDIA, 78, 80

CONDENA, 91

- de las almas, 30

CONDENACIÓN, vid. condena

CONDENADOS, 120

Condestable, 111

CONDICIÓN, 119

- natural, 57

CONEJO, 77, 102

CONFESOR, 1

CONFUSIÓN, 52, 165

CONSENTIMIENTO, 38

CONSOLACIÓN, 112, 119, 124

Consuelo, vid. consolación

COPAGORJAS, 103

CORAZÓN, 156

- del rey, 34
CORCHOS, 104

CORDERINAS, 98

CORDERO/s, 28, 77, 80

- Pascual, 118

CORDONES, 103

- azules, 127

COROCHAS

- con hombros golpeados, 103

- llanos, 103

- marvetados, 103

- plegadas, 103

CORONA REAL, 103

CORPETES

- de oro broslados, 104

- de seda labrados, 104

Corpus Christi, 156

CORREgIDORES, 121

CORRUPCIÓN, 165

CORTAPISAS, 104

CORTE, LA, 169

CORTINAS, 103

COSASS

- bajas, 124

- curiosas, 104

- de fuera, 55

- de oro, 166

- de plata, 166

- descomulgada, 91

- desordenada, 91

- despreciadas, 124

- doradas, 166

- futuras, 33

- natural, 5-7, 39, 44-46, 50, 53-57, $63,71,72,146,155$

- no natural, 52

- no necesaria, 52

- plateadas, 166

- razonable, 71, 72

- temporales, 55, 119, 124

- vergonzosa, 104

Costilla, 155

Costra

- de la fruta, 75

Costumbre/s, 165

- deshonestas, 103

- honestas, 103 
COTAS, 104

COTE, 98

- de garras, 98

Crespina

- de oro, 104

Criatura/s, 52 (nota 76), 145, 155

CRISTIANO/S, 100

- lujurioso, 135

CuAdRÚPEDOS, 74

CuARESMA, 112, 114

CuBRICHELES, 103

- encordados con cordones, 103

- encordados con cintas, 103

Cuello, vid. collar

CuERDA, 103

CUERO/S, 66

- viejos, 28

CuerPo/s, 134

- delgado, 155

- de aves, 156

- de pescados, 156

- de trapos y lana, 158

- pequeño, 160

Cuesoueras

- de los carboneros, 98

- de los hombres pobres, 98

- de los pastores, 98

- de los segadores, 98

Culebra/s, 28

- maldita, 29

CURIOSIDAD, 129

Cruz, LA, 48,78

Ç

ÇUfRE, vid. azufre

D

DAGAS, 103

DAÑo/s, 28, 124, 145, 159, 161

- manifiesto, 135

- a la república, 152

DEDO/s, 78, 79, 104

- consustanciales, 78
DefECto, 39, 139

Delantales, 154

DELEITACIÓN, vid. deleite

DELEITE/S, 18, 83, 93, 96, 115, 116, 119,

124,128

- carnales, 123

DEMONIOS, 134, vid. diablo

DePILACIÓN DE CEJAS, 160

DERECHO, 166

- canónico, 42

- divino, 144

- humano, 144

- natural, 142

DESEO, 118, 171

- natural, 77

DESHONESTIDAD, 48

DESIERTO, 103, 118, 128

DESORDEN, 123

DESORDENACIÓN, vid. desorden

Destierro, vid. pena de destierro

DEUDAs, 120

Deudos, 120 (nota, 239)

DíA

- de abstinencia, 110

- de casamiento, 110

- del juicio, 49, 91

DIABLO, 135, 163

- con figura de dragón, 156

Diadema, 104

DIFUNTOS, 114

DiGESTIÓN, 75

DILIGENCIA, 123

DILUVIO, 75, 77, 78, 165

DIos, $12,20,32,34,38,84,89,98,103$, $126,142,163$

- humanado, 20, 126

- crucificado, 78

DIOSES, 60, 127

- sabientes, 37

Discipulos, 33, 34, 124

DISCRECIÓN, 139

Discretiva, 39

DisoluCión, 52, 60, 103, 136

DoCTORES, Santos, 20, 126, 131, 162

- antiguos, 20, 126

- modernos, 20, 126, 132 


\section{DOCTRINA, 27 \\ DOLOR/ES, 64 \\ - de madre, 151 \\ - de vientre, 151}

DOMINGO, 112

DON/NES, 32, 86

DONCELES DEL REY, 76

DONCELLA, 96, 107, 145, 160, vid. mujer

DRAGONES, 156

DuEÑAS, 4 (nota 2), 40, 84, 96, 100, 103, 104 (nota 203), 114, 119, 130 (notas, $259,261), 144,153$, vid. mujeres casadas

- grandes, 103

- pequeñas, 103

DULCE, 139

DUQUE, 118

E

ECLESIÁsticos, 55, vid. gobernador, juez, pastores, personas, prelado y sabio

EDAD, 71

EGIPCIOS, 127

EGo, 136

EJEMPLO/S, 108, 120, 135, 169, vid. prácticas.

EJERCICIOS, 71

EMPERADORES, 142

ENCANTADORES DE SERPIENTES, 28

ENCARNACIÓN, 37

ENFERMO, 139

ENTALLADOR, vid. tallador

ENTENDIMIENTO, 39

ESCÁNDALO, 34, 149, 170

ESCARCELAS, 103

Escribanos, 30

ESCUDEROS, 61, 94, 103, 112

Escudilla de lentejas, 117

EsPaLdA, 155

ESPECIE, 77

ESPIRITU, 71

- Santo, 48,78
ESTADO, 93, 94, 96, 99, 105, 119

- seglar, 103

- real, 107

ESTATURA, 163

ESTERILIDAD, 1, 72, 81

ESTOMAGO, 52, 72

ESTRADO, 104

Estudio, 117, 123, 125

- demasiado, 104 (nota 203)

ExCESO, 14, 87, 93, 100, 103-105, 109, $110,119,120,122,136-140$

ExCOMULGADO, 134

EXCOMUNIÓN, vid. pena y sentencia

EXCUSA, 169

EXCUSACIÓN, vid. Excusa

EXEQUIAS, 114

EXTRAÑOS, 120

Evangelio, Santo, $68,104,105,111$, $114,120,149$

EVANGELISTA, 100

$\mathbf{F}$

FAJA, 84

FALDA/S, 84, 104, 107, 154

- asazetiradas, 156

- con pliegues, 156

- cortas, 104

- largas, 104

- redondas, 104

Faldetas, 84, 104, 154, 161

- de paño, 154

FAMA, 147

FAMILIARES, 106

FARISEOS, 30, 141

$\mathrm{FE}, 78$

FELICIDAD, 103

FERVOR, 171

Festinancia, 118 (nota, 229)

FICCIÓN, 158, 160, 161

FIELES, 129, 134

FIELTRO, 103

FIESTAS, 85, 112, 114, 165

- del Corpus Christi, 156 
FILeTES, 104

Filosofía Natural, 155

FILÓSOFO, 131

FIMBRIAS, 127

FIN, 123

FiRMULles, 104

FLAQUEZA

- del entender, 39

FORNICARIOS, vid. fornicadores

FORNICADORES, 147

FoRRo/s, 66, 146

- de grises, 94

- de martas, 94

- de peña, 94

ForTALEZA, 139

FRANQUEZA, 139

FRENTE/S, 59, 104

Frío, 46, 91

FRUTAS, 75

- agrias, 72

- dulces, 72

- gruesas, 75

- provechosas, 75

- secas, 72, 74, 77

- tiernas, 75

- verdes, 72, 74

- zumosas, 75

FuEgo, 104, 146, vid. infierno

- infernal, 120

FUSTÁN/ES, 66, 103, 104

FUSTEDA/S, 66, 103

G

GABÁN, 94, 103

GABARDINA, 103

GaLGo, 77

GaLOCHAS, 103

GARGANTA, 52, 149

GARRAS, 98

GARZA, 77

GATO, 77, 80

GÉNESIS, EL, 57

GENGIBRE, 146
GENTE

- discreta, 169

- seglar, 103

GENTILES, 60, 64, 80

GENZIBRE, vid. gengibre

GLORIA, 106

GoBERNADOR/ES, 2, 26, 34, 124, 166

- eclesiásticos, 123

- seglares, 123

GONELAS, 104

GoRgUERA/s, 52, 104

- basta, 52

- delgada, 52, 104

- labrada, 104

- randadas, 104

Gracia, 78, 171

Grana, 100

GRISES, 94

GUANTES

- de nutria, 84

- de rebezo, 84

GuISADOS, 16a, 101

H

НА́BITO, 45, 127, 134, 144, vid. ropa, vestido, vestidura, vestimenta

- cargado, 144

- clerical, 166

- contrario a la honra, 147

- corto, 55

- costoso, 152

- dañado, 162

- deforme, 155

- de cocineras, 154

- de judios, 127

- de paño, 64

- de regatonas, 154

- de triperas, 154

- de la mujer, 130

- deshonesto, 19, 21, 121, 133, 134, 148, 162

- desproprorcionado, 156

- desvergonzado, 148

- disoluto, 162 
- entermo, 151

- enojoso, 153

- escandaloso, 149

- feo, 155

- honesto, 42, 130, 166

- honrado, 97

- largo, 55

- lujurioso, 146, 149

- maldito, 165

- malo, 162

- mentiroso, 158

- moderado, 130

- oportuno para cubrir el preñado, 149

- peligroso, 151

- peregrino, 121

- pesado, 144

- pomposo, 55

- supérfluo, 132, 162

- temperado, 130 (nota 261)

- vano, 150

- vergonzoso, 130 (nota 261)

- vil, 154

HamBre, 91, 116, 124, vid. mengua

HAMBRIENTO, 89

HASTIO, 119

HAZ, 94

- de la tierra, 75

Hechos de los Apóstoles, vid. Actos

HEMBRA/s, 6, 37 (nota 51), 38, 53, 75, $103,149,155$, vid. dueña, mujer

HERENCIA, 124

Hermano, 117, 120

- malo, 135

- mayor, 120

HIDALGOS, 112

HIGUERA, 47

HiJO

- de Dios, 38, 78, 126

- de Israel, 127

- malo, 111

HOJAS

- de higuera, 47

HolANDAS, 96

HOMBRERAS, vid. hombros

Hombres, 28, 37, 74, 75, 84, 104, 134,

156 , vid. varón
- ancianos, 55

- buenos, 123

- contentos, 103

- de bien, 94 (nota, 167)

- de honor, 94

- desenfrenados, 118

- golosos, 118

- honrados, 55

- infruitos, 118

- malos, 123

- pobres, 98

Hombros

- con braones, 103

- costosos, 103

- dañosos, 103

- deformes, 103

- golpeados, 103

- plegados, 103

- simples, 103

- sin braones, 103

HOMICIDAS, 145

HOMICIDIO, 32

HONESTAD, 14, 52, 55, 87, 88, 103, 127 ,

154,172

- natural, 84 (nota 149)

HONESTIDAD, vid. honestad

HONRA, LA, 147

HONRAS, 123

HOYA, 170

HUESTE de Israel, 118

HuMANIDAD, 69

HUMILDAD, 14, 38, 87, 88, 142

I

IDÓlatRAS, 60, 127

IDOLATRÍA, 61

ÍDOLOS, 107

IGLESIA, 134, 164

- colegial, 169

- de Granada, 1

- universal, 134

IMÁGENES, 107

IMPLAS ROMANAS, 104 
INFIERNO/s, 30,
120, vid. fuego

INJURIAS, 89, 124

INOCENCIA, 48

INTELIGENCIA, 80

INTENCIONES, 28, 160

INVENCIÓN/ES, 18, 115, 119, 120

- de la camisa, 103

INVIERNO, 63, 72, 74, 85, 151

IRA, 120, 171

J

JACTANCIA, 88, 95

JAZMINES, 49

JOYELES, 104

JUBÓN/ES, 84

- de brocado, 103

- de fustán, 103

- de fusteda, 103

- de paño, 103

- de seda, 103

- mitad falsado, 103

Judios, 64, 80, 103, 118, 127

- honestos, 108

JUEGOS, 114

JUEZ, 32, 118, 141

- eclesiástico, 144

JuICIO, 49, 91, 122

JUNCO, 36, 47

JUSTICIA, 141, 144

- civil, 169

- criminal, 169

Justos, 49

$\mathbf{L}$

LABRADORES, 61,94

LACERÍA, 94

LANA, 103, 127, 158, 161

LAZOS, 103

LECHE, 75

LEGUMBRES, 76

LENTEJAS, 117
LEON, 80

LEPRA, 86

LETRADOS, 55

LEY/ES, 125, 129, 130, 141

- de Jesucristo, 129

- de Moisés, 32

- de los comeres, 122

- de los trajes, $4,19,20,121,122$, $126,127,130$

- divina, 142

- evangélica, 124

- general, 142

LIBERALIDAD, 139

LIBERTAD, 34

LICENCIA, 144

- para comer carne, 75

LIEBRE, 77

LIENZOS, 154

- costosos, 96, 100

- delgados, 96, 100

- fino, 100

LIGEREZA, 37,55

LIMBO, 120

LINAJE humanal, 78

LINO, 66, 98, 104, 127

LIRIO, 106

LIVIANDAD, 119

LOBA (indumentaria), 103

LOBO, 77, 80

LOCAJOS, 156

Locos, 103

LODO, 55

LoMOS, 146

LOORES, 106

LOZANIA, 60

LUGAR, 25, 63, 100, 166, 168, 169

- santo, 51

LUJURIA, 103, 146
LL

LLAmAs, 104

LLORO, 63, 110

LLUVIA, 171 
M

MACHOS, 155

MADERO de la cruz, 78

MADRE/S, 75

- del hijo de Dios, 38

1.75

2. 151

MADROÑOS, 74

MADUREZ, 55

MAGESTAD DIVINAL, 49, 172

MAGNANIMIDAD, 139

MAGNIFICENCIA, 139

MAL/ES, 30, 37, 39, 103, 123, 124, 161

MALICIA, 34, 103, 165

MALDECIDOS, 124

MALDICIENTES, 28 (nota 36).

MALDICHOS, vid. maldecidos

MaLOS, Los, 30, 31, 113, 125, 141, 142

MANCEBO, 71, 103

MANDAMIENTO/s, 2, 26, 29, 32

- ceremonial, 32

- de regidores y prelados, 27

- del sábado, 34

- judiciales, 32

- morales, 32

MANGAS, vid. puñetes

- abiertas, 103

- buidas, 103

- cerradas, 103

- de los camisones, 103

- enteras, 103

- fruncidas, 103

- justas, 103

- prietas, 94

- trencadas, 103

MANiLLAS, 104

MANJAR, 81

- del cielo, 128

MANO, 78, 136, 163

- del demonio, 135

- del diablo, vid. del demonio

MANTENIMIENTO, 33, 71, 80-83, 105, 116 , 134

- celestial y milagroso, 103

- de las almas, 80
MANTO/s, 58, 104, 108, 127

- azul, 108

- cairelados, 104

- cintados, 104

- con gonelas, 104

- con los hombros golpeados, 103

- lombardo, 84, 104

- llanos, 103

- marvetados, 103

- plegados, 103

- sevillano, 84, 104

- viejo, 94

MANZANAS, 74 , vid. peros reales

MAR, 74, 149, 156

- Océano, 75

MARIDO/S, 105, 119, 153, 160

Marlotas, 104

MARTAS, 94

MÁRTIRES, 142

MARVETES, 155

MASTRUGa, 156

MAYORAZGO, 117

MECHUELA (de cabellos), 104

MEDICINA/s, 15, 136

- blandas, 136

MELEZINA/s, vid. medicinas

MELODIA, 19

MENESTEROSO/S, 89

MENGUA, 28, 72, 81, 91, 124, vid. hambre

MENTIRA, 84, 158, 159

MENUDENCIAS, 127

MÉRITO, 39 (nota 57)

MESA, 116

Mesías, 80

MESURA, 158, 171

MIEDO, 124, 136, 139

MilagRos, 33, 78

Milano, 116

MIMBRES, 47

Ministros, 106

MISA, 85

MISTERIO, 78, 98, 103, 158

- de la Encarnación, 37

MOdestia, 103, 171

MOLINO, 149

MOCEDAD, 119 
MOLLiCIE, 96

Monasterio/s, 169

- de Santa María de Prado, 1

- de todas las religiones, 169

MONJES, 97

MOÑos, 104

MoRAdO, 103, 108

Motivos, 164, 165, 167

Mozo, 80

Mozuelos, 114

MUERTE, 29

- de Nuestro Redentor, 37

- de Herodes, 100

MUJER/ES, 7, 12, 16b, 34, 36-39, 52, 54-

$57,59,63,71,84,103-105,119,127$, $130,132,134,148,151,155,156$, 160

- aliñosa, 106

- casadas, $36,52,58,132$, vid. dueñas

- doncellas, 36, vid. doncellas

- grandes, 36

- hacendosa, 106

- lujuriosas, 159

- pequeñas, 36

- que crían, 52

- que engañan a los hombres, 156

- sin casar, 132, vid. doncellas

- sucias, 156

- virtuosa, 106

MULADAR, 134

MUNDO, 47, 78, 103, 119, 124, 147, 165

MURADAL, vid. muladar

N

NARICES, 118

NATIVIDAD, 124

Natural., Lo, 67, 94, 139, 160, 165

Naturaleza, 59, 74, 148

NEBLI, 77

NECESIDAD, 84 (nota, 149)

Negligencia, 169

NegociadorES, 30

NEgRo, 103, 104
NIÑEZ, 119

NIÑOS, 48

NOBLES, 112

NOVEDADES

- de vestiduras, $16 \mathrm{a}, 103$

- en los colores, 103

NuDo, 36

NUECES, 74

NUTRIA, 84

o

ObeDiencia, 142

OBISPO, 162

OBRAS, 28

- de reposo, 55

- fingidas, 159

- intelectuales, 55

OfENSAS, 171

Oficiales, 61, 94, 112, 131

OFICIO/S, 6, 53-55, 71, 123, 141

- humildes y sucios, 154

- principal, 125

OíDo, vid. sentido

OJos, 163

OLAS DEL MAR, 156

ONÇA, vid. osa

ONDAS, vid. olas

Oratorio, 103

OreJas, 28, 52, 104

OVEJAS, 28, 74, 80, 103, 145

Oro, 66, 89, 100, 104, 130, 166

OSA, 80

Osadía, 139
$\mathbf{P}$

PACIENCIA, 89

PADRE/S, 105

- Eterno, 78

- primeros, 47-49, 98

- venerables, 36 (nota 47) 
PAJA, 80

PALACIO, 96, 104

PALADAR, 139

Paletoques

- de puertas enteras, 103

- de medias puertas, 103

PaLOMAS, 28

PAN, 47, 89, 116

- bazo, 76

PAÑo/s, 84, 96, 98, 103, 104, 146, 152

- áspero, 146

- de colores, 64

- fino, 94, 96, 108

- honestos, 64

- grueso, 154

- menores, 47

- vil, 64, 154

Paraíso Terrenal, 51 , vid. cielo

PARDILLO, 103

PARTE/S

- del cuerpo, 52

- vergonzosas, 47

Partiduras de las cabelleras, 130

PARTO, 145

PASCUA, 112

PASTORES, 98

- eclesiásticos, 28

PatRIARCA, 58, 77, 86, 120, 165

PAZ, 77, 78, 80, 124

- temporal, 124

PeCADO, 1, 9, 13, 15, 16a, 17, 18, 28, $29,41,52,61,64,78,84,90,91-93$, $101-104,109,115,117-120,123-$ $125,131,134,135,139,144,145$, $147-149,153,158,161,162$

- contrario a la humildad, 14

- de ambición, 103

- de avaricia, 14, 87, 89, 91

- de deleite, 96

- de disolución, 103

- de homicidio, 32

- de lujuria, 103

- de mentira, 84

- de mollicie, 96

- de obra, 158

- de palabra, 158
- de prodigalidad, 103

- de rapiña, 14, 87, 89, 91, 103

- de soberbia, 14, 84, 87, 88, 95, 103

- de tiempo perdido, 103

- de vanidad, 103

- grave, 143 (nota, 290), 160, 161, 165,166

- original, 47,48

- mortal, 22, 23, 42, 67, 134, 136$140,143,144,159,161,166$

- venial, $23,67,138,140,143,158$, 160

PeCAdoR/ES, 49, 134, 172

- excomulgado, 134

Peces, 156

Pechos, 52, 103, 104

- descubiertos, 52

- estrechos, 155

Pellejas, 98

Pellotes, 103

PENA/S, 120, 135, 142, 144, 165, 169

- civiles, 125

- criminales, 125

- de destierro, 36

- de excomunión, 21, 36, 133, 134, 136,144

- mayor, 162

- de muerte, 29

- pecuniaria, 36

- temporal, 136

Pendientes, vid. zarzillos

Penitencia, 28, 64, 72, 77, 112, 114, 120,124

Pensamientos, 28, 117

PEÑA, 94, 104

PEPINOS, 118

Pequeñeza, 139

Percha, 86

Perdiz, 77, 116

Perdón, 112, 171

PerJuICIO, 159

Perlas, 100, 130

Peros reales, 74, vid. manzanas

PERRo, 77, 80, vid. podenco

Persona/s, 4, 27, 36, 37, 40, 67, 84, 85, $88,89,93,103,104,106,116,119$, 
$120,134,136,145,146,157,162$, 163,171

- cruel, 147

- curiosas, 144

- deshonestas, 119, 147

- diversas, 71

- de estado seglar, 103

- de todos los estados, 94

- del hijo, 20, 126

- eclesiásticas, 55

- livianas, 119

- maliciosas, 144

- que excede de lo natural, 160

- real, 103

- soberbias, 95

Pescado, 156

PIEDAD, 163

Piedras, 104

- preciosas, 130

PIELES, vid. peña

- de animales, 98

- del tabernáculo, 103

Piernas, 55, 148-150, 154

PIES, 55, 104

PIMIENTA, 146

PINTOR, 163

PINTURA, 108

PIPAS, 155

Placer, 95

PLANCHAS

- de plomo, 146

Plata, 89, 166

Plaza, 169

Pliegues, 156

- en las caderas, 103

Plomo, 146

Pluvia, vid. lluvia

Pobreza, 81, 124

PODENCO, 77

Poden, 27, 30, 34, 78, 89 ,

- del demonio, 134

- del diablo, 135

- infinito, 33

Poetas, 156

POLLO/S, 74, 116

Polvo, 55
Pontífices, 142

Potajes, 16a, 101

Pozo, 170

Práctica, 16a, 16b, 38, 101, 104

Precio, 118

Predestinados, 49

Predicadores, 169

Preguntadores, 30

Prelado/s, 19, 27, 28, 30, 34, 121-123, $125,144,152,153,166$

- buenos y honestos, 31

- eclesiásticos, 21, 36, 122, 133, 134, $136,141,142,144,165$

- malos y deshonestos, 31

- santos, 97

- seglares, 122, 141, 142, 165

PREsunCión, 139

Presupuesto, 145

Primogénito, 117

Príncipe/s, 103, 110, 113, 124

- de Siria, 86

Prior, 1

Prodigalidad, 103, 139

Profeta, 51, 52, 60, 61, 76, 86, 104, $107,112,113,120,127,157$

PROPORCIÓN

- de cuerpo, 163

- natural, 156

PROSPERIDAD, 63

PROVISORES, 144, 167

- venerables, 36 (nota 47)

Prudencia, 139

PSALMo, vid. salmo

Pueblo/s, 1, 2, 26, 27, 60, 64, 103, 122 , $127,166,169$

- cristiano, 80

- de Israel, 20, 112, 126

- duro de cerviz, 32

Puerros, 118

PuERTA/S

1. del templo, 113

2. (indumentaria), 103

Puñales, 103

Puñetes, 103, vid. mangas

Púrpura, 68, 100

Pusilanimidad, 139 
$\mathbf{Q}$

QUATROPEAS, vid. cuadrúpedas

$\mathbf{R}$

RALEA, 77

RAPIÑA, 14, 87, 89, 91, 103

REBAÑos, 156

REBEZO, 84

RECIBIMIENTO, 156

RECTORES, 125, vid. regidores

REDONDELES, 104

REFECCIÓN, 134

REgatonas, 154

REGIDORES, 19, 27, 122, 144, 152, vid. rectores

REgIMIENTO, 144

REgLA, 68, 130, 139

- en el vestir, 41, 165

- general, 103, 139

REINA, 107

- de Saba, 106

- de los ángeles, 38

- de los cielos, 38 (nota, 52)

Reino, 43, 100, 103, 165, 166, 169

RELIGIÓN/ES, 169

- de los caballeros, 64

- santas, 80

- de los ángeles, 38

Religiosos, 64, 76

REMEdIO, 142, 146

RENES, 155

RePÚBLICA, 124, 141, 152

RESURRECCIÓN, 49

REY, 34, 76, 96, 100, 103, 106, 107,

$111,126,156$

- mozo, 110

- soberano, 38

$\mathrm{R} / \mathrm{co} / \mathrm{s}, 124$

- malaventurado, 68, 100, 120, 129

RIÑNES, vid. renes.

RIQUEZA/s, 12, 124

Roso, vid. bermejo, colorado
Ropa/s 85,89 , vid. hábito, vestimenta, vestido, vestidura

- corta, 55, 93, 103

- deshonesta, 103

- justa, 93

- larga, 55, 93, 103

- mesurada, 93

- rozagantes, 103

Rosa, 106

ROSTRO, 163

RUEDA de molino, 149

$\mathbf{S}$

SÁBADO, 32, 34, 128

SÁBANAS, 103

SABIO/S, 47, 55, 106, 139, 146

- eclesiástico, 69, 118

- grandes, 123, 124

SABORES, 128

SACERDOTE, 98, 103, 108, 142

- mayor, 98

SACo/s de sayal, 64

SACRAMENTOS, 78, 80

SACRIFICIO, 113

SACRILEGIO, 163

Sagrada Escritura, 47, 52, 64, 106, $110,118,119$

SAL, 146

SALMO, 52, 76, 120

SALMOREJO, 102

SALSA, 146

SANGRE, 32

- humana, 32

SAN/TO, $20,27,31,38,48,49,51,58$, $76,88,89,96,100,103,107,129$ $131,135,155,156,162$, vid. apóstoles, caballeros, doctores, prelados, varón

SARDINA, 146

SARTALES, 52, 104

SASTRES, 36

SAYA, 52, 84, 98, 108, 154

- morada, 108

SAYAL, 64, 146 
SAYO, 84,103

$$
\text { - viejo, } 94
$$

SAYUELA, 103

SECA, vid. sequía

SED, 116, 118

SEDA/S, 64, 66, 84, 94, 96, 103, 104, 130

SEGADORES, 98

SEGLAR/ES, $55,61,103,122,123,141$, 142 , vid. prelados

SemejanzA, 68, 79, 106, 111, 114, 156

SENO, 52

Sentencia, 122, 163

- de excomunión, 36

- de sabio eclesiástico, 69

SENTIDO, 116

- del oír, 139

SEÑUELO, 170 (nota, 354)

SEQUIA, 171

SERBAS, 74

SERENA, vid. sirena

SERPIENTE/S

1. La, 37

2. $28,29,37$

SERVICIA, 75

SeRvicios, 154

SERVIDORES, 106

SERVILLAS, 84

SESO, 55

SIDRA, 75

SIERVAS, 154

SIMPLEZA, 88, 142

- natural, 103

- de las vestiduras y viandas, 129

SIMULACIÓN, 158

SIRENA, 156

SOBERBIA, $14,84,87,88,93,95,100$, 103, 139, 160

SOBRESAYA, 84

SOBRIEDAD, 88

SOLEMNIDAD, 110

SOLETA, 103

SOMBRERO/s, 84 , vid. capello

- de fieltro, 103

- de ruedo pequeño, 103

- de ruedo grande, 103

- negros, 103
- pardillos, 103

- pelados, 103

SúBDITOS, 2, 26, 27, 125

- religiosos, 153

SUDARIO, 103

SUFICIENCIA, 88, 99

SUFRAGIOS espirituales, 134

$\mathbf{T}$

TABARDOS, 103, 104

- de lino, 104

- de paño, 104

- de peña, 104

- de seda, 104

TABERNÁCULO, 103

TALLADOR, 163

TASAS (indumentaria), 103

TAU, 78

TEJILLOS, 104

TELA, 84

TEMERIDAD, 139

TEMOR, 136

TEMPERAMIENTO, 51 (nota, 71)

TeMPERANZA, 51, vid. templanza

TEMPLANZA, 114, 163, vid. temperanza y temperamiento

TEMPLO, 30, 103, 113

TETAS, 52, 75

TEXTO, EL, 47 (nota 61) , 58, 98

TIEMPO

- debido, 83

- de adversidad, 63, 72

- de aflicción, 64, 72, 77

- de alegria, 63, 110

- de consolación, 112

- de esterilidad, 72, 81

- de Galícano, 96

- de gozo, 63

- de invierno, 151

- de lloro, 63, 110

- de mengua, 72

- de penitencia, $64,72,77,114$

- de perdón, 112

- de pobreza, 81 
- de prosperidad, 63

- de tribulación, 110

- de tristeza, 63

- del cerco de Samaria, 97

- del diluvio, 77, 165

- diversos, 71

- frío, 72

- honesto, 103

- perdido, 103

TIERRA/S, 74, 75

- bermeja, 48

- cenagosa, vid. cenosa

- cenosa, 48

- frías, 108

- limosa, 48

- virgen, 48

TOCA, 52

TOCADO, 84 , vid. tocas

TOCAS, vid. tocado

- con lienzo en el tocado, 84

- con moños, 104

- con vueltas, 104

- cortas, 104

- crepadas, 104

- de lino, 104

- de seda, 104

- encrespadas, 104

- espumillas, 104

- largas, 104

- lencarejas, 104

- llanas, 104

- sanas, 104

- sin moños, 104

- tambas, 104

TOGA, 98

TONELES, 155

TONGA, vid. toga

TORMENTO INFERNAL, 120

Traje/s, 4, 16a, 18-20, 23, 40, 41, 101,

$115,121,122,125,126,134,136$,

143,166

- dañoso, 145

- de mujeres, 132

- deshonestos, 36, 131, 170

- desvergonzado, 132

- excomulgado, 19, 23, 143, 167
- impúdico, 132

- livianos, 131

- maldito, 165,170

- nocivo, 145

- nuevos, 119

- supérfluo, 132

TRAPOS, 158, 161

TRASPASADORES de penas, 125

Tratado, 1, 3, 25, 26, 35, 44, 168, 169 , 171

TRENCHA, 104, 130

TRENZA, 127

TRIBULACIÓN, 110, 124

TRINIDAD, SANTA, 78, 79

TRIPERAS, 154

TRISTEZA, 63, 114

TRIUNFF, 106

TúNICA/S,

- cintadas, 98

- con cotes de garras en las orillas, 98

- de abortones, 98

- de corderinas, 98

- de pellejas, 98

- forradas, 98

- guarnecidas de baldreses, 98

- jacintinas, 103

$\mathbf{U}$

UNIVERSIDAD, 169

UÑAS, 156

Uso/s, 41

- común, 59, 119, 148

- de los sacerdotes, 108

- universal, 148

- viles, 154

ÚTERO, vid. madre 2.

V

VACAS, 74, 156

VANAGLORIA, 88, 95, 100, 119

VANIDAD, 52, 100, 103, 131

VARA (medida), 84 
VARÓN/ES, 6, 7, 16a, 36, 37 (nota 51), $39,52-57,59,60,71,84,101,103$, $119,127,149,155,160$

- mayores, 103

- menores, 103

- prudente y sabio, 139-141, 144

- santos, 76

VENADO, 103

VENGANZA, 120

VENTOSIDAD, 139

VERANO, 63, 72, 74, 85, 151

VERDAD, 141

VERDE, 72, 74, 103, 166

Verdugos, 19, 23, 36, 121, 143, 144, $155,161,162,167$

VERGÜENZAVS

- partes vergonzosas, 47, 52, 103, vid. partes vergonzosas

- vergüenza, 48, 49, 52, 55, 104 (nota 204)

VESTIDO, 54, 80, 85 (nota, 151), 91, 100, vid. hábito, vestidura, vestimenta

VESTIDURA/s, 8, 16a, 47, 52, 62, 64, 66, $84,86,89,91,98,101,104,105,129$

- abiertas, 166

- ásperas, 96, 97

- bermeja, 166, vid. colorada

- blandas, 96

- clerical, 166

- colorada, 106 (nota, 210)

- cortas, 166

- costosas, 107

- cotidianas, 110

- de adversidad, 63

- de alegria, 63, 110, 111

- de boda, 111

- de colores, 108

- de cotidiano, 85

- de fiesta, 85, 112

- de gozo, 63

- de grana, 100

- de lloro, 63

- de monjes, 97

- de mujer, 127

- de oro, 130

- de perlas y piedras preciosas, 130
- de placer, 112

- de prosperidad, 63

- de Salomón, 106

- de seda, 130

- de solemnidad, 110

- de tristeza, 63, 110 ,

- de varón, 127

- de verano e invierno, 63, 85

- de los ministros, 106

- deforme, monstruosa y peregrina, 156,157

- doblada, 106

- espiritual, 49

- hechas a mitades, 166

- largas, 107, 166

- linda, 106, (nota 210)

- muelles, 96

- necesarias, 50, 51

- partidas, 166

- plegada, 66

- preciosas, 100, 106, 107, 120

- que llevan a Misa, 85

- real, 97, 100

- sin pliegues

- sobradas, 127

- solemne, 111

- tristes, 112

- verdes, 166

VEstIMENTAS

- de lino, 98

- de paño, 98

VIANDA/S, 75, 77, 116, 128, 129

- adobadas, 83, 102

- asada, 116

- cocida, 116

- comunes, 102

- costosas, 76, 83, 93, 102

- de poco precio, 102

- delgadas, 72

- delicadas, 71

- desabridas, 72

- despreciadas, 81, 83

- exquisitas, 83

- gruesas, 71,72

- guisadas, 102

- pobres, 72 
- recias, 71,74

- sabrosas, 76

- sutiles, 71

- vedadas, 110

VICIO, 103, 160

VICTORIA, 111

VIDA, 76, 135, 165, 169

- corporal, 149

- humana, 47

VIEJO, EL, 71

V'IENTO, 151

VIENTRE/S, 52, 117, 146, 151

- anchos y gruesos, 155

- escalentados, 151

- virginal, 48

VIERNES, 112, 128

VILLA, 1, 25, 36, 100, 167-170

VILLANO, 94, 112

VINO/S, 75, 116

- costosos, 93

VIÑA, 75

VIRGEN, 38

VIRGEZ, 38

VIRGINIDAD, vid. virgez

VIRTUD/ES, 14, 48, 49, 75, 87, 88, 99, $106,120,134,138,139,169$

VIso, vid. bisso

VISPERAS, 85

VISTA

- clara, 139

- de las piernas, 149

- mala, 139

- sana, 139

VITO, 100

VIUDAS, 145

VOLUNTAD, 165, 171

- del demonio, 134

- del marido, 153
- del prelado, 153

- desordenada, 165

$\mathbf{Y}$

YERRO, 12, 146, 171

$\mathbf{Z}$

ZAMARRO, 84

ZANCAJOS, 148

ZAPATERÍA, 131

ZAPATOS, 84

- abiertos, 103

- blancos, 103

- cerrados, 103

- con caireles

- de aro, 103

- de seda labrados, 103

- con puertas, 103

- de colores, 103

- de cuerda, 103

- de muchos lazos, 103

- de punta larga, 103

- con galochas, 103

- sin galochas, 103

- de un lazo, 103

- de venado, 103

- romas

- con alcorques, 103

- sin alcorques, 103

- sin puertas, 103

ZARZILLOS, vid. cercillos

ZuECOS, 84, 104, 131 


\section{INDICE DE PERSONAS}

ABINICIO, 148

ABRAHAM, patriarca, 120, 165

ABSALÓN, 111

ACHOF, 100

ADÁN, 48

ADÁN II, apóstol, 48

AGAB, rey, 100

AGUstín, San, 100

Ambrosio, San, 90

BARUCH, profeta, 60

BASILIO, San, 89

CAIN, 135

Cecilia, Santa, 96

Cipriano, obispo, 162

Crisóstomo, San, 11, 162

DANIEL, santo y profeta, 76

DAVID, rey, santo y profeta, 107, 111

ELIAS, profeta, 51

ELISEO DE NAAMAN, profeta, príncipe de Siria, 86

ENRIQUE IV, rey (de Castilla), 103

ESAÚ, 86, 117

ESTHER, reina, 107

Eva, 29

EZEQUIEL, profeta, 61, 104, 113

Galícano, 96

GEDEON, juez, duque, caudillo y capitán, 118

Hernando de Talavera, Fray, 1

HERODES, 100

ISAAC, patriarca, padre de Jacob, marido de Rebeca, 58, 86

ISABEL I, reina de España, 1
ISAIAS, profeta, 80, 104, 127

ISIDORO, 103, 155, 156

IsIDRo, San, vid. Isidoro

JACOB, hermano de Esaú, 86, 117

JERÓNIMO, San, 162

JESUCRISTO, 27-30, 343, 48, 68, 78, 91 , 118,129

JOAB, condestable, 111

JOB, Santo, 81, 135

JORÁN, rey, 97

JUAN, San, 49, 96, 100, 129

JUDITH, Santa y dueña, 96

LOTH, 165

LUCAS, San, evangelista, 100

MARINA, Santa, 156

MARTín, San, 96

MoIsÉs, Santo, 32, 120

NOÉ, patriarca, $75,77,78$

PABLO, San, apóstol, 96, 100, 10, 135

Pedro, San, apóstol, 31, 100, 130

Platón, filósofo, 131

RebecA, Santa, 58, 86

SALOMÓN, sabio, 34, 106

SATANás, 78, 135

SAÚL, rey, 100

Sebastián, San, 96

SOFONIAS, 157

Talavera, Hernando de, vid. Hernando de Talavera

Tobías, santo, 81

Tomás, San, obispo de Canturia, 97

TOMÁS DE AQUINO, Santo, doctor moderno, 132 